ECONOMIC ANALYSIS OF WOODY BIOMASS HARVESTING

IN THE MISSOURI OZARKS

A Thesis presented to

The Faculty of the Graduate School

University of Missouri

In Partial Fulfillment

of the Requirement for the Degree

Master of Science

by

ADAM M. SAUNDERS

Dr. Francisco X. Aguilar, Thesis Supervisor

JULY 2010 
The undersigned, appointed by the Dean of the Graduate School, have examined the thesis entitled

\section{ECONOMIC ANALYSIS OF WOODY BIOMASS HARVESTING}

\section{IN THE MISSOURI OZARKS}

presented by Adam M. Saunders

a candidate for the degree of Master of Science, and hereby certify that in their opinion it is worthy of acceptance.

Assistant Professor Francisco X. Aguilar

Associate Professor John P. Dwyer

Associate Professor H.E. "Hank” Stelzer

Professor and Curators Distinguished Teaching Professor J. Sanford "Sandy" Rikoon 


\section{ACKNOWLEDGEMENTS}

Giving thanks early and often is one of the keys to a healthy and prosperous life. There are many people who I owe great thanks to for their support, guidance and help in writing this thesis. Furthermore, thanks are owed to the people who helped guide me to be in a position to complete a college degree and now a post-graduate Masters degree. First of all I thank my parents, Andrew and Laurie Saunders. Your love and encouragement from a young age has instilled the drive to achieve and challenge myself to improve my weaknesses. Your land ethic and kindness has also been a guiding force that motivates me to strive to make positive impacts in my community and the world. I have been truly blessed to have parents like you.

A special thanks goes to Dr. Francisco X. Aguilar for his role as my major advisor during my Masters project. Your work ethic, critical thought and teaching ability is truly inspiring and pushes me to work even harder. Thanks are also due to my committee members, Dr. John P. Dwyer and Dr. Hank Stelzer, for their help setting up the field study, advising me during the study harvest and coaching me through the report writing process. Many thanks are owed to my committee member Dr. Sandy Rikoon for his help reviewing the thesis drafts. Thank you to Charlie Hansen for being a great research partner in this study. Thank you to the Missouri Department of Conservation and the local staff, Mark Pelton, Ronny Cummins, and Johnny Tuttle for access to a beautiful study site and for countless insights into the world of industrial forestry and conservation forestry. Your knowledge added considerable depth to this process. 


\section{Table of Contents}

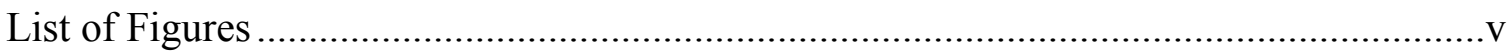

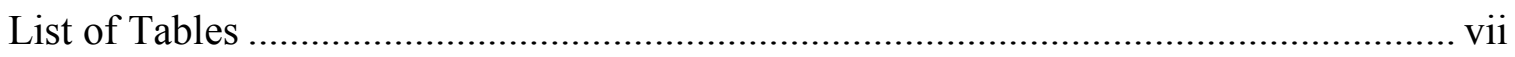

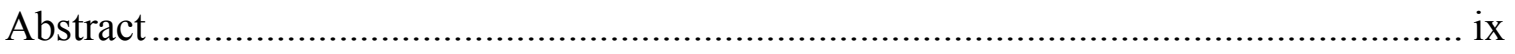

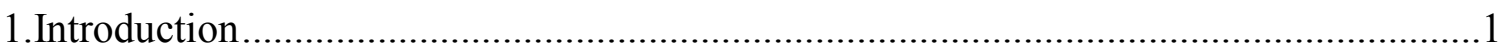

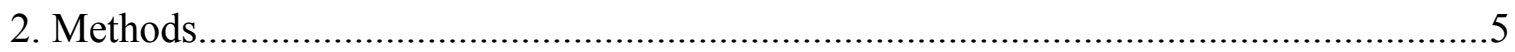

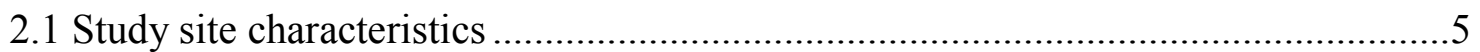

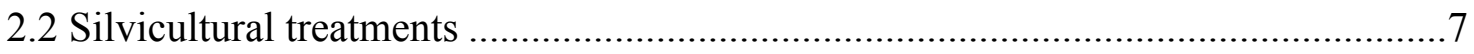

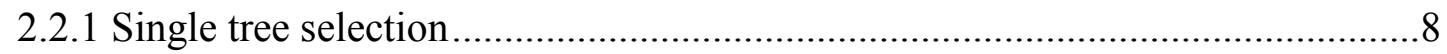

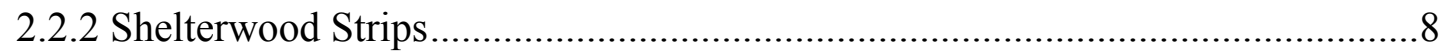

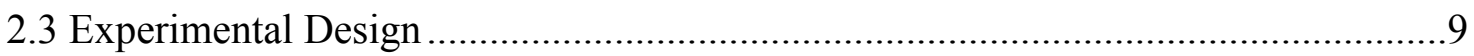

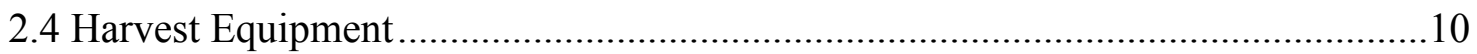

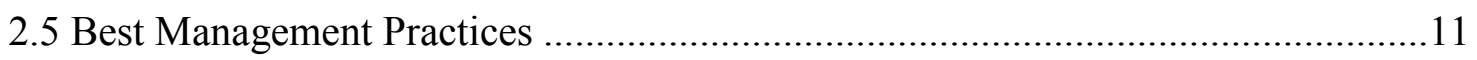

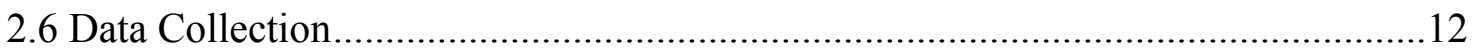

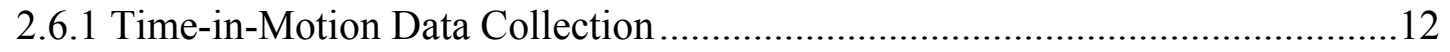

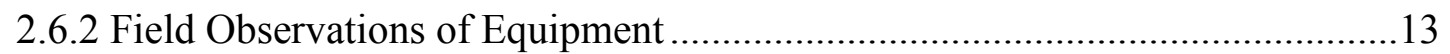

2.6.3 Estimating Yields and Revenues ...............................................................16

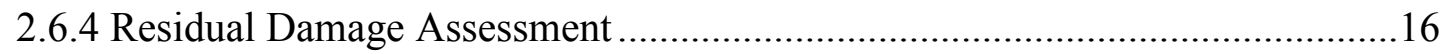

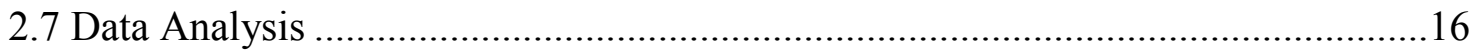

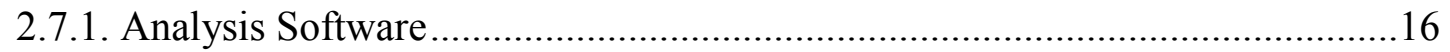

2.7.2 Fixed Equipment Cost Estimation..................................................................17

2.7.3 Variable Equipment Costs Estimation..............................................................19

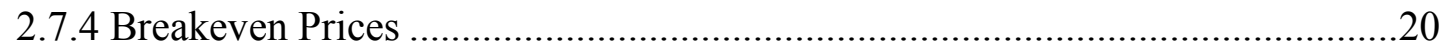

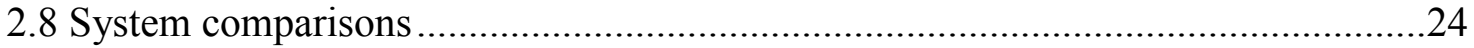

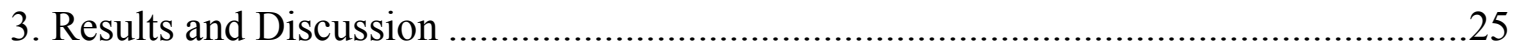

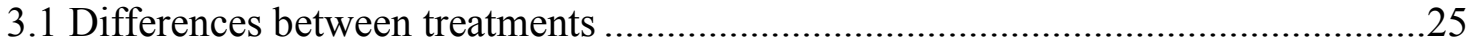

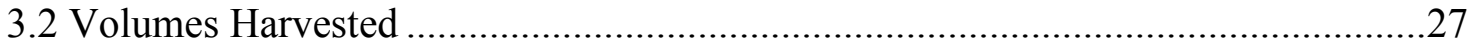

3.3 Prices Observed for SHWP and Fuel Chip Products ..............................................30

3.4 Field Observed Productivity ............................................................................

3.5 Observed System Costs ...................................................................................

3.5.1 Fixed Equipment Costs.................................................................................

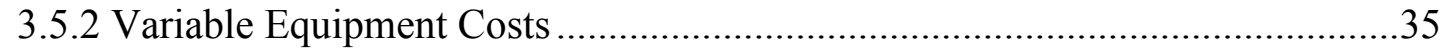

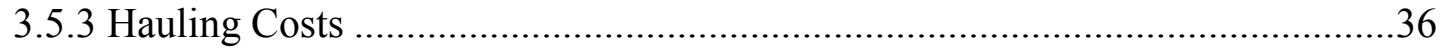




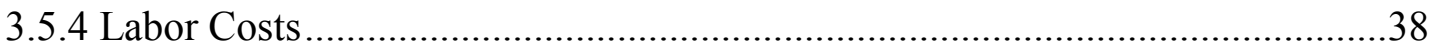

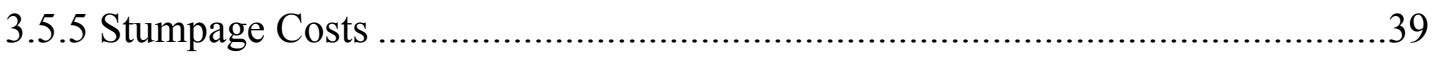

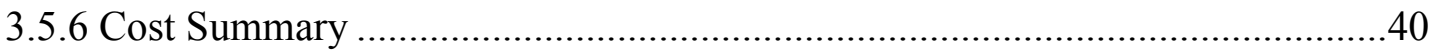

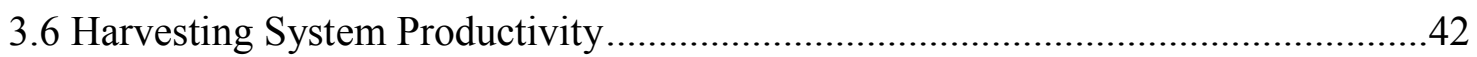

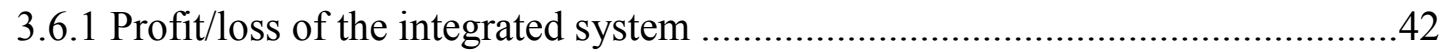

3.6.2 Profit/loss of the "merchantable system" .........................................................4

3.6.3 Differences between integrated and merchantable systems ..............................45

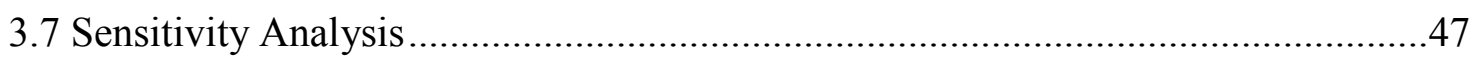

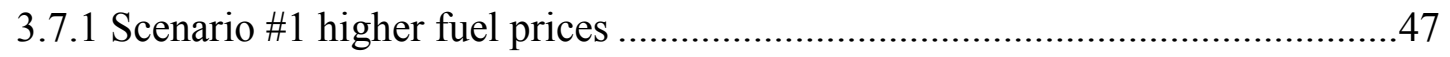

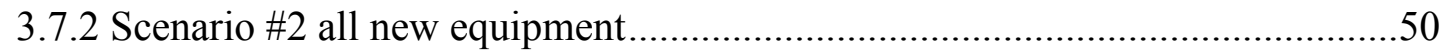

3.7.3 Scenario \#3 changes in hauling distances..................................................52

3.7.4 Scenario \#4 changing stumpage costs ........................................................54

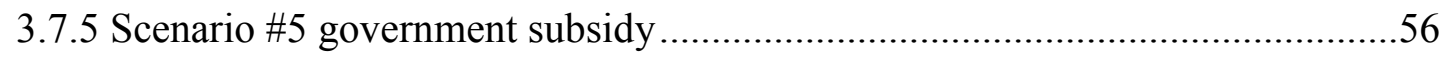

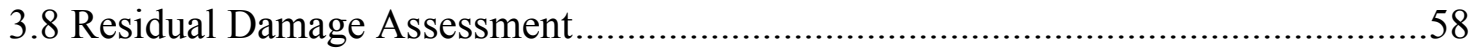

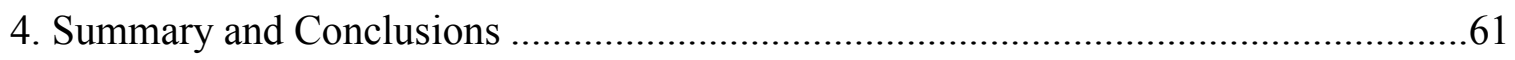

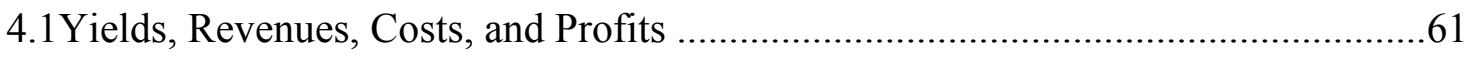

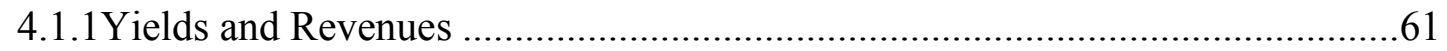

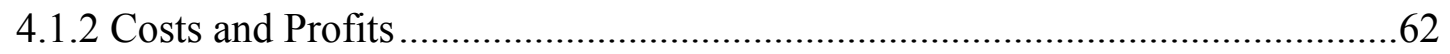

4.1.3 Comparisons to other integrated harvests .....................................................64

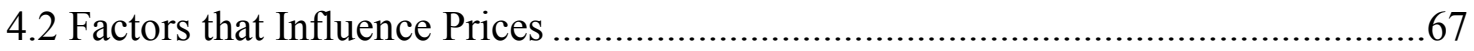

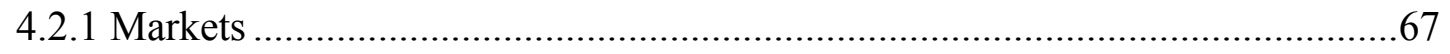

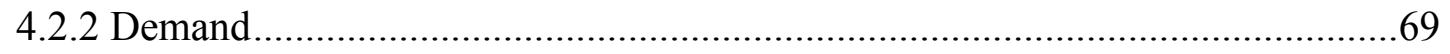

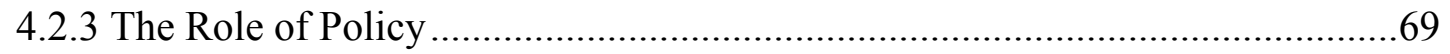

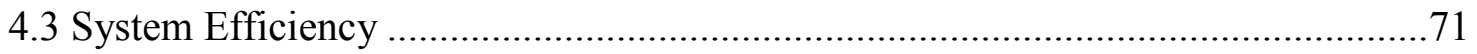

4.3.1 System Efficiency: Bottlenecks ....................................................................71

4.3.2 System Efficiency: Treatment …………………......................................73

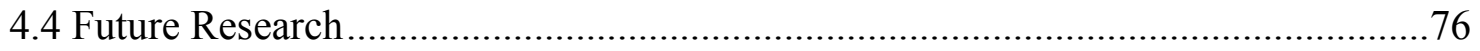

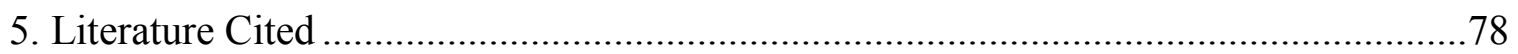

Appendix A: Study summary using seven themes identified by Evans (2008).................84

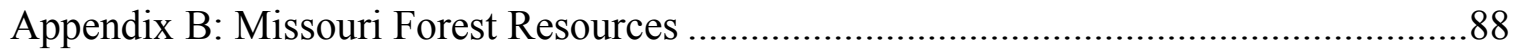

Appendix C: Sample Yellow Activity Monitoring System data sheet .............................92

Appendix D: Skidder Cycle time regression analysis and data sheet ...............................93 


\section{List of Figures}

Figure 1. Map of harvest study site in Butler County, Missouri.......................................5

Figure 2. Pre-treatment trees per acre for the eight most abundant species and pooled trees per acre for the ten least abundant species.

Figure 3. Pre-treatment diameter distribution of the trees per acre

Figure 4. Schematic map of sample plot layout $(\mathrm{R}=$ replication number and $\mathrm{P}=$ plot number). Square plots are 3 acres, either single tree selection or control. Narrow plots are shelterwood strips, either 75 feet or 150 feet in width and approximately 450 feet long.

Figure 5. Yellow Activity Monitoring System data collector "Yellow Box" attached to skidder

Figure 6. Average tons per acre removed by treatment

Figure 7. Pre and post basal area per acre for the five treatment designs

Figure 8. Pre and post treatment basal area for the eight most abundant over story species. The ten least abundant are pooled as "Others".

Figure 9. Distribution of observed solid hardwood product prices per ton ......................32

Figure 10. Loader activity sampling observed breakdown between five main categories

Figure 11. Total observed cost components. ............................................................41

Figure 12. Integrated system costs per ton for each component of the harvest ................42

Figure 13. Cost of all components assuming that only the solid hardwood products were harvested, "merchantable system".

Figure 14. Comparison of the Integrated System's and Merchantable System's cost, revenue, and profit per ton for harvested products.

Figure 15. Effects on system cost, revenue, and profit/loss (cost per acre) of harvesting the "Integrated system" (solid hardwood products and fuel chips) and the "Merchantable system" (solid hardwood products only). The third column labeled "Change" shows the difference between these two systems.

Figure 16. Sensitivity analysis of the total production cost per ton to increases in diesel fuel. Cost components include harvesting, labor, hauling (assumed 100 mile round trip), and stumpage at $\$ 9.95 /$ ton and $\$ 5.00 /$ ton for the solid hardwood products and fuel chips respectively.

Figure 17. Sensitivity analysis of the total production cost per ton to increases in the equipment suite total purchase prices. Cost components include harvesting, labor, hauling (assumed 100 mile round trip), and stumpage at $\$ 9.95 /$ ton and $\$ 5.00 /$ ton for the solid hardwood products and fuel chips respectively. This analysis assumes fuel price of $\$ 2.50$ per gallon of offroad diesel.

Figure 18. Sensitivity analysis of the total production cost per ton to changes to the roundtrip hauling distance. Cost components include harvesting, labor, hauling, and stumpage at $\$ 9.95 /$ ton and $\$ 5.00 /$ ton for the solid hardwood products and fuel chips respectively. This analysis assumed fuel price of $\$ 2.50$ per gallon of off-road diesel. 
Figure 19. Sensitivity analysis of total production cost per ton to change to the stumpage cost paid for SWHP. Other cost components held constant include harvesting, labor, and hauling. This analysis assumes a fuel price of $\$ 2.50$ per gallon of off-road diesel.

Figure 20. Sensitivity analysis of total production cost per ton to change to the stumpage cost paid for fuel chips. Other cost components held constant include harvesting, labor, and hauling. This analysis assumes a fuel price of $\$ 2.50$ per gallon of off-road diesel.

Figure 21. Marked leave tree that received skidding damage during harvest. An estimated 25 percent of residual trees in the harvested area experienced some kind of harvest damage.

Figure 22. Average residual damage observed by treatment. No significant differences were detected between the treatment means. ....

Figure 23. Average cycle times for different observed skid distances between 60 feet and 2,353 feet.

Figure 24. Frequency of skid distances observed during study harvest. 


\section{List of Tables}

Table 1. Seven themes identified by Evans (2008) present in woody biomass study harvests.

Table 2. Treatment list with actual acreage ............................................................ 9

Table 3. Assumed hauling speeds for different road types ...........................................15

Table 4. Equipment utilized in study harvest and the factors influencing the cost of ownership, the cost per scheduled mechanized hour......................................18

Table 5. Equipment utilized in study harvest and the factors influencing cost of operation, cost per productive mechanized hour ....

Table 6. Treatment mean comparisons of tons per acre removed. $P$-values less than 0.05 indicated significant differences.

Table 7. Mean productivity of PMH per acre and Tons harvested per PMH for both the shelterwood strip (SW) treatment and the single tree selection treatment (STS). P-values indicate that there is no difference in the observed means.

Table 8. Total ton per acre, tons per acre, and solid hardwood product tons per acre removed from each sample plot.

Table 9. Solid hardwood product and fuel chips price results for the nine different product buyers observed in this study and the hauling distance to each of these buyers

Table 10. Fixed equipment cost figures showing the cost per scheduled mechanized hour, observed scheduled mechanized hours, fixed equipment cost for each piece and the entire equipment suite.....

Table 11. Estimation of the fixed equipment cost per ton for solid hardwood products and fuel chips.

Table 12. Variable equipment cost figures showing observed number of productive hours $(\mathrm{PMH})$, cost per productive mechanized hour, variable equipment costs for each piece and the entire equipment suite.

Table 13. Estimation of the variable costs per ton for both solid hardwood products and fuel chips.

Table 14. Distance to mills by road type, estimated round trip hauling time, and average speed.

Table 15. List of observed variable, fixed and total costs for equipment, stumpage and labor.

Table 16. Estimated cost per ton for each component of the study harvest for both solid hardwood products and fuel chips.

Table 17. Summary of costs observed during the integrated system study harvest.

Table 18. Balance sheet for the integrated system that shows the profit/loss per ton and the net revenue

Table 19. Merchantable system estimated variable equipment cost and production rates

Table 20. Balance sheet of the Merchantable System showing this profit per ton and the net profits of this assumed system.

Table 21. Balance sheet of integrated system with the BCAP matching subsidy added to the fuel chips. 
Table 22. Mean comparison of residual damage between treatment designs.

Table 23. Comparison of the revenues, costs, and profit/loss of the Integrated and the Merchantable Harvest System.

Table 24. Cost estimates for seven integrated harvest systems complied by Puttock (1995). Cost estimates do not include stumpage or hauling costs. System estimates A-G not adjusted for inflation between 1995 and 2010.

Table 25. Total cost of production for solid hardwood products and fuel chips for seven integrated harvest systems. Cost estimates do not include stumpage or hauling costs. System estimates A-G not adjusted for inflation between 1995 and 2010.

Table 26. Over story species observed in study site and estimated lifespan in the Missouri, Ozarks environment.

Table 27. Parameter Estimates for skidder regression analysis. Three parameters (intercept, distance, and delay) were observed to be significant in predicting cycle time. 


\title{
Economic Analysis of Woody Biomass Harvesting in the Missouri Ozarks
}

\begin{abstract}
An integrated mechanized timber harvest thinning treatment to remove small diameter trees and merchantable saw logs was conducted on 30 acres of the Missouri, Ozarks in the summer of 2009. Two silvicultural treatments (single tree selection and shelterwood strips) were applied to reduce basal area to different levels. A harvest system feasibility analysis was completed to estimate productivity, costs, and prices needed to attain economic viability (breakeven point). Time in motion data was collected on all system components to understand how the extra efforts to gather small diameter and slash material affect the cost structure of a mechanized timber harvest thinning. A sensitivity analysis was conducted to find breakeven points at varying diesel input costs, equipment purchase costs, hauling distances, stumpage costs and government subsidy. Results indicate that an average of 15.50 tons of fuel chips and 35.72 tons of solid hardwood products was removed per acre. The cost per ton to harvest, skid and process at road side for the fuel chips and solid hardwood products was $\$ 19.20$ and $\$ 11.17$ per ton respectively. Contracted fuel chips hauling cost was $\$ 12.00$ per ton and solid hardwood hauling averaged $\$ 4.16$ per ton. Stumpage was assumed to be $\$ 5.00$ and $\$ 9.95$ per ton, respectively. Average price at the gate for these two products were $\$ 26.00$ per ton and $\$ 32.64$ per ton leading to a profit/loss of $\$-10.20$ per ton and $\$ 7.36$ per ton for the fuel chips and solid hardwood products respectively. Losses from fuel chips were less than the profits from the solid hardwood products resulting in a net profit of $\$ 3,131.76$ dollars. Keywords: woody-biomass, forest thinning, integrated harvest, single tree selection, shelterwood strips, economic feasibility, sensitivity analysis
\end{abstract}




\section{Introduction}

Wood has been utilized for heating and cooking for thousands of years. Fossil evidence suggests that routine domestic use of fire began 50,000 to 100,000 years ago (Bowman et al. 2009). The invention of the steam powered engine created a way to generate mechanical power from wood. Flader's (1999) review of forestry in Missouri estimated that a single steamboat would burn between 50 to 75 cords of wood a day to navigate the Mississippi and Missouri rivers. During the energy crisis of the 1970s substantial amounts of research was completed on identifying and utilizing renewable energy sources that would reduce the United State's dependence on imported oil and gas. Wood was identified as an abundant renewable resource with the potential to provide a range of energy and chemical products (GAO 1981, Ames and Dunavent 1984). Utilization research showed the flexibility that wood has as an energy and chemical product (Zerbe 1982). Direct combustion of wood is cited as the simplest method to extract energy, however more advance energy conversion processes can be taken to create more versatile gas and liquid energy products (Howard 1979). However, economic and technical feasibility of these later options has created road blocks to their development (Howard 1979).

Research conducted in the 1970s and 1980s also led to new developments in forest management (Stokes et al. 1989). Wood to energy studies ranged from publications that showed landowners how to harvest, store, and use firewood for residential consumption to experimental timber harvests utilizing novel all-in-one equipment able to harvest, chip, and transport entire trees at very high productivity 
(Monahan and Wartluft 1980, Koch 1980). Many technological innovations resulted from this research and are widely used today. Examples include feller bunchers, forwarders, and computer modeling programs that are able to run scenarios and make predictions.

The development of economic analysis framework to assess the feasibility of harvesting systems was a critical step that provided a way to compare harvest and procurement strategies (Miyata1980, Brinker et al. 1989, Puttock 1995, Mitchell et al. 1995). Puttock utilized an economic analysis method called "joint costing" that distributes the costs of harvesting between higher value solid hardwood products and lower value fuel wood. This method yields the most accurate estimation of the cost of production (Puttock 1995) and is utilized in this study.

Since the 1970s many new methods for harvesting, collecting and processing woody biomass have been developed and tested (Howard 1979, Stokes et al. 1989). These vary from dedicated energy crop plantations that treat wood as a perennial crop to mechanized fuels reductions that remove small diameter material from a mature forest to reduce risk of wildfire (Evans 1974, USFS 2004). The economic analysis of these strategies is critical to making informed decisions and creating a sustainable supply of renewable energy. Many different studies with a wide range of objectives and local conditions were conducted and continue to be implemented to assess the economic feasibility of harvesting woody biomass (Arola and Miyata 1981, Sturos et al. 1983, Berti 1984, Stokes 1986, Puttock 1995, Bolding 2002, Kellogg and Spong 2004, Becker et al. 2006, Bolding et al. 2006, Yoshioka et al. 2006, Mitchell and Gallagher 2007, O'Neal 2007, Bolding et al. 2009). Evans 2008 evaluated 45 study harvests and evaluated them 
using seven themes of the research (Table 1 and Appendix A). This study will be compared to other similar studies in Discussion Section 4.1.3.

Table 1. Seven themes identified by Evans (2008) present in woody biomass study harvests.

\begin{tabular}{|c|c|}
\hline Objectives & $\begin{array}{c}\text { Woody biomass removal projects tend to have multiple objectives } \\
\text { such as ecological restoration, fire hazard reduction, forest-stand } \\
\text { improvement, rural community stability, employment, and habitat } \\
\text { improvement. }\end{array}$ \\
\hline Collaboration & $\begin{array}{c}\text { Collaboration, with both the interested public and contractors, is a } \\
\text { key element in successful woody biomass removal projects. }\end{array}$ \\
\hline Ecology & $\begin{array}{c}\text { Ecological concerns about biomass removal remain, but few } \\
\text { projects incorporate monitoring to allay those concerns. }\end{array}$ \\
\hline Fire & $\begin{array}{c}\text { Fire is a key element in biomass removal projects located in } \\
\text { ecosystems where fire is an important natural disturbance. }\end{array}$ \\
\hline Economics & $\begin{array}{c}\text { Although some biomass removal projects are able to generate a } \\
\text { profit or at least break even, most projects must be subsidized. } \\
\text { Contractors, utilization markets, hauling distances, and the mix of } \\
\text { removed products all affect profitability. }\end{array}$ \\
\hline Implementation & $\begin{array}{c}\text { Many biomass removals rely on hand felling and traditional } \\
\text { skidding operations, although machines designed for biomass removal } \\
\text { are beginning to move from the experimental phase to everyday } \\
\text { operations and may make future projects more efficient. }\end{array}$ \\
\hline $\begin{array}{c}\text { Regional differences in biomass utilization and objectives reflect } \\
\text { Differences }\end{array}$ & \begin{tabular}{c} 
both forest type and ownership variations across the country. \\
\hline
\end{tabular} \\
\hline
\end{tabular}

Beyond harvest economic efficiency, a great number of studies have been conducted to ascertain the environmental impacts (positive and negative) of woody biomass plantations/harvesting (Cook 2000, Updegraff et al. 2004, Bolding et al. 2005, Janowiak and Webster 2010). A complementary component of this study will track the development and growth of the regeneration cohort that establishes as a result of the harvest treatment. Regeneration data will be collected and analyzed during summer and fall of 2010 with results made available in 2011. 
The main goal of the study was to evaluate the economic feasibility of a fully mechanized integrated harvest system in the Missouri Ozarks that collects solid hardwood products (SHWP) and converts low quality hardwoods into fuel chips for biomass energy needs. Specifically objectives include:

(1) Determine the costs and productivity associated with each component of the harvest to estimate the cost of production of the two wood product types.

(2) Conduct a sensitivity analysis to identify product prices needed to breakeven at varying fuel prices, equipment costs, hauling distances, stumpage prices, and government subsidies.

This thesis is structured in the following fashion. The Methods section outlines the site, equipment, and treatments; the data collection methods for each aspect of the harvest, and the data analysis methods for each aspect of the harvest. The Results and Discussion section outlines yields, revenues, costs of all the components, and present several scenarios that affect the cost and revenues structure of the harvest system. The Summary and Conclusions section provides a brief recap of the research findings and discuss their implications. 


\section{Methods}

\subsection{Study site characteristics}

The integrated timber harvest was conducted on 30 acres of mixed oak-hickory forests in Butler County, Missouri (Figure 1). The site was located in the "flat woods" near the escarpment transition between the Ozark hills and the Mississippi flood plain. Slope of the study site ranged from 0 to 5 percent and had a northern aspect. Site index was estimated to be 65 to 70 , assumed to be slightly higher than the average Ozarks site.
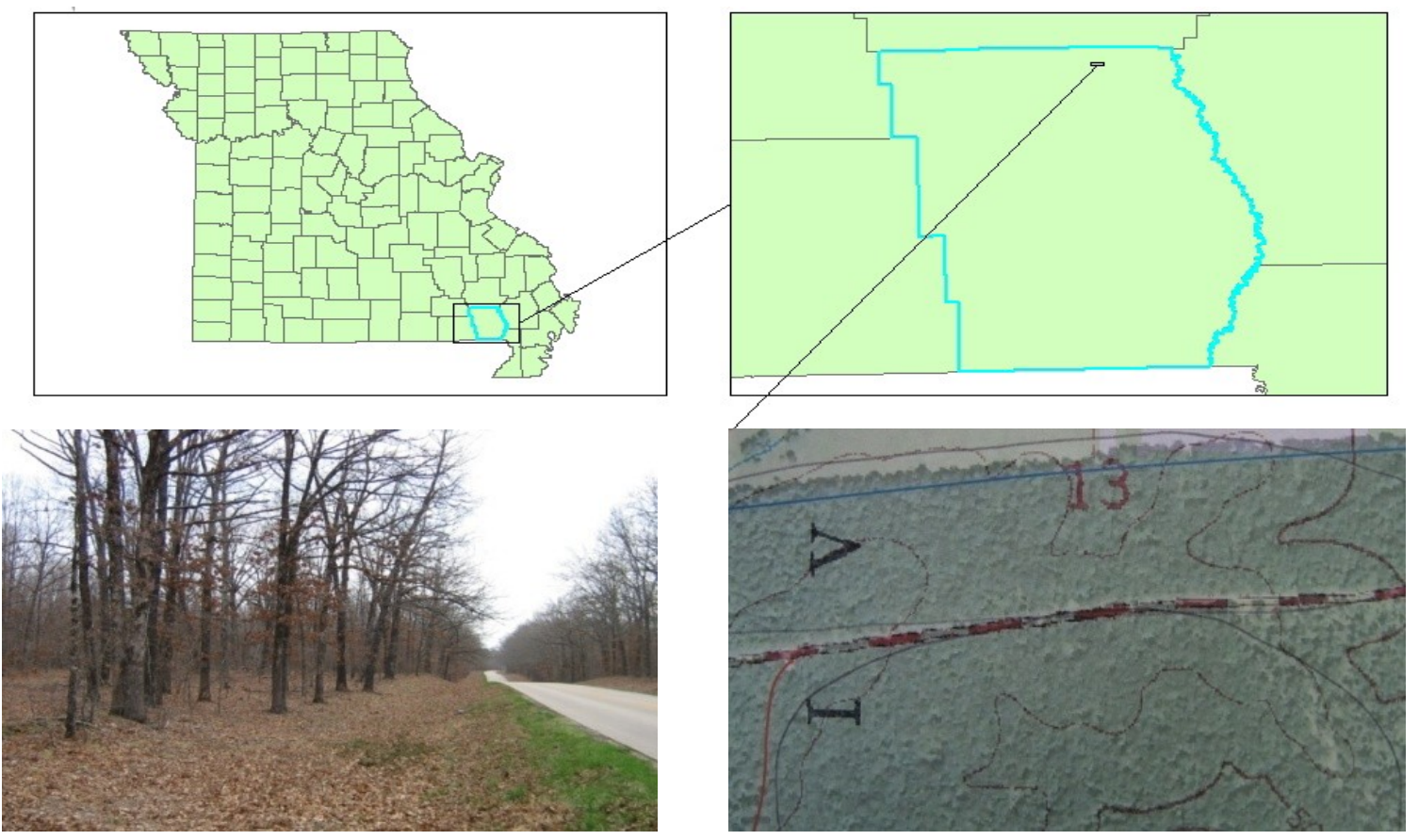

Figure 1. Map of harvest study site in Butler County, Missouri.

The over story species in the stand ranged in age from 80 to 110 years old with several small pockets of younger trees ranging between 30 to 50 years old that were a result of both old blow downs and group opening harvests that occurred in years past. The most abundant species on the harvest sites were white oak (Quercus alba), scarlet oak (Quercus coccinea), post oak (Quercus stellata), black oak (Quercus velutina), and 
southern oak (Quercus falcate) (Figure 2). Other minor species include hickory (Carya spp.), black cherry (Prunus serotina), red maple (Acer rubrum), slippery elm (Ulmus rubra), green ash (Fraxinus pennsylvanica), blackgum (Nyssa sylvatica) and sweetgum (Liquidambar styraciflua). A complete inventory of trees greater than 5 inches at breast height ( 4.5 feet above the ground) was conducted. The diameter distribution of preharvest stand conditions are presented in Figure 3. The pre-treatment basal area density for the entire site averaged 89.7 square feet and ranged from as low as 70.0 square feet and as high as 122.6 square feet. A more complete analysis of the pre-treatment stand conditions will be presented in the Results section. A review of the ecological, geological and historical management of the Ozarks region and its impact on the current forest conditions is included in Appendix B.

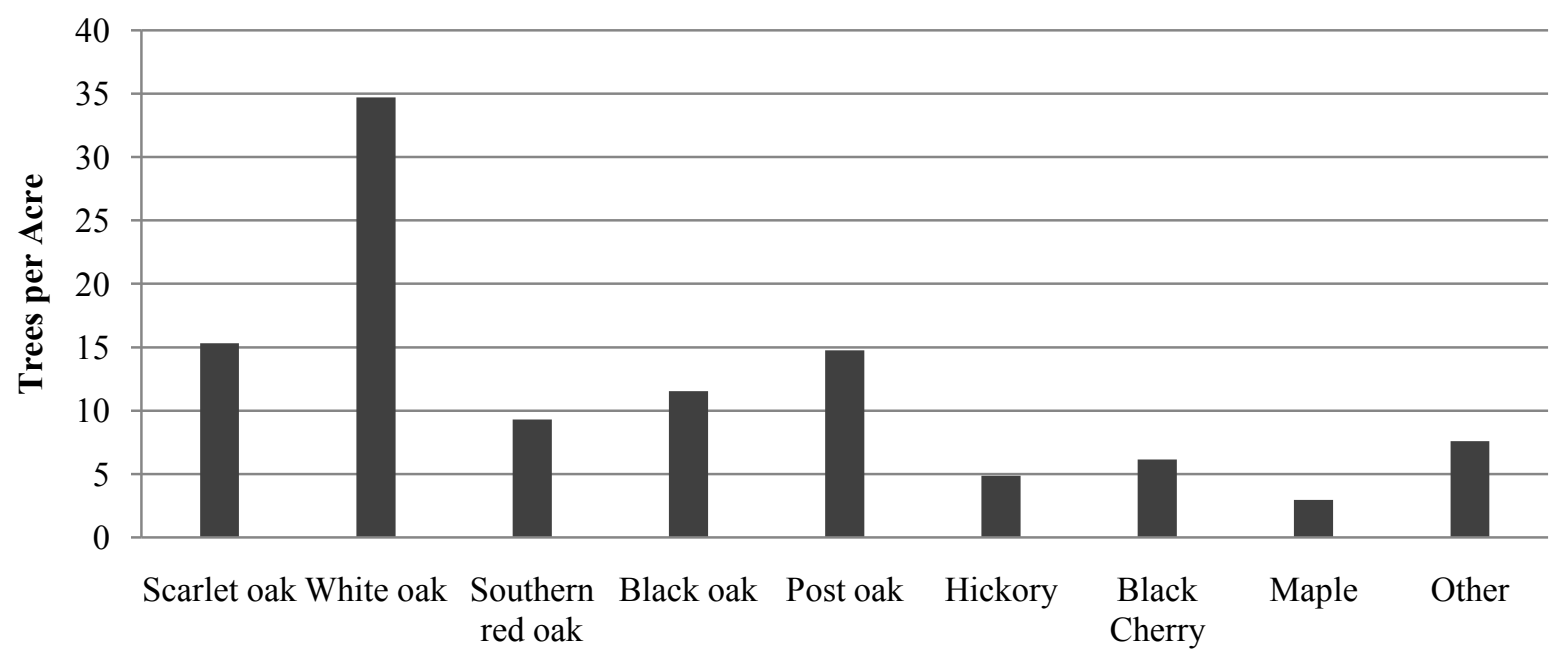

Figure 2. Pre-treatment trees per acre for the eight most abundant species and pooled trees per acre for the ten least abundant species. 


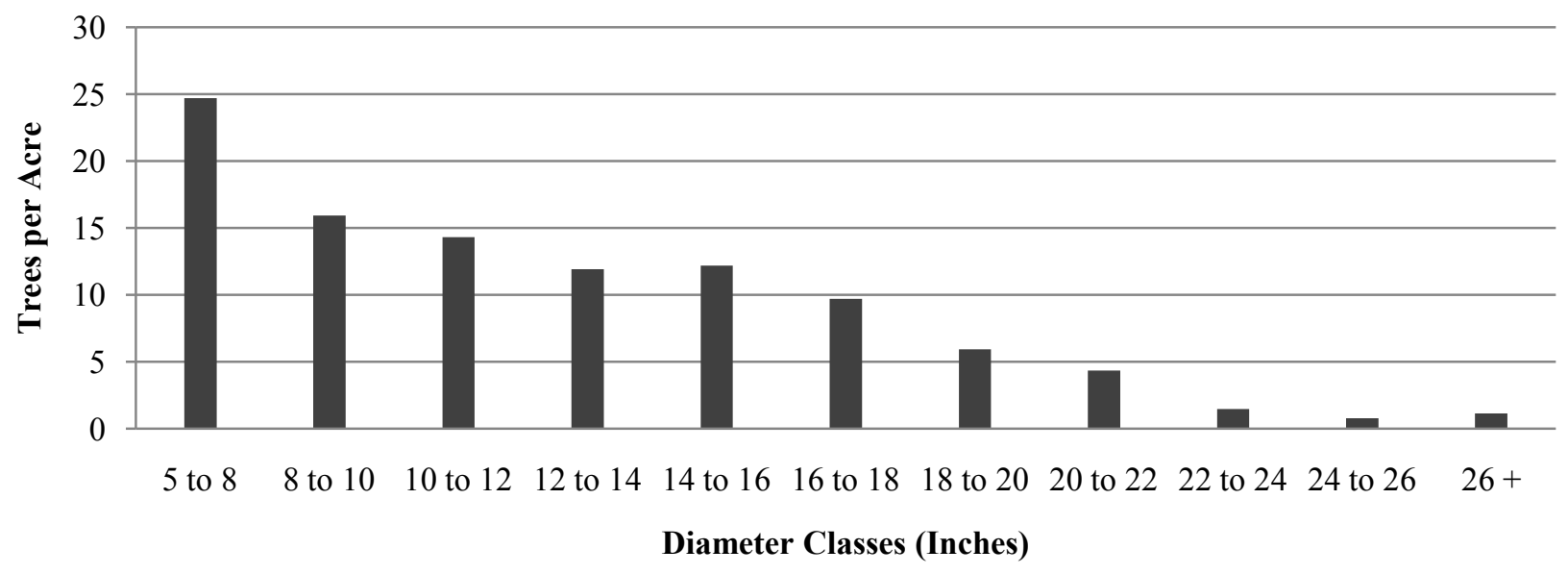

Figure 3. Pre-treatment diameter distribution of the trees per acre

\subsection{Silvicultural treatments}

Two different sivilcultural treatments were applied to the forest stands: single tree selection and shelterwood strips. Both treatments aimed to reduce basal area to improve growth of residual trees, harvest mature red and black oak near the end of their lifespan, and encourage the establishment of a new cohort of over story species in the regeneration layer. White oaks, post oaks, hickories and soft mast producing species like persimmon, elm, dogwood, and hawthorn were all favored as leave trees throughout the thinned areas. Red oaks and black oaks, with a few exceptions when meeting density targets, were favored for removal due to the nearness to their maximum expected lifespan. The optimal tree selection scenario for both treatments was the removal of a dominant red oak that released an intermediate crown class white oak of the same age cohort. Snag trees and hollow cull trees were favored as leave trees for the wildlife benefits that they create (Franklin et. al 1981, Harmon et. al 1986, McMinn et. al 1993) and to maintain 
compliance with Woody Biomass Best Management Practices (WBMPs) required by the harvest sale contract (MDC 2008).

\subsubsection{Single tree selection}

The single tree selection method reduced the over story density to three different target residual basal area densities: 30,40 , and 50 square feet per acre. The total area of each single tree selection plot was 3 acres. The over story residual tree placement aimed to leave trees homogenously distributed across the site. However, several small gap openings were created in the harvest process that are deemed to be large enough to initiate a new cohort of trees with enough light to recruit (grow) up into the over story. A follow up harvest will be conducted in 15-20 years to remove the residual trees left in this initial treatment and to thin the new cohort and select dominant stump sprouts.

\subsubsection{Shelterwood Strips}

The shelterwood strip treatment was completed at two varying strip widths of 75 and 150 feet and approximately 450 feet in length. The area within the strips was thinned down to a target residual basal area density of 40 square feet per acre. The total area of each 75 foot wide and 150 foot wide treatment was 0.75 and 1.5 acres respectively. The goal of this treatment was to improve the regeneration conditions in the thinned strips so that after 15 to 20 years a second pass harvest can remove the residual trees in the strips to release the young trees and thin stump sprouts to a single stem. During this follow-up harvest the 75 foot wide buffers strips left during this first stage harvest will be thinned for the first time. A final harvest would then occur another 15 to 20 years after the follow-up harvest to remove the residual trees original buffer strips, releasing the new cohort below them and to thin the original shelterwood strips. Ultimately, this harvest 
treatment aims to transition the mature even-age forest into an uneven age forest with at least two age classes growing where both mature and pre-commercial trees can be removed every 15 to 20 years.

\subsection{Experimental Design}

Two replications were completed in the study harvest. Each replication had three single tree selection treatments of approximately 3 acres each, four 75 foot wide shelterwood strips of approximately 0.75 acres each, two 150 wide shelterwood strips of approximately 1.5 acres each and one control plot of approximately 3 acres (Table 2).

All harvest plots had a 75 foot buffer of unthinned area between the plots.

Table 2. Silvicultural treatment lists with basal area retention targets and acres harvested.

\begin{tabular}{|l|c|c|c|}
\hline \multicolumn{1}{|c|}{ Treatment } & $\begin{array}{c}\text { Basal } \\
\text { area } \\
\text { retention }\end{array}$ & $\begin{array}{c}\text { Number } \\
\text { of plots }\end{array}$ & Area (acres) \\
\hline Single tree selection & 30 sq. ft. & 2 & 5.87 \\
\hline Single tree selection & 40 sq. ft. & 2 & 5.91 \\
\hline Single tree selection & 50 sq. ft. & 2 & 5.74 \\
\hline Control & $\mathrm{Na}$ & 2 & 5.95 \\
\hline Shelterwood (75 feet width) & 40 sq. ft. & 8 & 6.9 \\
\hline Shelterwood (150 feet width) & 40 sq. ft. & 4 & 6.24 \\
\hline Total study harvest & & 20 & 36.61 \\
\hline
\end{tabular}

All the plots were located on the north side of state highway KK on a north facing aspect with minimal slope (Figure 4). The forest stand conditions were homogenous throughout all of the harvest plots and no observable stocking or volume differences between the treatments were observed. Two landings were utilized during the harvest; each was located directly adjacent to the state highway. 


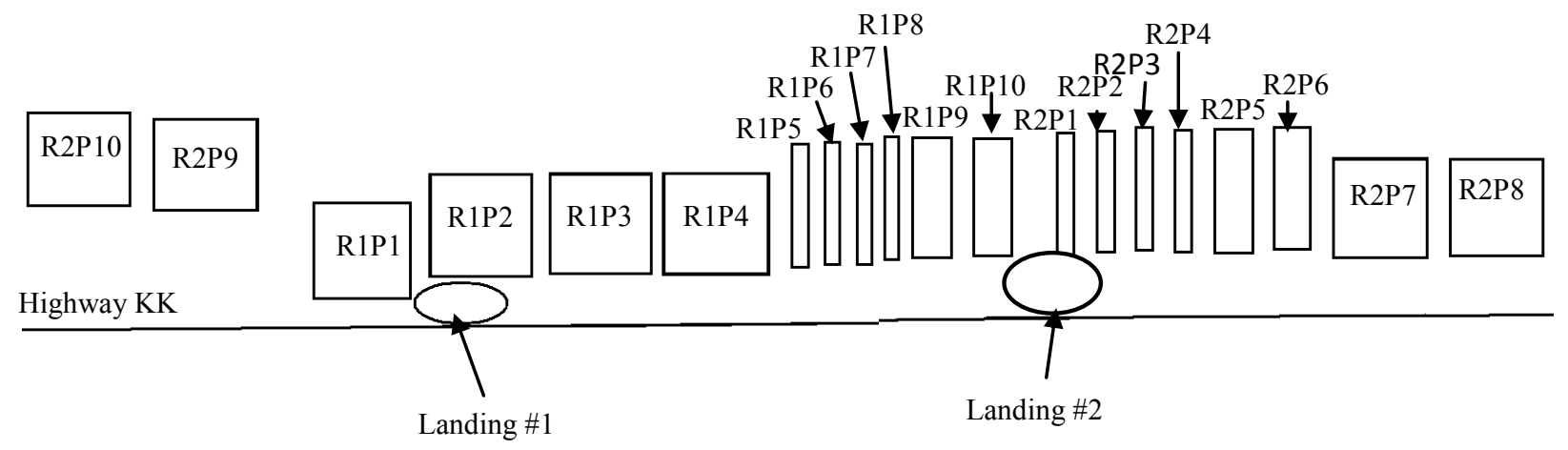

Figure 4. Schematic map of sample plot layout $(\mathrm{R}=$ replication number and $\mathrm{P}=\mathrm{plot}$ number). Square plots are 3 acres, either single tree selection or control. Narrow plots are shelterwood strips, either 75 feet or 150 feet in width and approximately 450 feet long.

Skid trails were marked throughout the single tree selection square treatment plots in a fish bone pattern to help the equipment operators cut and remove the trees with minimal damage to the soil and residual trees. Bumper trees were market at major turns before treatment to help the operators pivot and turn large logs as they return to the landing site where the logs are processed. The shelterwood strips were positioned perpendicular to the main skid trail, thus, requiring only one major 90 degree turn between the harvested area and the landing site. The rationale behind this design was to simplify the skid trail layout to reduce operational time and therefore risk of soil compaction and residual damage, and to reduce cost of harvesting. Furthermore, the unthinned buffer strips between the harvested plots provide a visual barrier to the forest operation.

\subsection{Harvest Equipment}

This study utilized an equipment suite able to complete an integrated harvest in mature hardwoods. The equipment is larger than what is more typical to the Ozarks 
region. Equipment utilized in the operation include a feller buncher with hot saw, grapple skidder, knuckleboom loader with bucking saws and delimber, and a stationary chipper that is fed material by the loader. The operational flow from standing trees to processed material leaving the site follows this general pattern: (1) feller buncher (or for larger trees a chainsaw) cuts trees and lays them into piles along skid path,(2) a crew member cuts main branches off trees with chainsaw, (3) skidder picks up bundles and drags them to the landing site, (4) loader picks up bundles one tree at a time to delimb, buck into product length, and stack into different piles, (5) log truck pulls into landing and SHWP logs are stacked into the back of the log truck, (6) chip van pulls into landing in front of chipper and the loader feeds small diameter trees, branches, and other material too small to be sold as SHWP into the chipper. There were exceptions to this harvest operational flow, but they were generally minimal. Exceptions primarily involved the skidder doing work other than dragging bundles to the landing. These actions include assisting in felling very large trees by hand, clearing skid paths or landings, building water bars, and pushing piles small diameter material closer to the loader when the chipper was in operation. Complete information about equipment specifications used in the study will be presented in the Results section.

\subsection{Best Management Practices}

The sale of the harvest rights from the Missouri Department of Conservation (MDC) to a private logging group included compliance with recommended WBMPs. These practices are currently voluntary in privately-owned forestlands the state of Missouri, but are mandatory on all sales that take place on public lands. Regular 
discussions were held between the loggers, landowners and researchers to ensure that compliance with the WBMPs was maintained.

\subsection{Data Collection}

\subsubsection{Time-in-Motion Data Collection}

To determine individual machine and overall system productivity of the harvest, each function of the operation was studied as harvesting occurred (time-in-motion study). Functions included: Felling, Skidding, Processing and Sorting, Loading, Chipping, and Hauling. Data collection methods were developed after similar studies and personal communication with individuals with experience in this field of study (Miyata 1980, Epplin 1996, O’Neal 2007, Bolding et al. 2009, Spinelli, 2009, Brandon O'Neal ${ }^{1}$ and Tom Gallagher ${ }^{2}$ ). An "integrated harvest" approach was used to gather SHWP and fuel chips, meaning that both products were brought to the landing at the same time in a single pass style operation (Bolding et al. 2009). On each machine except the log trucks, a "Yellow Activity Monitoring System" data recorder was attached to determine the amount of time that the machine was in operation (Figure 5). This is known as the machine's total productive mechanized hours (PMH). Yellow Activity Monitoring System, here after referred to as "Yellow Boxes", are manufactured by Kinetic Electronic Designs (www.ked.co.za). Yellow Box data collectors are able to detect vibrations of machines and yields PMH with resolution down to the minute (see sample data sheet in Appendix C). PMH for each piece of harvest equipment was determined this way.

\footnotetext{
${ }^{1}$ Personal communication May, 2009

${ }^{2}$ Personal communication May, 2009
} 


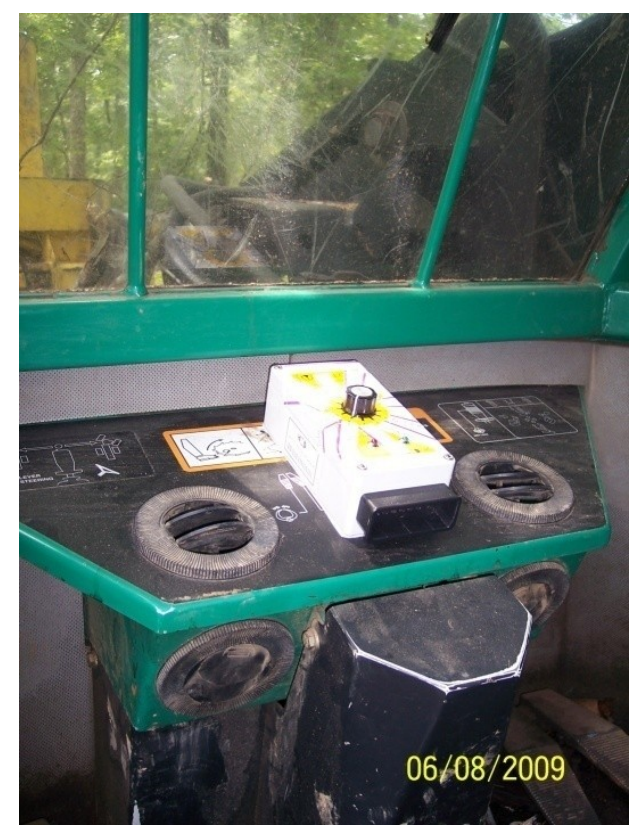

Figure 5. Yellow Activity Monitoring System data collector "Yellow Box" attached to skidder

\subsubsection{Field Observations of Equipment}

Field researchers collected data to supplement the yellow box time-in-motion data that was used to estimation of the amount of time that that each piece of equipment spent working directly with fuel chips and SWHP materials. This estimate was made for all pieces of equipment and is called "\%CHIPS". This estimate is important in distributing the observed PMHs of each piece of equipment between the two products harvested in the study. Furthermore, supplemental data provided additional insight into the productivity and bottlenecks of the harvesting system.

The most in-depth field data collected was on the skidder. Two field researchers tracked the skidder at the landing and in the woods. Times that the skidder left the landing, arrived at the next bundle in the woods, left the woods for the landing, and dropping the bundle at the landing were recorded. These time figures were compiled to 
estimate skidder "cycle time", the time to leave the landing and return with a bundle of logs. The location of each bundle pickup was recorded to estimate skid distance. A linear regression model was created to understand the relationship between skid distance, delays, and the resulting cycle time. This model is not incorporated into the economic feasibility analysis. Results from this regression analysis and sample data collection sheets are presented in Appendix D. Data from the regression model holds potential for future harvest modeling efforts.

The composition of each bundle brought to the landing by the skidder was recorded to estimate the amount of SHWP and fuel chips material brought to the landing for processing. The percentage of stems brought to the landing considered to be fuel chips was used as an estimate of the percentage of time (\%CHIPS) that both the skidder and feller buncher spent working directly with fuel chips. This figure makes two key assumptions. First, that it takes the feller buncher equal amount to time to cut a small diameter (fuel chips) tree as it does a large diameter (SHWP) tree. Secondly, that it takes the skidder equal amount of time to drag in a small diameter piece of wood as it does to drag in a large piece of wood. Both of these assumptions are reasonable when the travel time to and from the harvested area are factored into the time per piece. This assumption probably results in an over estimate of the \%CHIPS for the feller buncher and a under estimate of the \%CHIPS for the skidder. However, no other empirical data is available to generate an estimate so the same percentage will be used for both pieces of equipment. Relevant literature about integrated harvests provides little insight into the specifics of how harvest costs are distributed between fuel chips and SWHP production for equipment that handles both products. 
The second most intensive supplemental data collection was on the loader.

Activity sampling was conducted on the loader throughout the harvest to measure the proportion of productive time that the loader spent performing specific activities (Olsen and Kellogg 1983). While activity sampling was being conducted a field researcher would record exactly what the loader was doing every 30 seconds. These observations were then categorized into five categories; feeding the chipper, loading the log truck, sorting SHWP, sorting fuel chips, and delay. The \%CHIPS figure used for the loader was the sum of the time percent time feeding the chipper and sorting fuel chips.

Finally, data was collected on the log trailer that tracked the amount of time it took to complete a hauling cycle. Activities included time loading the truck, securing load, driving to mill, weighing, unloading, and returning to the site. Since there was no data available on the unloading it was assumed that it required the same amount of time to unload as it does to load. Furthermore, it was assumed that weighing the log truck added 10 minutes. Google Maps were used to estimate the distance traveled on each road type and the default average speeds for different road types used in the "General Groundbased Harvesting System Analysis" model were used to estimate hauling time (USDA year not available). The hauling times were estimated by calculating the number of miles spent on different road types and the average speed expected on each road type (Table 3 ).

Table 3. Assumed hauling speeds for different road types

\begin{tabular}{|l|c|}
\hline & Average Speed (mph)* \\
\hline Woods road & 10 \\
\hline Asphalt 2-way & 45 \\
\hline Highway & 50 \\
\hline Interstate & 65 \\
\hline
\end{tabular}

*Assumed speeds were gathered from the "General Ground-based Harvesting System Analysis" model (USDA, year not available) 


\subsubsection{Estimating Yields and Revenues}

As logs were felled a plot number was painted on the bottom of each tree. These numbers were re-sprayed on the logs if the bottom end was bucked off at the landing. Each truck load of logs that left the site was tallied to determine the total number of logs leaving the site and from which plots they were harvested. Load weights and volumes measurements reported by the mill were used to estimate how much material was removed from each treatment plot. The mills also reported purchase prices per unit for each of the loads.

It was much more difficult to determine which plot the fuel chips quality material was harvested from. Field researchers and the logging crew estimated where the material came from to fill each chip fan. Plot numbers and percentages from each were estimated for each chip van. Percentages were later adjusted during data analysis to more evenly distribute the fuel chips material between harvest plots.

\subsubsection{Residual Damage Assessment}

After the timber harvest, a complete inventory of the residual trees was taken for all the study plots. Plot, diameter, species, presence of damage, source of damage, length and width of damage, and whether the tree was originally marked to remain or not was recorded by field researchers after the harvest was complete. Furthermore damage was collected on trees located along the main skid path used to bring logs to the landing.

\subsection{Data Analysis}

\subsubsection{Analysis Software}

All data was entered into Microsoft Excel spreadsheets for analysis and estimation of production rates, cost figures, and to estimate breakeven prices through a 
sensitivity analysis. Yellow Box data was analyzed using the Yellow Activity Monitoring System, Version 2.7.10.0 software provided with the Yellow Box hardware. Time in motion data collected by the Yellow Boxes was entered into Microsoft Excel and integrated with data collected in the field to supplement times collected by the field researchers and for use in production rate estimation. Equipment cost figures were estimated using the "General Ground-based Harvesting System Analysis" model produced by the Forest Service's Forest Operations Research Unit to estimate two important cost figures: fixed equipment cost (cost per scheduled mechanized hour and variable equipment costs (cost per productive mechanized hour) (USDA year not available). These two cost per hour figures were multiplied by the actual productive mechanized hours observed via Yellow Boxes and field observations, as well as the observed scheduled mechanized hours (SMH) needed to complete the harvest. Finally, SAS 9.2 statistical software was used to complete regression analysis for the skidder cycle time model presented in Appendix D and to conduct ANOVA mean comparisons to detect statistical differences between silvicultural treatments. Key t-tests conducted include testing to detect difference in the tons removed, cost per ton removed, and residual damage.

\subsubsection{Fixed Equipment Cost Estimation}

Fixed equipment costs are those associated with owning the equipment (Miyata 1980). These costs must be paid regardless of the amount of time the equipment is in operation and is independent from actual usage (Miyata 1980). Factors that influence the 
fixed costs are purchase price, equipment lifespan, insurance, taxes/fees/tags, depreciation rate, interest rate of loans, and salvage price. The sum of these costs in a given year was distributed across the number of scheduled hours in a year to yield a cost per SMH. Annual scheduled hours are generally assumed to be 2,000 hours, or 40 hours a week for 50 weeks a year. This number was used for all pieces of equipment except the $\log$ truck and trailer, which assumed 2,500 scheduled hours a year, or 50 hours a week for 50 weeks a year. Inputs cost figures for the equipment was provided by the contracted logging operator (Table 4). These cost factors were used in the General Ground-based Harvesting System Analysis model to estimate the cost per SMH (Equation 1).

Equation 1:

\section{$\frac{\$}{S M H}$}

$[($ Purchase Price $\times(1-$ Salvage $\%)) \times$ Capital Recovery Factor + $=\frac{(\text { Salvage } \% \times \text { Purchase Price } \times \text { Interest Rate })+\text { Insurance }+ \text { Taxes }]}{\frac{S M H}{y r}}$

Where; Salvage $\%$ = the Salvage Price $/$ Purchase Prices and

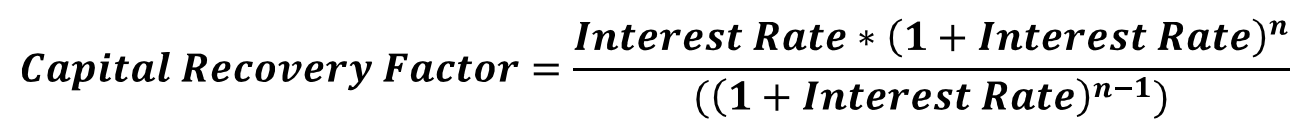

Where; Interest rate $=10$ percent, and " $n$ " = the equipment life span in years.

Table 4. Equipment utilized in study harvest and the factors influencing the cost of ownership, the cost per scheduled mechanized hour.

\begin{tabular}{|r|c|c|c|c|c|}
\hline & $\begin{array}{c}\text { Feller- } \\
\text { Buncher } \\
\text { Timberjack } \\
740\end{array}$ & $\begin{array}{c}\text { Skidder } \\
\text { Timberjack } \\
760 \mathrm{~B}\end{array}$ & $\begin{array}{c}\text { Chipper } \\
\text { Vermeer }\end{array}$ & $\begin{array}{c}\text { Loader } \\
\text { Timberjack } \\
530\end{array}$ & $\begin{array}{c}\text { Logging } \\
\text { Truck }+ \\
\text { Trailer }\end{array}$ \\
\hline Purchase Price (w/o tires)* & $\$ 65,000$ & $\$ 55,000$ & $\$ 60,000$ & $\$ 50,000$ & $\$ 45,000$ \\
\hline SMH per year* & 2,000 & 2,000 & 2,000 & 2,000 & 2,500 \\
\hline
\end{tabular}




\begin{tabular}{|r|c|c|c|c|c|}
\hline Life (yrs)* & 5 & 5 & 5 & 5 & 5 \\
\hline Salvage (\% of new)* & 0.38 & 0.45 & 0.41 & 0.40 & 0.51 \\
\hline Insurance (\$yr)* & $\$ 3,250$ & $\$ 2,750$ & $\$ 2,500$ & $\$ 2,500$ & $\$ 2,250$ \\
\hline Taxes/tags* & 0.00 & 0.00 & 0.00 & 0.00 & $\$ 1,100$ \\
\hline Depreciation (\$yr)** & $\$ 8,060$ & $\$ 6,050$ & $\$ 7,080$ & $\$ 6,000$ & $\$ 4,410$ \\
\hline Capital Recovery Factor** & 0.2638 & 0.2638 & 0.2638 & 0.2638 & 0.2638 \\
\hline Owning Costs per SMH** & $\$ 8.18$ & $\$ 6.60$ & $\$ 7.15$ & $\$ 6.21$ & $\$ 4.58$ \\
\hline
\end{tabular}

*Data provided by the logging operator

**Calculated with the General Ground-based Harvesting System Analysis model

\subsubsection{Variable Equipment Costs Estimation}

Variable equipment costs are those associated with operating the equipment (Miyata 1980). These costs are directly tied to the number of hours that a piece of equipment is running. Factors affecting the variable costs of operation include fuel use and price, oil use and price, maintenance and repair, tire lifespan and price, and other miscellaneous operating costs. Estimate for these figures were provided by the operator. Variable equipment costs are referred to as cost per PMH and are a function of many different variables (Table 5). These cost figures are used by the General Ground-based Harvesting System Analysis model to estimate the \$ per PMH for harvest equipment (Equation 2) and for hauling (Equation 3). Note that fuel prices observed during this harvest were \$2.15 per gallon for off-road diesel fuel, \$2.60 per gallon for on-road diesel fuel (log truck only), and $\$ 8.00$ per gallon for oil (hydraulic and motor) (MDNR Energy Center, 2009).

Equation 2:

$$
\begin{array}{r}
\frac{\$}{\text { PMH }}=\text { FuelUse } * \text { HorsePower } * \text { FuelPrice }+ \text { OilUse } * \text { OilPrice }+ \text { R\&M } \\
* \frac{\text { Depreciation }}{\text { SMH } / y r}+\frac{\text { Monthly Misc. Operating Cost }}{\left(\frac{\text { Hours }}{\text { Month }}\right) * \text { Utilization }}
\end{array}
$$

Equation 3: 


$$
\begin{gathered}
\frac{\$}{\text { PMH }}=\frac{\text { AveSpeed }}{\text { mpg }} * \text { Fuel Price }+ \text { Oil Use } * \text { Oil Price }+R \& M \\
* \frac{\text { Depreciation }}{\frac{\text { SMH }}{y r}}+\frac{\text { TireCost }}{\text { Tirelife }} \\
+\frac{\text { Monthly Misc. OperatingCost }}{\left(\frac{\text { Hours }}{\text { Month }}\right)}
\end{gathered}
$$

Table 5. Equipment utilized in study harvest and the factors influencing cost of operation, cost per productive mechanized hour

\begin{tabular}{|r|c|c|c|c|c|}
\hline & $\begin{array}{c}\text { Feller- } \\
\text { Buncher } \\
\text { Timberjack } \\
740\end{array}$ & $\begin{array}{c}\text { Skidder } \\
\text { Timberjack } \\
760 \mathrm{~B}\end{array}$ & $\begin{array}{c}\text { Chipper } \\
\text { Vermeer }\end{array}$ & $\begin{array}{c}\text { Loader } \\
\text { Timberjack } \\
530\end{array}$ & $\begin{array}{c}\text { Logging } \\
\text { Truck + } \\
\text { Trailer }\end{array}$ \\
\hline Horsepower* & 178 & 178 & 260 & 230 & 425 \\
\hline Fuel Cons (g/hp-hr)** & 0.042 & 0.025 & 0.047 & 0.025 & 4.4 \\
\hline Daily Fuel Use (gal)* & 25 & 25 & 15 & 21 & 90 \\
\hline Oil use (gal/hr) & 0.05 & 0.05 & 0.05 & 0.15 & 0.04 \\
\hline Monthly Oil Use (gal)* & 4 & 6 & 2 & 12 & 10 \\
\hline $\begin{array}{r}\text { R\&M (\% of } \\
\text { Depreciation.)** }\end{array}$ & 1.25 & 0.83 & 0.85 & 0.80 & 1.50 \\
\hline $\begin{aligned} \text { Annual Repair \& } \\
\text { Maintenance (\$)* }\end{aligned}$ & 10,075 & 5,022 & 6,018 & 4,800 & 6,615 \\
\hline Tire Cost (\$)* & 7,200 & 8,000 & 2,000 & 2,000 & 6,000 \\
\hline Tire Life (hrs)* & 2,000 & 7,600 & 8,400 & 8,400 & 2,000 \\
\hline $\begin{array}{r}\text { Misc. Operating } \\
\text { (\$/month)* }\end{array}$ & 1,000 & 1,000 & 1,000 & 500 & 1,500 \\
\hline Base Utilization* & 0.41 & 0.71 & 0.18 & 0.45 & 0.8 \\
\hline $\begin{array}{r}\text { Variable costs } \\
\text { (\$/PMH)** }\end{array}$ & $\$ 39.29$ & $\$ 21.72$ & $\$ 58.87$ & $\$ 22.66$ & $\$ 34.48$ \\
\hline
\end{tabular}

*Data provided by the logging operator

**Calculated by the General Ground-based Harvesting System Analysis model

\subsubsection{Breakeven Prices}

One of the stated objectives of this study was to determine the per unit product prices needed for the total revenues to equal total costs. Thus, the "break-even" price per ton would be equal to the harvest cost per ton. The cost per ton is basically the total costs of harvesting divided by the number of tons harvested. To yield a total cost per ton for a 
given product type the fixed equipment cost per ton, variable equipment cost per ton, stumpage cost per ton, labor cost per ton, and hauling cost per ton were summed for that product. Since there were two products harvested in this study harvest the $\%$ CHIPS estimate was needed to distribute the observed equipment costs between the two products. Equations 4 and 5 show the process used to determine fixed equipment costs per ton of SHWP for a single piece of equipment.

Equation 4:

$$
\frac{\text { Tons SWHP }}{S M H}=\left[\frac{(\text { Tons SHWP })}{S M H *(1-\% C H I P)}\right]
$$

Equation 5:

$$
\frac{\text { Fixed Cost }}{\text { Ton SHWP }}=\frac{\left[\frac{\text { Cost }}{\text { SMH }}\right]}{\left[\frac{\text { Tons SHWP }}{\text { SMH }}\right]}
$$

Similarly, Equations 6 and 7 were used to estimate the fixed equipment cost per ton of fuel chips. These four equations were applied to each piece of equipment and the fixed cost per ton for both products is summed to obtain total fixed equipment cost per ton SHWP and total fixed equipment cost per ton fuel chips for the entire equipment suite.

Equation 6:

$$
\frac{\text { Tons Chipwood }}{\text { SMH }}=\left[\frac{\text { Tons Chipwood }}{\text { SMH } * \% \text { CHIP }}\right]
$$

Equation 7:

$$
\frac{\text { Fixed Cost }}{\text { Ton Chipwood }}=\frac{\left[\frac{\text { Cost }}{\text { SMH }}\right]}{\left[\frac{\text { Tons Fuel chips }}{\text { SMH }}\right]}
$$


The next key component was the variable equipment cost per ton. Equations 9 through 11 show how variable equipment costs were calculated for both SHWP and fuel chips. These equations were applied to each piece of equipment and the variable cost per ton for both products was summed to get total variable equipment cost per ton SHWP and total variable equipment cost per ton fuel chips for the entire equipment suite.

Equation 8:

$$
\frac{\text { Tons SWHP }}{P M H}=\left[\frac{(\text { Tons SHWP })}{P M H *(1-\% C H I P)}\right]
$$

Equation 9:

$$
\frac{\text { Variable Cost }}{\text { Ton SHWP }}=\frac{\left[\frac{\text { Cost }}{\text { PMH }}\right]}{\left[\frac{\text { Tons SHWP }}{P M H}\right]}
$$

Equation 10:

$$
\frac{\text { Tons Chipwood }}{\text { PMH }}=\left[\frac{\text { Tons Chipwood }}{\text { PMH } * \% \text { CHIP }}\right]
$$

Equation 11:

$$
\frac{\text { Variable Cost }}{\text { Ton Chipwood }}=\frac{\left[\frac{\text { Cost }}{\text { PMH }}\right]}{\left[\frac{\text { Tons Chipwood }}{\text { PMH }}\right]}
$$

The labor costs were distributed evenly between both product types by dividing total labor cost by the total tons removed, pooling both products. This yields an even labor cost per ton for both product types.

The stumpage costs paid by the logging operator earned them the rights to harvest unmarked material within the study harvest plots. The contract signed between the MDC and the operator included both merchantable SHWP and smaller diameter trees above 5 inches at breast height but below merchantable diameter specifications. The stumpage 
bid price received for the material was below the average reported stumpage price for the region at that time. A lower stumpage price was the result unusual equipment requirements attached to the harvest contract and other requirements of the data collection process. Thus a higher and more realistic, yet still conservative, stumpage price rate was used in this analysis. There was limited literature found that suggested how to distribute the stumpage cost between the two product types for use in the economic analysis. Distributing the cost equally between the two products makes the breakeven price for the fuel chips artificially higher than would expected. Thus, this study assumed that the stumpage bid was intended to only pay the landowner for the SHWP and that all the fuel chips material will undergo a "cut and share" method between the operator and landowner where landowner received a set prices for each ton of fuel chips delivered to the buyer.

A Yellow Box was not attached to the log truck, therefore a different method for estimating PMH was utilized. Total PMH for the logging truck was estimated by using road type data (Google Map) and assumed highway speeds (Table 3) to estimate round trip hauling time. The estimated times to load the truck, secure the load, weigh, and unload were included in the total time of operation (PMH). PMH of hauling was multiplied by the cost per PMH and the observed SMH multiplied by the cost per SMH to estimate the total cost of hauling. This figure was divided by the total number of miles hauled to estimate a hauling cost per mile (Equation 12). This figure was then divided by the average tons per load to estimate the cost per ton-mile (Equation 13). The cost per ton-mile can be multiplied by the number of miles to the mill to estimate the hauling cost per ton. 
Equation 12:

$$
\frac{\text { Cost }}{\text { mile }}=\frac{P M H *\left(\frac{\$}{P M H}\right)+S M H *\left(\frac{\$}{S M H}\right)}{\text { Total Miles }}
$$

Equation 13:

$$
\frac{\text { Cost }}{\text { ton } / \text { mile }}=\frac{\frac{\text { Cost }}{\text { mile }}}{\text { average load size }}
$$

\subsection{System comparisons}

This study analyzed several scenarios with different assumptions about the equipment utilized, input fuel cost, equipment purchase prices, and others. These scenarios will be presented in sections 3.5 and 3.6. The different assumptions made for each scenario are introduced at the beginning of each section or subsection. 


\section{Results and Discussion}

This section explores difference between treatments (3.1), volumes harvested (3.2), prices and revenues observed (3.3). Section 3.4 presents results from the field observations. Section 3.5 shows and discuss all of the costs made during this study harvest. Section 3.6 compiles individual cost components into a complete harvest system profit/loss analysis. Section 3.7 introduces five different sensitivity analysis scenarios. Finally, section 3.8 outlines the residual damage of the study harvest.

\subsection{Differences between treatments}

One of the key questions of this study was to test the efficacy of two treatment designs: single tree selection (at three residual basal area targets), and shelterwood strips (at two different widths). The observed difference between treatments in the tonnage of sawlogs and fuel chips per acre removed is presented in Table 6 . Table 6 reports the results of $F$-statistics comparing mean differences and their corresponding $p$-values. Small $p$-values suggest differences between treatment means were the single tree selection treatment yielded a greater amount of tonnage than the shelterwood strips. Since there were no observable differences in the pre-treatment stocking and volume levels the differences in volume harvested are assumed to be attributed to harvest intensity. 
Table 6. Treatment mean comparisons of tons per acre removed. $P$-values less than 0.05 indicated significant differences.

\begin{tabular}{|c|c|c|c|}
\hline Treatment Comparison & $\begin{array}{c}\text { Degrees } \\
\text { of } \\
\text { Freedom }\end{array}$ & $\begin{array}{c}\text { F- } \\
\text { value }\end{array}$ & p-value \\
\hline STS vs SW75 & 13 & 3.96 & 0.069 \\
\hline STS vs SW150 & 9 & 7.30 & 0.027 \\
\hline SW75 vs SW150 & 11 & 0.81 & 0.388 \\
\hline STS vs SW & 17 & 6.04 & 0.025 \\
\hline
\end{tabular}

STS: Single tree selection

SW75: 75 foot wide shelterwood strip

SW150: 150 foot wide shelterwood strip

There were no statistically significant differences in the mean costs of harvesting the different treatments. The feller buncher and skidder harvest costs per acre as well as the harvest costs per ton for all treatments were not significantly different as suggested by $p$-values greater than 0.05 (Table 7). Since there was no detectable difference in productivity for the feller buncher and the skidder between treatments, no difference in the mean cost per acre or cost per ton for the treatments was assumed. Thus, a financial justification calling one treatment superior to the other is not applicable in this study harvest. The primary reason that no significant difference in cost was detected was that there were other variables that had greater influence on the cost of harvesting such as distance of plot from landing, equipment operator, and equipment delay. All other cost components (stumpage, labor, chipper, loader, and hauling) are distributed equally across plots because there is not data available by which allocate the costs otherwise. Treatment comparisons for residual damage and ecological characteristics will be reviewed in Section 3.8. 
Table 7. Mean productivity of PMH per acre and Tons harvested per PMH for both the shelterwood strip (SW) treatment and the single tree selection treatment (STS). P-values indicate that there is no difference in the observed means.

\begin{tabular}{|c|c|c|c|c|}
\cline { 2 - 5 } \multicolumn{1}{c|}{} & Feller Buncher & Skidder & Feller Buncher & Skidder \\
\cline { 2 - 5 } \multicolumn{1}{c|}{$\begin{array}{c}\text { Average } \\
\text { Oberved PMH }\end{array}$} & $\begin{array}{c}\text { Average } \\
\text { Observed PMH } \\
\text { per Acre }\end{array}$ & $\begin{array}{c}\text { Average } \\
\text { Observed Tons } \\
\text { per PMH }\end{array}$ & $\begin{array}{c}\text { Average } \\
\text { Observed Tons } \\
\text { per PMH }\end{array}$ \\
\hline SW & 1.560 & 2.895 & 32.038 & 17.449 \\
\hline STS & 1.616 & 3.113 & 36.221 & 17.957 \\
\hline $\begin{array}{c}p \text {-value testing } \\
\text { for mean } \\
\text { differences }\end{array}$ & 0.821 & 0.529 & 0.439 & 0.857 \\
\hline
\end{tabular}

\subsection{Volumes Harvested}

Harvest volumes removed from the study site were recorded at the mill using two metrics: board feet (BF) and tonnage (ton). Using a12.33 ${ }^{3}$ pounds per board foot as a conversion factor; 1,066.66 tons of SHWP and 462.78 tons of fuel chips were removed from the site or 1,529.44 total tons. The tonnage to thousand board feet (MBF) conversion factor was assumed to be 0.16221 and the MBF to tons conversion factor is assumed to be 6.1650 . Green tons (2000 pounds) were the primary metric of volume reporting for this study to enable direct comparisons between SHWP and fuel chips. It was observed that 69.7 percent of the volume removed was SHWP while 30.3 percent of the volume was fuel chips. Volume removal throughout the study site varied from 63.5 tons per acre down to 35.8 tons per acres (Table 8 ). There were 38 log truck loads and 18 chip van loads removed over the course of the harvest.

\footnotetext{
${ }^{3}$ This conversion factor was used by local saw mills during study harvest.
} 
Table 8. Total tons per acre, fuel chip tons per acre, and solid hardwood product tons per acre removed from each sample plot.

\begin{tabular}{|c|c|c|c|c|}
\hline Treatment* & Plot \#** & $\begin{array}{c}\text { Ton/acre } \\
\text { Removed }\end{array}$ & $\begin{array}{c}\text { Tons/acre } \\
\text { Chips }\end{array}$ & $\begin{array}{c}\text { Tons/acre } \\
\text { SHWP }\end{array}$ \\
\hline STS (low) & R1P1 & 63.5 & 11.7 & 51.7 \\
\hline STS (low) & R2P7 & 55.9 & 17.2 & 38.7 \\
\hline STS (mid) & R1P2 & 50.1 & 18.2 & 31.9 \\
\hline STS (mid) & R2P9 & 57.8 & 18.0 & 39.8 \\
\hline STS (high) & R1P3 & 52.8 & 14.2 & 38.6 \\
\hline STS (high) & R2P8 & 49.7 & 14.7 & 35.1 \\
\hline SW (150) & R1P9 & 39.0 & 13.2 & 25.8 \\
\hline SW (150) & R1P10 & 35.8 & 12.6 & 23.1 \\
\hline SW (150) & R2P5 & 53.3 & 21.3 & 32.0 \\
\hline SW (150) & R2P6 & 47.2 & 16.3 & 30.9 \\
\hline SW (75) & R1P5 & 45.7 & 16.8 & 28.9 \\
\hline SW (75) & R1P6 & 54.3 & 17.8 & 36.6 \\
\hline SW (75) & R1P7 & 40.5 & 12.8 & 27.7 \\
\hline SW (75) & R1P8 & 39.6 & 8.3 & 31.3 \\
\hline SW (75) & R2P1 & 50.1 & 13.6 & 36.5 \\
\hline SW (75) & R2P2 & 51.1 & 15.4 & 35.7 \\
\hline SW (75) & R2P3 & 60.3 & 13.9 & 46.4 \\
\hline SW (75) & R2P4 & 42.1 & 17.4 & 24.7 \\
\hline Average & - & $\mathbf{4 9 . 4}$ & $\mathbf{1 5 . 2}$ & $\mathbf{3 4 . 2}$ \\
\hline
\end{tabular}

*STS=Single Tree Selection at three different basal area retentions, $\mathrm{SW}=$ shelterwood strip at two different strip widths in feet.

$* * \mathrm{R} \# \mathrm{P} \#$ indicates the replication and plot number

There were observed differences in the tonnage removed between silvicultural treatments (Figure 6). Mean comparison F-test statistics indicated that there were significant differences between the single tree selection (STS) treatments and the shelterwood strips at 75 feet wide (SW 75) treatments. The STS treatment and the shelterwood strips at 150 feet wide (SW 150) treatment were observed to be significantly different as well as the STS treatment and the two shelterwood strip widths pooled (SW) (Table 6). However, due to the low sample size and thus small degrees of freedom, these mean comparisons have little statistical power. 


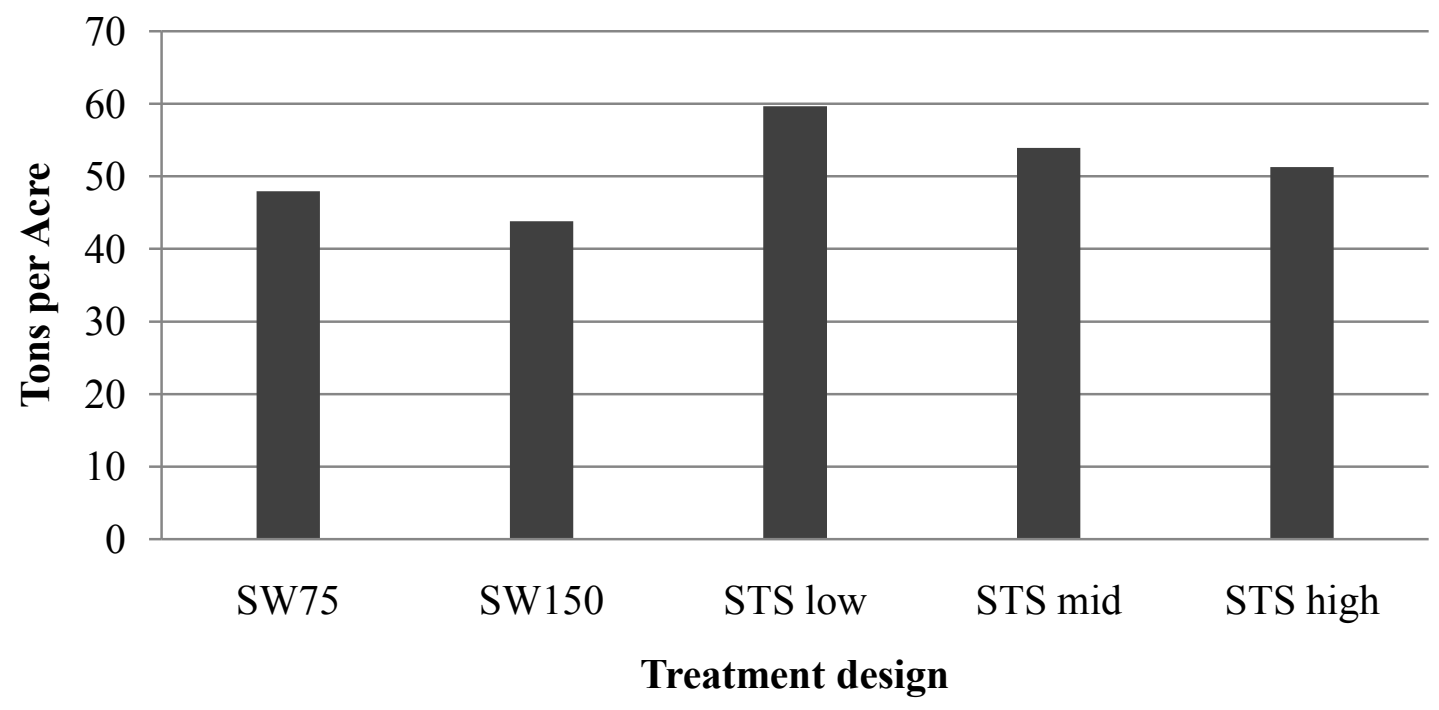

Figure 6. Average tons per acre removed by treatment

Pre and post-harvest inventory data showed that residual basal areas targets for each treatment were reached or the thinning reduced residual density below targets (Figure 7). Across the entire treated area white oak, post oak, hickory and species of lower abundance were favored to be left on site as residual trees (Figure 8).

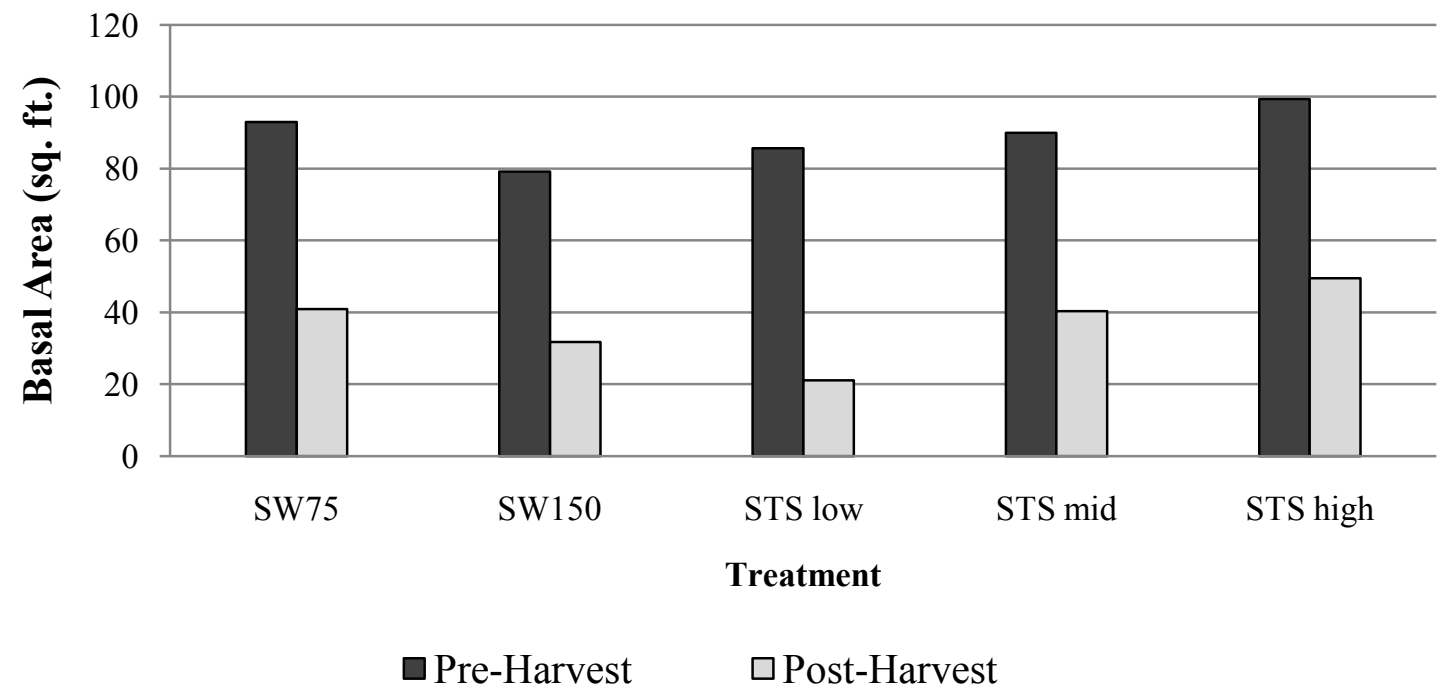

Figure 7. Pre and post basal area per acre for the five treatment designs 


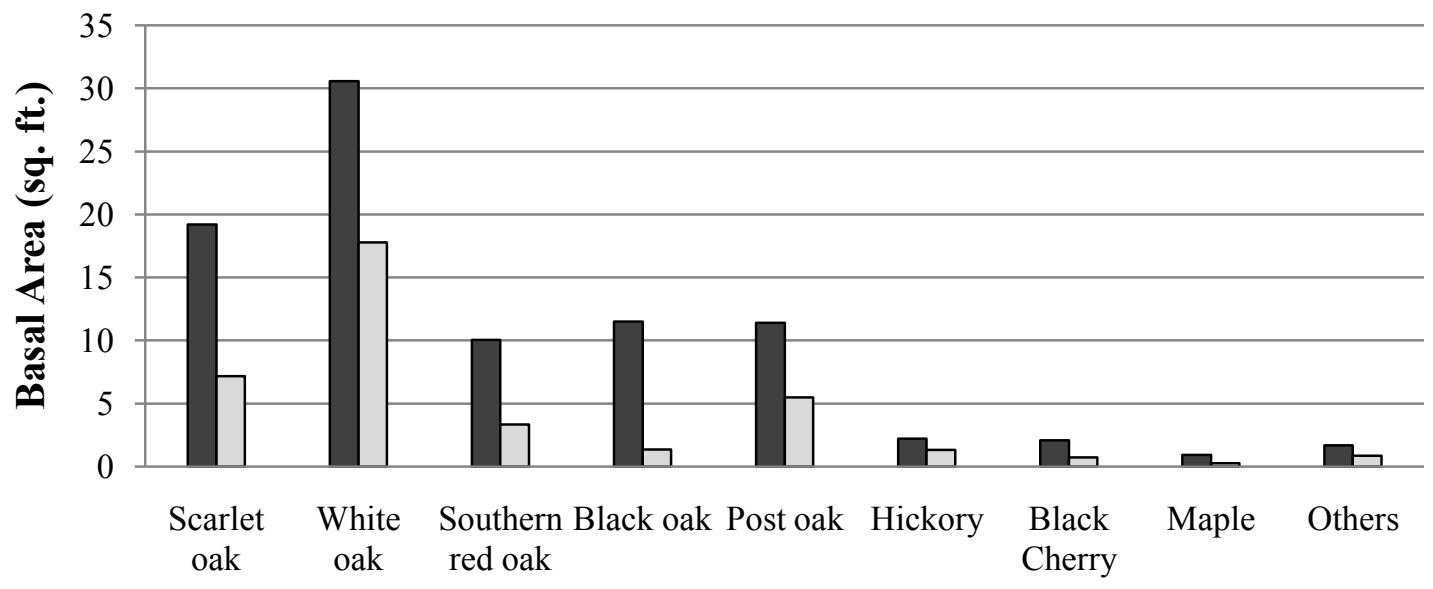

Pre-Harvest $\quad \square$ Post-Harvest

Figure 8. Pre and post treatment basal area for the eight most abundant over story species. The ten least abundant are pooled as "Others".

\subsection{Prices Observed for SHWP and Fuel Chips Products}

The prices received for solid hardwood products (SHWP) and fuel chips varied throughout the study harvest. SHWP logs were hauled to seven different sawmills, all receiving different prices between sawmills for various products. Product price variability in the SHWP material was more closely associated to product class than to hauling distance. In contrast, only two chip mills purchased fuel chips from this operation and hauling distance was a major contribution factor to the price of fuel chips (Table 9). The observed average SHWP product price was $\$ 32.64$ per ton and ranged from $\$ 21.10$ to $\$ 81.00$ per ton (Figure 9). The observed average fuel chips price was $\$ 22.08$ per ton and ranged from $\$ 0.00$ to 26.00 per ton. Total revenues from this study harvest (29.86 acres) was $\$ 45,033.34$ dollars. Of this total $\$ 10,216.18(23 \%)$ was derived from fuel chips and $\$ 34,817.16$ (77\%) was derived from SHWP. 
Fuel chips mill 1 was used during one week of the study harvest because fuel chips mill 2 unexpectedly closed its doors to fuel chips deliveries. A chip van from fuel chips mill 1 traveled almost 200 miles one-way to pick up three loads of fuel chips. The first load was given to the fuel chips buyer at no charge and the later two loads for only $\$ 5.00$ per ton. The hauling costs for sales made to fuel chips mill 1 were covered by the buyer and resulted in lower prices since due to the extremely long hauling distance. These low product prices drastically reduce the average price of fuel chips in the study. In a more realistic setting the logger would have waited for fuel chips mill 2 to reopen and sold the product for full price, thus for the harvest system and sensitivity analysis parts of this study the fuel chips product price will be assumed to be $\$ 26.00$ per ton for delivered material. The hauling costs for sales made to fuel chips mill 2 were $\$ 12.00$ per ton and were given to a third party contract hauler, thus the harvest operation only received $\$ 14.00$ per ton to cover harvesting, processing and stumpage costs.

Table 9. Solid hardwood product and fuel chips price results for the nine different product buyers observed in this study and the hauling distance to each of these buyers

\begin{tabular}{|c|c|c|c|c|c|}
\hline $\begin{array}{c}\text { Product and } \\
\text { buyers }\end{array}$ & $\begin{array}{c}\text { \# of } \\
\text { loads } \\
\text { delivered }\end{array}$ & $\begin{array}{c}\text { Average } \\
\text { price } \\
\text { (\$/ ton) }\end{array}$ & $\begin{array}{c}\text { Low price } \\
\text { (\$/ton) }\end{array}$ & $\begin{array}{c}\text { High price } \\
\text { (\$/ton) }\end{array}$ & $\begin{array}{c}\text { Distance to } \\
\text { mill (miles } \\
\text { one-way)* }\end{array}$ \\
\hline SHWP Sawmill 1 & 20 & 28.50 & 25.00 & 36.00 & 57 \\
\hline SHWP Sawmill 2 & 6 & 45.20 & 24.30 & 48.60 & 34 \\
\hline SHWP Sawmill 3 & 5 & 37.50 & 21.10 & 43.80 & 32 \\
\hline SHWP Sawmill 4 & 3 & $26.00^{* *}$ & $26.00^{* *}$ & $26.00^{* *}$ & 88 \\
\hline SHWP Sawmill 5 & 2 & 64.50 & 40.60 & 81.10 & 77 \\
\hline SHWP Sawmill 6 & 1 & 45.40 & 45.40 & 45.40 & 65 \\
\hline SHWP Sawmill 7 & 1 & 26.00 & 26.00 & 26.00 & 96 \\
\hline Fuel chips Mill 1 & 3 & 5.00 & na & na & 198 \\
\hline Fuel chips Mill 2 & 15 & $26.00^{* *}$ & na & na & 88 \\
\hline
\end{tabular}

*Miles estimated using Google Maps online software

** Contract haulers received $\$ 12.00$ per ton, thus the loggers only received $\$ 14.00$ to cover harvesting, processing, and stumpage expenses. $\mathrm{na}=$ Not applicable since fuel chips were not sold in $\mathrm{BF}$ and no price variation was observed in the fuel chips within the same buyer 


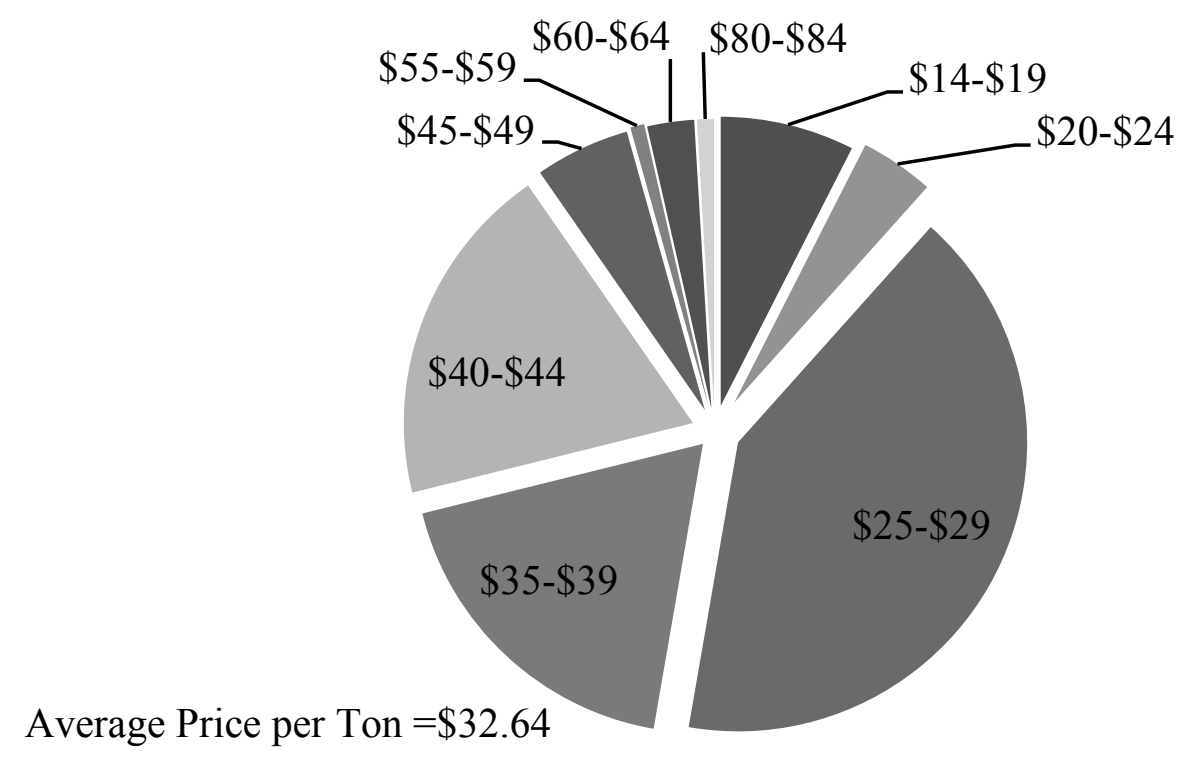

Figure 9. Distribution of observed solid hardwood product prices per ton

\subsection{Field Observed Productivity}

As outlined in section 2.6.2 the main objective of the field observation data was to determine how much time each piece of harvest equipment spent dealing directly with fuel chips and how much time was spent dealing directly with SWHP. These results are presented before the costs estimates because the \%CHIPS estimate is needed to distribute the costs of harvesting between the two products. The Chipper had a \%CHIPS value of 1.0 .

A total of 342 bundle deliveries were observed during the study with a total of 1,837 delivered stems. Thus, each bundle averaged 5.37 pieces. Field observations estimated that 754 of the 1,837 stems brought to the landing were small diameter material and thus categorized as fuel chips. Therefore, the percentage of small diameter stems 0.46 was used as the \%CHIPS estimate for both the feller buncher and skidder.

A total of 904.5 minutes (1,809 observations) of loader activity sampling was collected during the study harvest. Observed actions were classified into five different 
categories: Sorting Pulp, Running Chipper, Sorting SHWP, Loading Trailers, and Delay (Figure 10). The sum of the percentage of time sorting pulp and running the chipper was estimated to be 0.42 percent. This metric was used as the \%CHIPS estimate.

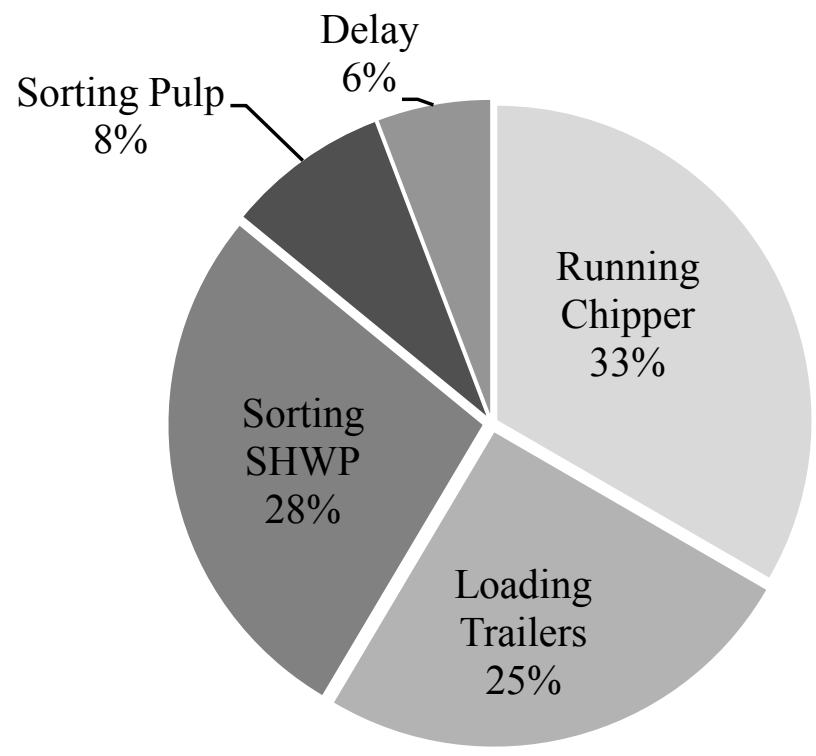

Figure 10. Loader activity sampling observed breakdown between five main categories

A substantial amount of additional production and harvest logistics data was collected throughout the study harvest. Much of this data has been purposefully left out of the main body of this research paper. Relevant production data and statistics are presented in table form in Appendix D.

\subsection{Observed System Costs}

This section outlines all the cost components: fixed equipment costs (3.5.1), variable equipment costs (3.5.2), labor costs (3.5.3), stumpage costs (3.5.4), and presents a summary of all the costs components and the total observed costs (3.5.5). 


\subsubsection{Fixed Equipment Costs}

This study harvest lasted a total of 27 working days. A total of 216 scheduled hours for the harvest equipment and 270 schedule hours for the log truck were observed (Table 10). A wide-spread and prolonged rain system moved into the region on the evening of the first day of the harvest study and resulted in rain delays totaling 9 days. Furthermore, there were two days of vacation time taken during the study harvest. Assuming that no rain delays or holidays occurred during the harvest, only16 days would have been needed to complete the harvest and, thus, 128 and $160 \mathrm{SMH}$ for the harvest equipment and log truck respectively. This lower figure, that does not include delays was used for this economic analysis.

Table 10. Fixed equipment cost figures showing the cost per scheduled mechanized hour, observed scheduled mechanized hours, fixed equipment cost for each piece and the entire equipment suite.

\begin{tabular}{|c|c|c|c|c|c|}
\hline Equipment & $\begin{array}{c}\text { SMH } \\
\text { w/o } \\
\text { delay }\end{array}$ & $\begin{array}{c}\text { SMH } \\
\text { w/ } \\
\text { delay }\end{array}$ & $\begin{array}{c}\text { Cost per } \\
\text { SMH }\end{array}$ & $\begin{array}{c}\text { Fixed cost } \\
\text { w/o delay }\end{array}$ & $\begin{array}{c}\text { Fixed cost w/ } \\
\text { delay }\end{array}$ \\
\hline Feller Buncher & 128 & 216 & $\$ 8.18$ & $\$ 1,046.47$ & $\$ 1,765.91$ \\
\hline Skidder & 128 & 216 & $\$ 6.60$ & $\$ 845.11$ & $\$ 1,426.12$ \\
\hline Loader & 128 & 216 & $\$ 6.21$ & $\$ 794.49$ & $\$ 1,340.70$ \\
\hline Chipper & 128 & 216 & $\$ 7.15$ & $\$ 915.10$ & $\$ 1,544.23$ \\
\hline Log Truck & 160 & 270 & $\$ 4.58$ & $\$ 733.55$ & $\$ 1,237.87$ \\
\hline Total & - & - & - & $\$ 4,334.72$ & $\$ 7,314.83$ \\
\hline
\end{tabular}

Using the estimations in Table 10, the total tons harvested $(1,066.66$ and 462.78 for the SWHP and fuel chips respectively), and the \%CHIPS estimates in Table 11, the fixed cost per ton of SWHP and fuel chips were calculated for each piece of harvest equipment. The cost per ton for the log truck was calculated as a function of miles traveled in section 3.5.3 below. 
Table 11. Estimation of the fixed equipment cost per ton for solid hardwood products and fuel chips.

\begin{tabular}{|c|c|c|c|c|c|c|}
\hline Equipment & $\begin{array}{c}\text { SMH } \\
\text { w/o } \\
\text { delay }\end{array}$ & \%CHIPS & $\begin{array}{c}\text { Tons } \\
\text { SHWP } \\
\text { per } \\
\text { SMH }\end{array}$ & $\begin{array}{c}\text { Tons } \\
\text { Fuel } \\
\text { Chips per } \\
\text { SMH }\end{array}$ & $\begin{array}{c}\text { Cost per } \\
\text { ton } \\
\text { SWHP }\end{array}$ & $\begin{array}{c}\text { Cost per } \\
\text { ton Fuel } \\
\text { Chips }\end{array}$ \\
\hline $\begin{array}{c}\text { Feller } \\
\text { Buncher }\end{array}$ & 128 & 0.46 & 15.57 & 7.78 & $\$ 0.52$ & $\$ 1.05$ \\
\hline Skidder & 128 & 0.46 & 15.57 & 7.78 & $\$ 0.42$ & $\$ 0.85$ \\
\hline Loader & 128 & 0.42 & 14.28 & 8.68 & $\$ 0.43$ & $\$ 0.71$ \\
\hline Chipper & 128 & 1.00 & 0.00 & 4.52 & $\$ 0.00$ & $\$ 1.98$ \\
\hline Total & - & - & - & & $\$ 1.38$ & $\$ 4.59$ \\
\hline
\end{tabular}

\subsubsection{Variable Equipment Costs}

The equipment in this study had observed PMH ranging from 19.23 hours up to 92.98 hours (Table 12). The equipment cost per PMH ranged from $\$ 21.72$ to $\$ 58.87$ per hour. The cost per hour was combined with the observed number of PMH for each piece of equipment to calculate the variable equipment cost for individual pieces of equipment and the entire equipment suite.

Table 12. Variable equipment cost figures showing observed number of productive hours $(\mathrm{PMH})$, cost per productive mechanized hour, variable equipment costs for each piece and the entire equipment suite.

\begin{tabular}{|c|c|c|c|}
\hline Equipment & PMH & $\begin{array}{c}\text { Cost per } \\
\text { PMH }\end{array}$ & Variable Cost \\
\hline Feller Buncher & 46.4 & $\$ 39.29$ & $\$ 1,823.12$ \\
\hline Skidder & 91.3 & $\$ 21.72$ & $\$ 1,983.04$ \\
\hline Loader & 57.7 & $\$ 22.66$ & $\$ 1,306.76$ \\
\hline Chipper & 19.2 & $\$ 58.87$ & $\$ 1,132.27$ \\
\hline Log Truck & 93.0 & $\$ 34.48$ & $\$ 3,205.88$ \\
\hline Total & - & - & $\$ 9,451.06$ \\
\hline
\end{tabular}

Using the estimations in Table 12, the total tons harvested $(1,066.66$ and 462.78 for the SWHP and fuel chips respectively), and the \%CHIPS estimates in Table 13, the 
variable cost per ton of SWHP and fuel chips were calculated for each piece of harvest equipment.

Table 13. Estimation of the variable costs per ton for both solid hardwood products and fuel chips.

\begin{tabular}{|c|c|c|c|c|c|c|}
\hline Equipment & PMH & $\%$ CHIPS & $\begin{array}{c}\text { Tons } \\
\text { SHWP } \\
\text { per } \\
\text { PMH }\end{array}$ & $\begin{array}{c}\text { Tons } \\
\text { Fuel } \\
\text { Chips } \\
\text { per PMH }\end{array}$ & $\begin{array}{c}\text { Variable } \\
\text { cost per } \\
\text { ton SWHP }\end{array}$ & $\begin{array}{c}\text { Variable } \\
\text { cost per } \\
\text { ton Fuel } \\
\text { Chips }\end{array}$ \\
\hline $\begin{array}{c}\text { Feller } \\
\text { Buncher }\end{array}$ & 46.4 & 0.46 & 42.96 & 21.45 & $\$ 0.91$ & $\$ 1.83$ \\
\hline Skidder & 91.3 & 0.46 & 21.83 & 10.90 & $\$ 0.99$ & $\$ 1.99$ \\
\hline Loader & 57.7 & .042 & 31.70 & 19.27 & $\$ 0.71$ & $\$ 1.18$ \\
\hline Chipper & 19.2 & 1.00 & 0.00 & 24.06 & $\$ 0.00$ & $\$ 2.45$ \\
\hline Total & - & - & - & & $\$ 2.62$ & $\$ 7.45$ \\
\hline
\end{tabular}

\subsubsection{Hauling Costs}

As reported in Table 10 and 12, the total cost of hauling observed in the study was $\$ 3,939.43$ dollars. This total cost was divided by the total observed distance traveled by the log truck $(3,341$ miles) to estimate the cost per mile $(\$ 1.18)$. Estimated cost per mile was divided by the average payload size (28.4 tons) to yield an estimated cost per tonmile (0.0415). The cost per ton-mile was multiplied by the round trip hauling distance to estimate the hauling cost per ton. These cost figures were estimated using the observed hauling data from this study (Table 14). A vast majority (87 percent) of the SHWP hauling was conducted by the log truck within the equipment suite. However, the scenarios presented in Sections 3.6 and 3.7 assume that all of the SHWP hauling was conducted by this log truck, thus some of the total hauling cost figure do not align exactly. 
Table 14. Distance to mills by road type, estimated round trip hauling time, and average speed.

\begin{tabular}{|c|c|c|c|c|c|c|c|c|}
\hline & $\begin{array}{c}\text { Saw } \\
\text { mill 1 }\end{array}$ & $\begin{array}{c}\text { Saw } \\
\text { mill 2 }\end{array}$ & $\begin{array}{c}\text { Saw } \\
\text { mill 3 }\end{array}$ & $\begin{array}{c}\text { Saw } \\
\text { mill 4* }\end{array}$ & $\begin{array}{c}\text { Saw } \\
\text { mill 5 }\end{array}$ & $\begin{array}{c}\text { Saw } \\
\text { mill 6* }\end{array}$ & $\begin{array}{c}\text { Saw } \\
\text { mill 7 }\end{array}$ & Average \\
\hline $\begin{array}{c}\text { Woods road } \\
\text { (miles, one- } \\
\text { way) }\end{array}$ & 0.05 & 0.05 & 0.05 & 0.05 & 0.05 & 0.05 & 0.05 & 0.05 \\
\hline $\begin{array}{c}\text { Asphalt 2-way } \\
\text { (miles one- } \\
\text { way) }\end{array}$ & 1.8 & 1.8 & 1.8 & 4.9 & 4.6 & 4.1 & 4.1 & 3.3 \\
\hline $\begin{array}{c}\text { Highway } \\
\text { (miles one- } \\
\text { way) }\end{array}$ & 12 & 8.1 & 11.3 & 7.9 & 8.9 & 24.2 & 25 & 13.9 \\
\hline $\begin{array}{c}\text { Interstate } \\
\text { (miles one- } \\
\text { way) }\end{array}$ & 43.3 & 24.1 & 19 & 74.6 & 83.3 & 49.2 & 36.5 & 47.1 \\
\hline $\begin{array}{c}\text { Total roundtrip } \\
\text { distance } \\
\text { (miles) }\end{array}$ & 114.4 & 68.2 & 64.4 & 175.0 & 193.8 & 155.2 & 131.4 & $98.3 * *$ \\
\hline $\begin{array}{c}\text { Round trip } \\
\text { hauling (hours) }\end{array}$ & 1.90 & 1.16 & 1.13 & 2.84 & 3.13 & 2.67 & 2.32 & $1.53 * *$ \\
\hline $\begin{array}{c}\text { Loading, } \\
\text { unloading, } \\
\text { securing } \\
\text { straps, } \\
\text { weighing } \\
\text { (hours) }\end{array}$ & 1.12 & 1.12 & 1.12 & 1.12 & 1.12 & 1.12 & 1.12 & 1.12 \\
\hline $\begin{array}{c}\text { Average speed } \\
\text { (mph) }\end{array}$ & 37.8 & 29.9 & 28.6 & 44.2 & 45.6 & 40.9 & 38.2 & $36.4 * *$ \\
\hline
\end{tabular}

*Loads taken to mill 4 and mill 6 were hauled by trucks owned by third party log trucks rather than the log truck included in the equipment suite, thus the cost of hauling these loads is not included in the cost structure.

**Indicate a weighted average

Transportation of fuel chips was conducted by a contracted hauling service who received $\$ 12.00$ per ton to haul the fuel chips approximately 160 miles round trip. The cost of this hauling $(\$ 5,553.36)$ was not bore directly by the operation, but rather through a reduction in earned revenue. Assuming that the cost of owning and operating a chip van is the same as a logging truck, it was estimated that internalizing a chip van into logging operation would have added approximately $\$ 3,776.07$ dollars to the total harvest 
costs. This additional cost was less than the reduction of revenues, thus providing evidence that, it in this case, it was economically justifiable for the logging operation to internalize a chip van into the equipment suite. Internalizing the chip van would have increased total revenue to the operation by an estimated $\$ 1,777.29$ dollars. It was estimated that the chip van would cost the operation approximately $\$ 0.0472$ per ton-mile to operate.

\subsubsection{Labor Costs}

Labor rates used by the logging operation were daily flat wages. The operator paid each member of the crew $\$ 150.00$ dollars each day for the entire harvest. The crew size varied between 4 and 5 people over the course of the study harvest. A total of 73 work days were observed by the crew over the harvest, thus a total of $\$ 10,950.00$ dollars in wages were paid. This method was used because the crew had an unusually long daily commute to the site and was unsure of the expected yields due to the additional requirements of working with the research team. Paying the crew a daily wage is not the normal method used by this logging crew. Typically, the operator pays the crew a rate based on the volume $(\$ 12.00$ per MBF) that is harvested. Assuming that this approach was used the labor costs of this operation would have only been $\$ 9,204.00$ dollars or $\$ 1,746.00$ (16 percent) less.

This study assumed that the labor costs were equally distributed between for both products on a per ton basis. Total labor costs $(\$ 10,950)$ were divided by total tonnage $(1,529.44$ tons $)$ of both products pooled together to estimate the labor cost per ton $(\$ 7.16)$ for both products. 


\subsubsection{Stumpage Costs}

Only one bid was submitted for each of the two replications due to the equipment requirements built into the bid contract. The stumpage for two 15 acres tracts was $\$ 1,000.00$ and $\$ 4,593.00$ respectively. When compared to the inventoried volume reported on the stumpage contract the harvest rights were sold for about $\$ 32$ per MBF, much lower than market rate. To make the economic analysis more realistic, stumpage prices for the region as reported by the Missouri Department of Conservation, Forestry Division stumpage price report Vol. 19 No. 2 report for April-June 2009 was referenced. This report indicated that mixed oak stumpage prices across Missouri were averaging $\$ 140$ per MBF in early summer of 2009 (MDC, April-June 2009). Stumpage was lower than normal because the logger was unsure of the additional costs associated with the data collection process and, secondly, the logger had to travel a longer distance to the study site each day, thus, adding to operational expenses.

Since the discrepancy between market stumpage and the observed stumpage was so great and would result in an artificially low breakeven cost point if the observed rate was used, an assumed market stumpage rate of $\$ 100$ per MBF will be used for the analysis. This figure is based off of stumpage rates reported in the MDC April-June report, discussions with foresters in the area and represents a conservative stumpage rate for the area at that time. Since 106.2 MBF was estimated to be on the site in the preharvest inventory and $\$ 100 / \mathrm{MBF}$ was used as the stumpage rate, a total stumpage price of $\$ 10,620$ dollars was used for the SHWP. Since the observed volume of SHWP removed from the site was 1066.66 tons (173 MBF), the stumpage cost was estimated to be $\$ 9.96$ per ton, or $\$ 61.37$ per MBF. 
Attaching a stumpage cost to the fuel chips is less straight forward than the SHWP. Little insight was found in the literature review as to how this material should be paid for by the logger and introduced into cost estimations. A per ton payment on the fuel chips as it is delivered was chosen as the approach because 1) the pre-harvest inventory did not yield accurate estimates, and 2) the amount of fuel chips removed from a harvest job is likely to vary considerably based on many factors such as ability to skid whole trees or tree length without damage, patchiness of small diameter trees, and SHWP product specifications that can yield many short ends of bucked logs at the landing that can be easily processed into fuel chips. It was estimated that the logger would give the landowner $\$ 5.00$ per ton for all the fuel chips material delivered to the mill. Using this assumed fuel chips stumpage rate, the operator would have paid the landowner $\$ 2,313.90$ dollars for the fuel chips material.

\subsubsection{Cost Summary}

This sub-section compiles all the fixed and variable costs presented in section 3.4 and shows them in charts and tables. The total observed costs of the harvest operation was estimated to be $\$ 37,669.68$ (Table 15 ). Stumpage and labor costs captured the greatest share of harvest costs, 35 and 29 percent, respectively (Figure 11).

Table 15. Observed variable, fixed and total costs for equipment, stumpage and labor.

\begin{tabular}{|c|c|c|c|}
\hline Component & Variable Cost & Fixed Cost & Total Cost \\
\hline Feller Buncher & $\$ 1,823.12$ & $\$ 1,046.47$ & $\$ 2,869.59$ \\
\hline Skidder & $\$ 1,983.04$ & $\$ 845.11$ & $\$ 2,828.15$ \\
\hline Loader & $\$ 1,306.76$ & $\$ 794.49$ & $\$ 2,101.25$ \\
\hline Chipper & $\$ 1,132.27$ & $\$ 915.10$ & $\$ 2,047.37$ \\
\hline Log Truck & $\$ 3,205.88$ & $\$ 733.55$ & $\$ 3,939.43$ \\
\hline Labor & $\$ 10,950.00$ & na & $\$ 10,950.00$ \\
\hline Stumpage & na & $\$ 12,933.90$ & $\$ 12,933.90$ \\
\hline Total & $\$ 20,401.06$ & $\$ 17,268.62$ & $\$ 37,669.68$ \\
\hline
\end{tabular}




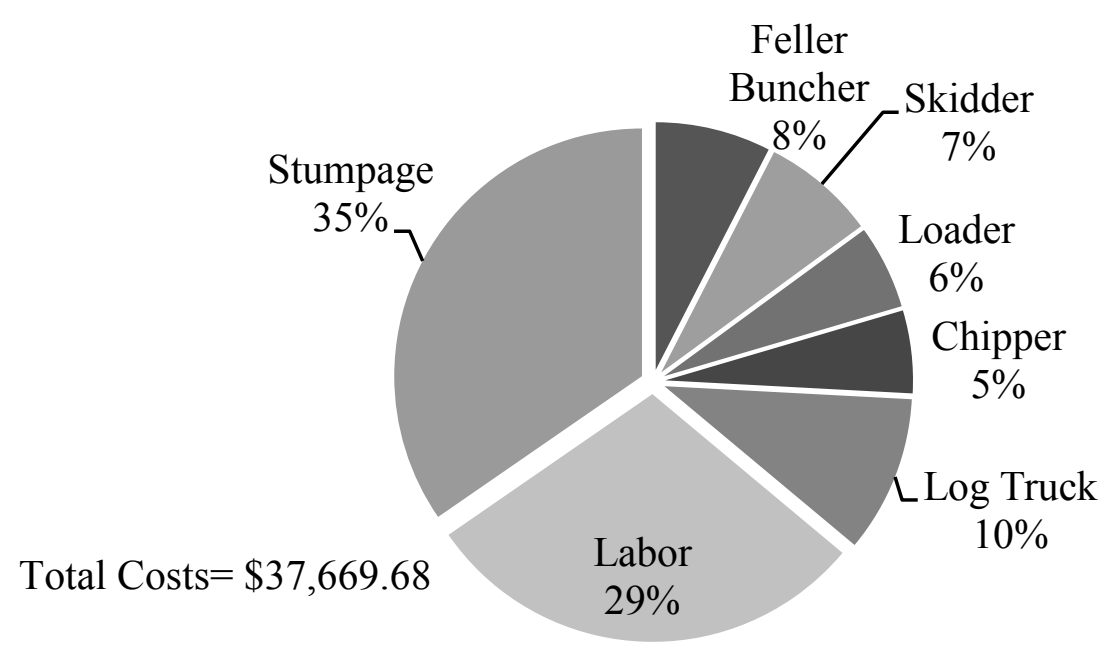

Figure 11. Total observed cost components.

The total cost per ton for the harvest was estimated to be $\$ 25.33$ and $\$ 28.92$, for the SHWP and fuel chips, respectively, assuming a 100 mile round trip (Table 16). Assuming that the contract hauling service was used the total cost per ton for the fuel chips were estimated to be $\$ 36.20$. The estimated cost to harvest, skid to the landing, process, and load into a trailer or chip van (stumpage and hauling removed) was estimated to be $\$ 11.17$ and $\$ 19.20$ dollars, respectively.

Table 16. Estimated cost per ton for each component of the study harvest for both solid hardwood products and fuel chips.

\begin{tabular}{|c|c|c|c|}
\hline Component & $\begin{array}{c}\text { Cost per ton } \\
\text { of SHWP }\end{array}$ & $\begin{array}{c}\text { Cost per ton of } \\
\text { Fuel Chips }\end{array}$ & $\begin{array}{c}\text { Cost per ton of } \\
\text { Fuel Chips** }\end{array}$ \\
\hline Feller Buncher & $\$ 1.44$ & $\$ 2.88$ & $\$ 2.88$ \\
\hline Skidder & $\$ 1.42$ & $\$ 2.84$ & $\$ 2.84$ \\
\hline Loader & $\$ 1.15$ & $\$ 1.89$ & $\$ 1.89$ \\
\hline Chipper & $\$ 0.00$ & $\$ 4.42$ & $\$ 4.42$ \\
\hline Hauling* & $\$ 4.21$ & $\$ 4.72$ & $\$ 12.00^{* *}$ \\
\hline Labor & $\$ 7.16$ & $\$ 7.16$ & $\$ 7.16$ \\
\hline Stumpage & $\$ 9.95$ & $\$ 5.00$ & $\$ 5.00$ \\
\hline Total & $\$ 25.33$ & $\$ 28.92$ & $\$ 36.20$ \\
\hline
\end{tabular}

*Assumes that hauling is internalized into the equipment suite and that round trip hauling distance is 100 miles

$* *$ The contract chip van hauler received $\$ 12.00$ per ton to deliver the fuel chips 


\subsection{Harvesting System Productivity}

This section presents to two different harvest systems to illustrate the cost dynamics of the study harvest. Section 3.6.1 uses the revenue and costs estimates presented in section 3.2 through 3.5 to estimate profit/loss of the "integrated system" in balance sheet format. Section 3.6.2 presents a similar profit/loss balance sheet for a hypothetical harvest system that only aims to harvest SHWP. This new system is referred to as the "merchantable system". Section 3.6.3 compares the two systems to determine how the additional efforts to harvest fuel chips changed the profit/loss of this study harvest system.

\subsubsection{Profit/loss of the integrated system}

The production rates presented in sections 3.4.1 through 3.4.5 were used to estimate productivity for each cost item included in the integrated system (Figure 12). The total cost per ton for SHWP and fuel chips are $\$ 25.33$ and $\$ 36.20$ respectively (Table 17).

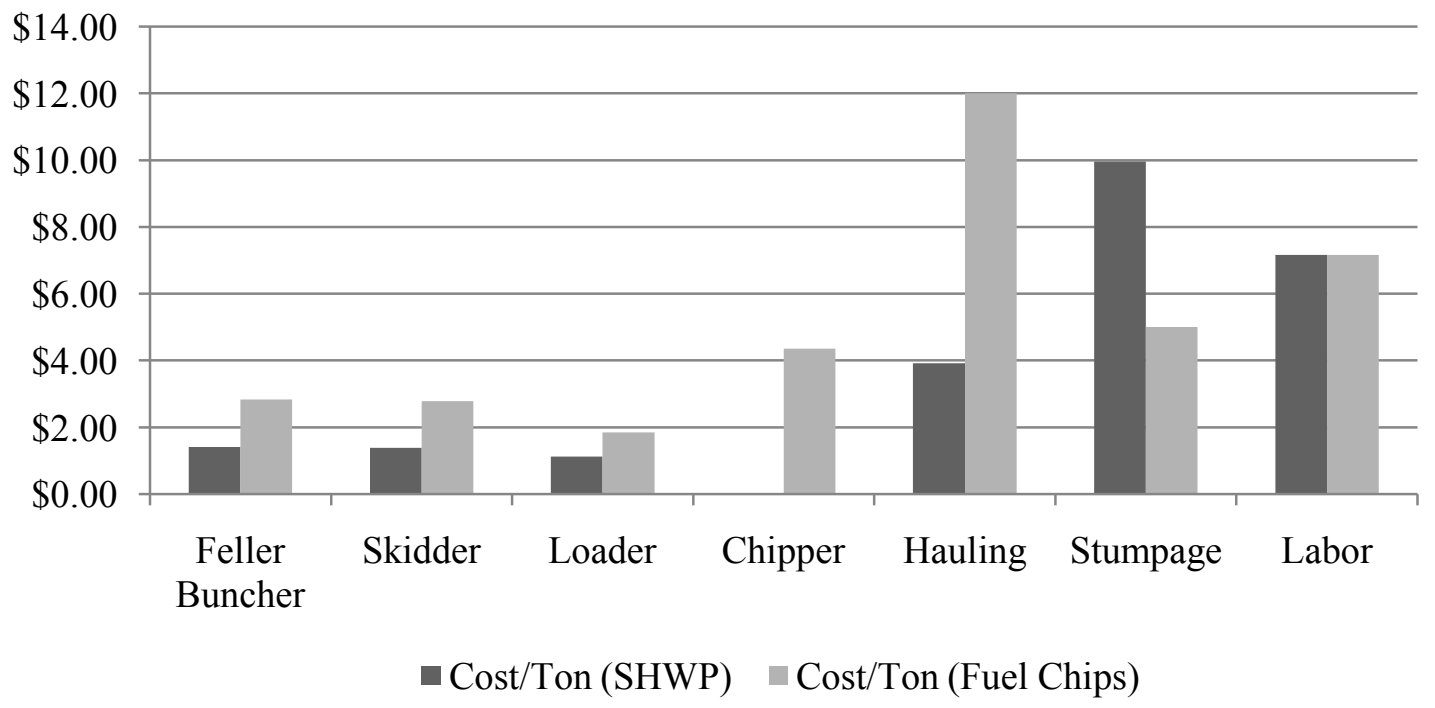

Figure 12. Integrated system costs per ton for each component of the harvest 
Table 17. Summary of costs observed during the integrated system study harvest.

\begin{tabular}{|c|c|c|c|c|c|c|}
\hline Equipment & SMH & $\begin{array}{c}\text { Cost per } \\
\text { SMH }\end{array}$ & PMH & $\begin{array}{c}\text { Cost per } \\
\text { PMH }\end{array}$ & $\begin{array}{c}\text { Cost per } \\
\text { ton } \\
\text { of } \\
\text { SHWP }\end{array}$ & $\begin{array}{c}\text { Cost per } \\
\text { ton of } \\
\text { Fuel } \\
\text { Chips }\end{array}$ \\
\hline Feller Buncher & 128 & $\$ 8.18$ & 46.4 & $\$ 39.29$ & $\$ 1.44$ & $\$ 2.88$ \\
\hline Skidder & 128 & $\$ 6.60$ & 91.3 & $\$ 21.72$ & $\$ 1.42$ & $\$ 2.84$ \\
\hline Loader & 128 & $\$ 6.21$ & 57.7 & $\$ 22.66$ & $\$ 1.15$ & $\$ 1.89$ \\
\hline Chipper & 128 & $\$ 7.15$ & 19.2 & $\$ 58.87$ & $\$ 0.00$ & $\$ 4.42$ \\
\hline Hauling & 160 & $\$ 4.58$ & 93.0 & $\$ 34.48$ & $\$ 4.21 *$ & $12.00 * *$ \\
\hline Labor & - & - & - & - & $\$ 7.16$ & $\$ 7.16$ \\
\hline Stumpage & - & - & - & - & $\$ 9.95$ & $\$ 5.00$ \\
\hline Total & - & - & - & - & $\$ 25.33$ & $\$ 36.20$ \\
\hline
\end{tabular}

*Assumed 100 mile round trip hauling distance.

**Hauling was conducted by a contract chip van hauler. This contactor was paid $\$ 12.00$ from each load of fuel chips.

The observed prices for the two products were $\$ 32.64$ and $\$ 26.00$ per ton. The SHWP sold for a price greater than its breakeven price and the fuel chips sold for a price lower than its breakeven price. This resulted in a net profit of $\$ 7,797.28$ for the SHWP and a net loss of $\$-4,720.36$ for the fuel chips. Ultimately, the profits from the SHWP were large enough to offset the losses endured from harvesting the fuel chips, leading to a net profit of $\$ 3,076.92$ for the entire integrated system (Table 18).

Table 18. Balance sheet for the integrated system that shows the profit/loss per ton and the net revenue

\begin{tabular}{|c|c|c|}
\hline & SHWP & Fuel Chips \\
\hline Revenue /ton & $\$ 32.64$ & $\$ 26.00$ \\
\hline Harvest Cost per ton ( - ) & $\$ 11.17$ & $\$ 19.20$ \\
\hline Hauling cost per ton ( - ) & $\$ 4.21$ & $\$ 12.00$ \\
\hline Stumpage cost per ton ( - ) & $\$ 9.95$ & $\$ 5.00$ \\
\hline Profit per Ton ( $)$ & $\$ 7.31$ & $\$-10.20$ \\
\hline Total Tons ( $*)$ & $1,066.66$ & 462.78 \\
\hline Profit/loss ( $)$ & $\$ 7,797.28$ & $\$-4,720.36$ \\
\hline Grand Total Profit/loss (+) & \multicolumn{2}{|c|}{$\$ 3,076.92$} \\
\hline
\end{tabular}


Assuming that the chip van was internalized into the harvest system the fuel chips breakeven price would become $\$ 28.92$ ton, still higher than the price per ton of fuel chips received resulting in a per ton loss of $\$ 2.92$ per ton. This assumptions yields loss from fuel chips of $\$-1,351.32$ and a grand total profit of $\$ 6,445.96$.

\subsubsection{Profit/loss of the "merchantable system"}

Several key assumptions were made to produce cost estimates for a merchantable system (Figure 13). First, the chipper, fuel chips stumpage and chip van hauling were excluded from the cost structure. Second, the PMH for the harvest equipment was reduced by the \%CHIPS figure. Finally, labor costs and the SMH were reduced by 30.2 percent, thus assuming that the harvest would have taken less time to complete if no fuel chips were harvested. The 30.2 percent figure was determined based on the percentage of the total tons harvested that were derived from fuel chips. The total SHWP cost per ton for the merchantable system is estimated to be $\$ 25.70$ per ton (Table 19).

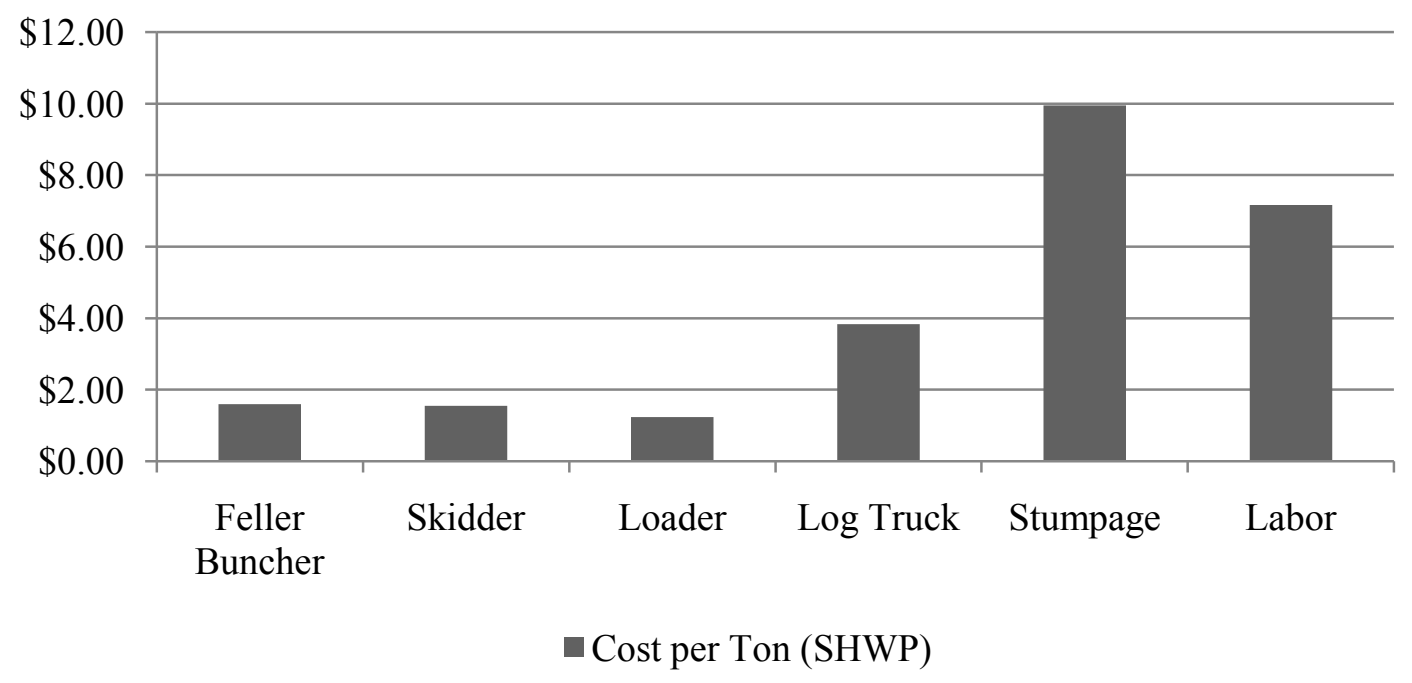

Figure 13. Cost of all components assuming that only the solid hardwood products were harvested, "merchantable system". 
Table 19. Merchantable system estimated variable equipment cost and production rates

\begin{tabular}{|c|c|c|c|c|c|}
\hline Equipment & $\begin{array}{c}\text { Reduced } \\
\text { SMH }\end{array}$ & $\begin{array}{c}\text { Cost per } \\
\text { SMH }\end{array}$ & $\begin{array}{c}\text { Reduced } \\
\text { PMH }\end{array}$ & $\begin{array}{c}\text { Cost per } \\
\text { PMH }\end{array}$ & $\begin{array}{c}\text { Cost per ton } \\
\text { of SHWP }\end{array}$ \\
\hline Feller Buncher & 89 & $\$ 8.18$ & 24.83 & $\$ 39.29$ & $\$ 1.60$ \\
\hline Skidder & 89 & $\$ 6.60$ & 48.86 & $\$ 21.72$ & $\$ 1.55$ \\
\hline Loader & 89 & $\$ 6.21$ & 33.65 & $\$ 22.66$ & $\$ 1.23$ \\
\hline Hauling & 112 & $\$ 4.58$ & 93.0 & $\$ 34.48$ & $\$ 4.21^{*}$ \\
\hline Labor & - & - & - & - & $\$ 7.16$ \\
\hline Stumpage & - & - & - & - & $\$ 9.95$ \\
\hline Total & - & - & - & - & $\$ 25.70$ \\
\hline
\end{tabular}

*Assumed 100 mile round trip hauling distance.

The breakeven price for SHWP in the merchantable system was estimated to be $\$ 25.70$ per ton, meaning that if the price per ton received is greater than $\$ 25.70$ per ton then the system operated with a net profit. In this study harvest the observed revenues per ton were $\$ 32.64$, thus, the merchantable system was able to better the breakeven point and earn a net profit of $\$ 7,402.62$ (Table 20).

Table 20. Balance sheet of the Merchantable System showing this profit per ton and the net profits of this assumed system.

\begin{tabular}{|c|c|}
\hline & SHWP \\
\hline Revenue /ton & $\$ 32.64$ \\
\hline Harvest Cost per ton $(-)$ & $\$ 11.54$ \\
\hline Hauling cost per ton ( - ) & $\$ 4.21$ \\
\hline Stumpage cost per ton ( - ) & $\$ 9.95$ \\
\hline Profit per Ton ( =) & $\$ 6.94$ \\
\hline Total Tons $(*)$ & $1,066.66$ \\
\hline Profit/loss ( $)$ ) & $\$ 7,402.62$ \\
\hline
\end{tabular}

\subsubsection{Differences between integrated and merchantable systems}

Comparing the total profits of the "merchantable system" to the total profits of the "integrated system" shows that a larger grand total profit would have been realized using merchantable system. This is attributed to the high cost of production and low selling prices of the fuel chips (Figure 14). Each ton of fuel chips resulted in a net loss of $\$ 10.20$. These results show that harvesting fuel chips in the Missouri Ozarks using this 
methodology is not economically feasible at the current prices. The estimated total costs and revenues per acre for the integrated system yield a $\$ 103.02$ profit per acre and the merchantable system yields a $\$ 247.50$ per acre profit (Figure 15). Beyond the profit/loss change, the merchantable system had a lower cost outlay to operate because it requires less equipment. This reduces overhead expenses and the risk associated with owning expensive equipment. Furthermore, the cost of moving equipment from site to site would also be reduces if few pieces of equipment are owned by the operation. It is important to note that cost assumptions made throughout this study, especially stumpage price, greatly affected the cost structure of the harvest system and its balance sheet. Section 3.6 presents a sensitivity analysis and explores how changes in cost components result in different price per ton breakeven points.

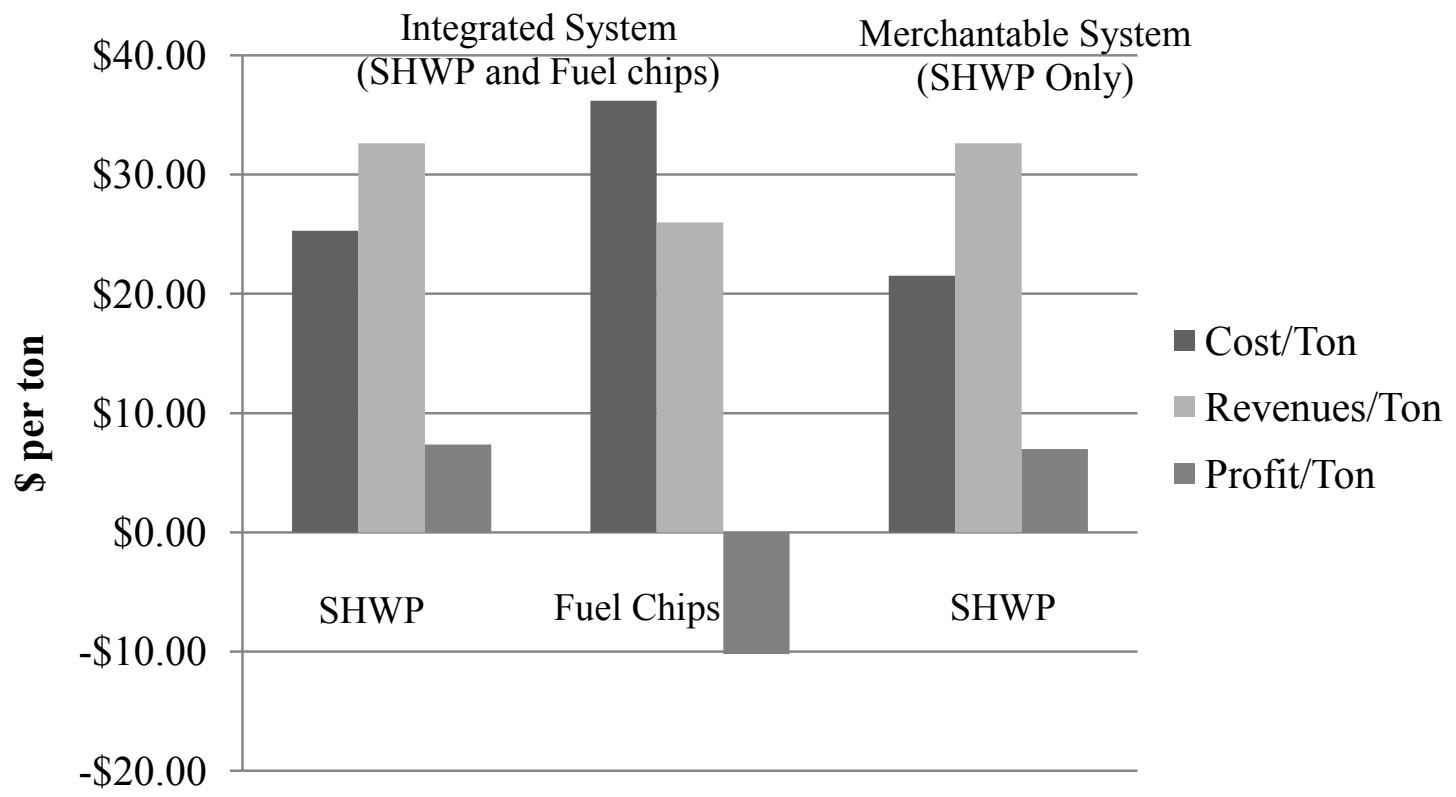

Figure 14. Comparison of the Integrated System's and Merchantable System's cost, revenue, and profit per ton for harvested products. 


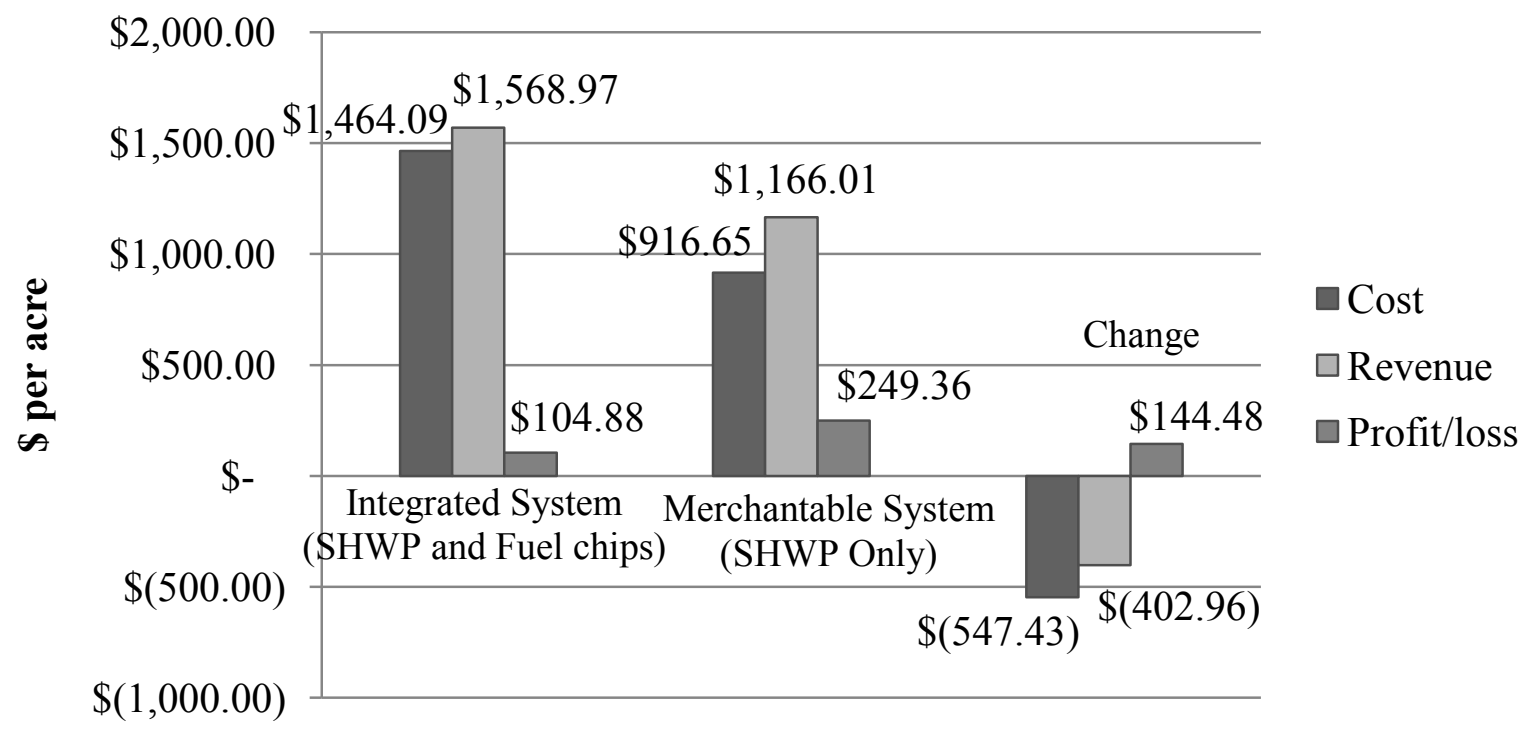

Figure 15. Effects on system cost, revenue, and profit/loss (cost per acre) of harvesting the "Integrated system" (solid hardwood products and fuel chips) and the "Merchantable system" (solid hardwood products only). The third column labeled "Change" shows the difference between these two systems.

\subsection{Sensitivity Analysis}

Section 3.6 outlines several different scenarios with different market conditions that could be faced by logging operators in the Ozarks. The effect of changing diesel fuel prices (3.7.1), changing equipment suite purchase price (3.7.2), changing hauling distance (3.7.3), and stumpage prices (3.7.4) on the total production cost per ton was determined. Section 3.7.5 examines the effect of a government subsidy on the harvest system's profit/loss.

\subsubsection{Scenario \#1 Changes in Fuel Prices}

Fuel costs are one of the key factors that determine the cost per PMH. Increasing fuel prices causes increases in the harvesting costs and the hauling costs, and thus the total cost per ton (Figure 16). This increase is assumed to not cause changes to stumpage 
or labor costs. The estimates presented in the previous sections used an assumed fuel price of $\$ 2.60$ per gallon for on-road diesel and $\$ 2.15$ per gallon off-road diesel to estimate the production costs. These assumed fuel prices resulted in production costs of $\$ 25.28$ and $\$ 28.78$ for the SHWP and fuel chips respectively (designated with a star $\underline{\sim}$ in Figure 16).

This analysis assumed that stumpage prices remain at $\$ 9.95$ and $\$ 5.00$ per ton for the SHWP and fuel chips, respectively. It was assumed that the cost per SMH of the equipment suite observed in the study harvest remained unchanged. It was also assumed that labor costs remained the same and added $\$ 7.16$ per ton for both products. Round trip hauling distance is assumed to be 100 miles. Finally, this scenario assumed that a chip van is internalized into the harvest system and hauling rates for the chip van are similar to the log truck with exception for the total payload capacity $\$ 28.35$ tons and $\$ 25.71$ tons, respectively. 


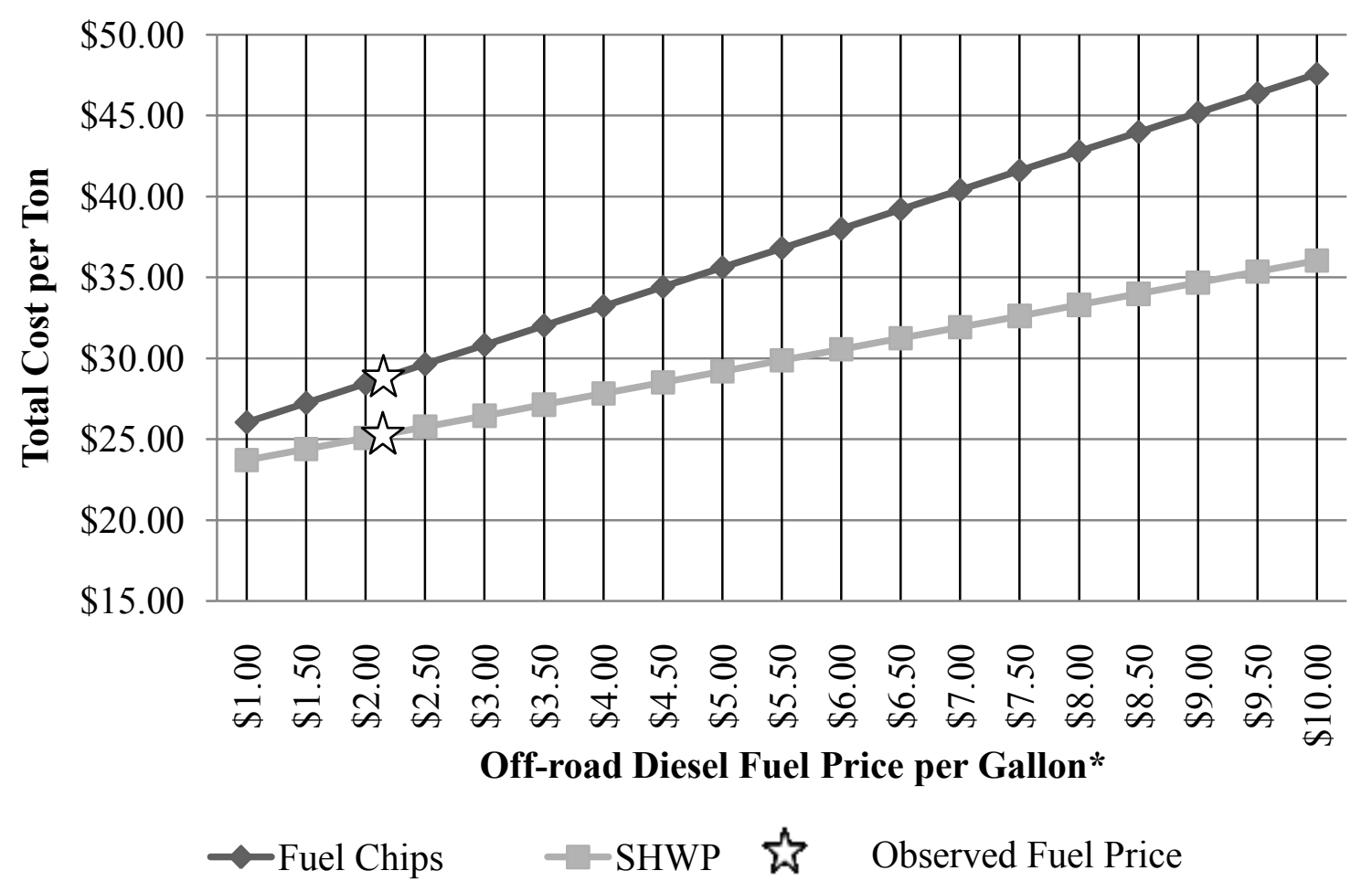

Figure 16. Sensitivity analysis of the total production cost per ton to increases in diesel fuel. Cost components include harvesting, labor, hauling (assumed 100 mile round trip), and stumpage at $\$ 9.95 /$ ton and $\$ 5.00 /$ ton for the solid hardwood products and fuel chips respectively.

*Off -road diesel was assumed to be $\$ 0.45$ less than on-road diesel.

An increase in diesel fuel prices from $\$ 2.50$ per gallon to $\$ 5.00$ per gallon, a $\$ 2.50$ dollar change resulted in a change in the total cost per ton from $\$ 25.76$ to $\$ 29.19$ per ton, a $\$ 3.43$ dollar change (13.3 percent change). This model suggested that a $\$ 0.50$ change in diesel prices has a magnified $\$ 0.69$ change in total production cost for SWHP, $\$ 0.28$ due to harvesting costs changes and $\$ 0.41$ due to hauling costs changes. The magnification was even more pronounced for fuel chips where a $\$ 0.50$ change in diesel fuel prices causes a $\$ 1.20$ increase to total production costs, $\$ 0.75$ due to harvesting cost changes and $\$ 0.45$ due to hauling cost changes. This difference in magnification is explanation for why the two lines in Figure 16 are separating from each other as the 
diesel fuel prices increase. The different change rates $(\$ 0.41$ and $\$ 0.45$ per ton) in the hauling costs are due to assumed payload capacities of 28.35 and 25.71 tons for the SHWP and fuel chips respectively. The slope of the SHWP price sensitivity line is estimated to be 1.37, while the slope of the fuel chips price sensitivity line is estimated to be 2.39 , further evidence that the fuel chips prices are more sensitive to changes in diesel fuel prices than the SHWP.

\subsubsection{Scenario \#2 Changes in Equipment Costs}

Purchase price of equipment plays the largest role in establishing the cost of ownership also known as the cost per SMH. All of the equipment utilized in this study harvest was purchased used at prices much lower than those of new equipment. Scenario 2 examines how increasing the total equipment suite purchase prices affects the cost of production. Dividing the total equipment suite purchase price between the different pieces of equipment was done based on pricing estimates provided by an equipment dealer in mid-Missouri in December 2009. As expected, changing the total cost of the equipment suite causes an increase in the total cost of production (Figure 17). The total equipment suite cost for the observed study harvest was approximately $\$ 275,000$ (designated with a star $\hat{w}$ in Figure 17). The allocation of the total cost between the pieces of equipment is different than the allocation used in this sensitivity analysis, thus the estimated costs per ton are slightly different.

This scenario assumed that fuel prices are $\$ 2.50$ per gallon for off-road diesel, stumpage prices remained constant at $\$ 9.95$ and $\$ 5.00$ per ton for the SHWP and fuel chips respectively, labor costs remain at $\$ 7.16$ per ton for both products. Finally, this scenario assumed that a chip van is internalized into the harvest system and hauling rates 
for the chip van are similar to the log truck with exception for the total payload capacity 28.35 tons and 25.71 tons respectively.

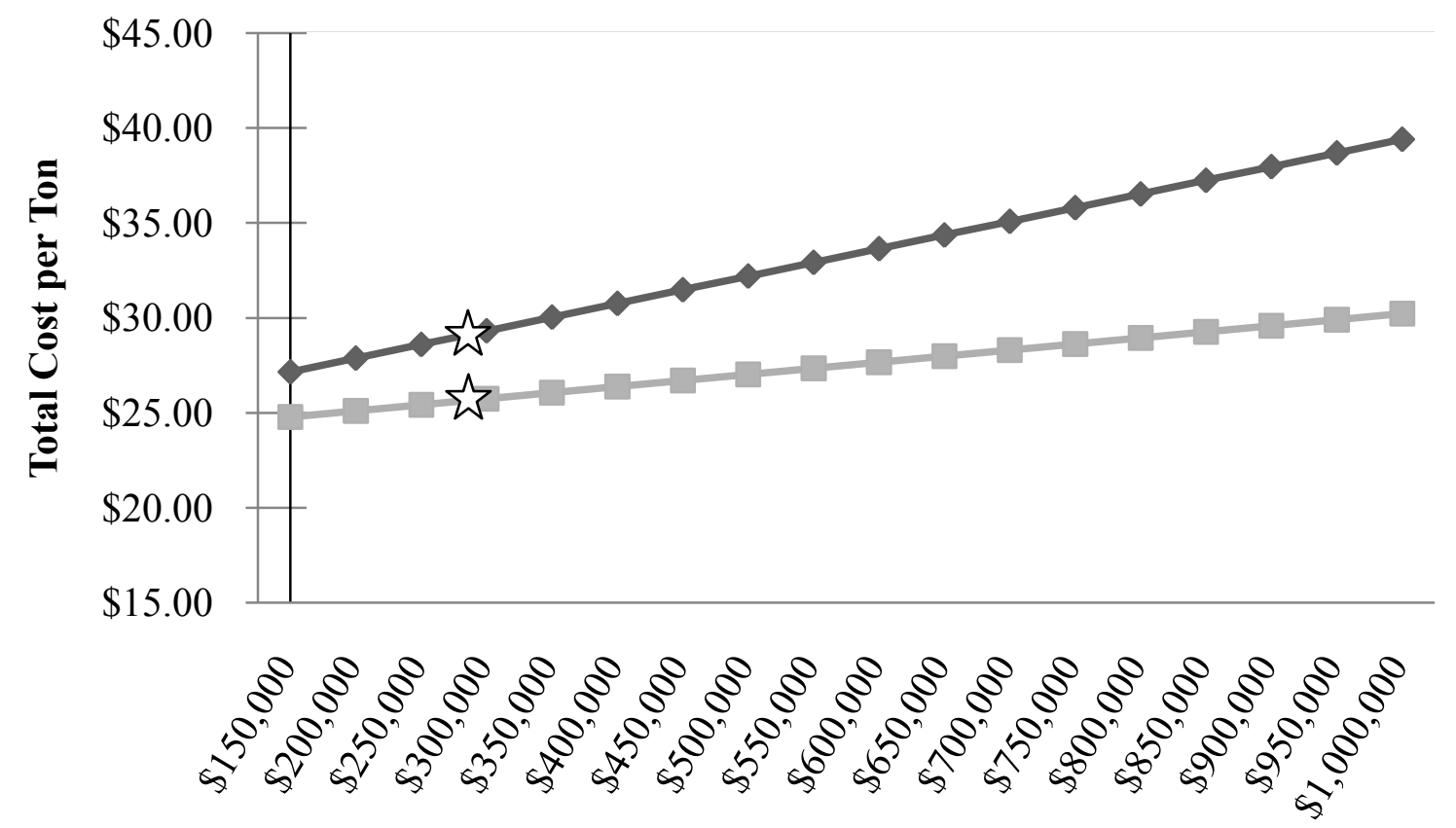

Equipment Suite Total Purchse Price

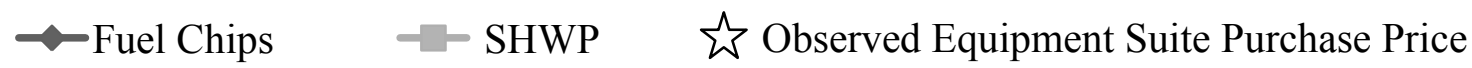

Figure 17. Sensitivity analysis of the total production cost per ton to increases in the equipment suite total purchase prices. Cost components include harvesting, labor, hauling (assumed 100 mile round trip), and stumpage at $\$ 9.95 /$ ton and $\$ 5.00 /$ ton for the solid hardwood products and fuel chips respectively. This analysis assumes fuel price of $\$ 2.50$ per gallon of off-road diesel.

Increasing the equipment suite purchase price from $\$ 250,000$ to $\$ 300,000$ dollars, a $\$ 50,000$ change, causes an increase in the total production cost by $\$ 0.32$ and $\$ 0.72$ per ton for the SHWP and fuel chips respectively. The fuel chips exhibited a greater response (more sensitive) to changes in equipment purchase prices. This result was primarily due to the addition of a single piece of equipment, the chipper, which works 
solely with fuel chips. Thus, the cost of this chipper was entirely placed on the fuel chips and not shared by the SWHP.

The slopes of these lines are less pronounced than those that measure the sensitivity to fuel prices. This was due to the ability to spread the equipment costs across an entire year of scheduled hours of operation, SMH. Thus increasing the equipment suite size to a more expensive suite appears to be feasible. What is not quantified here is the additional risk that the operator would take by increasing the fixed cost of operation. For example, purchasing new equipment that experiences breakdowns or is underutilized adds to the total production costs even though it is not contributing to the productivity of the system.

\subsubsection{Scenario \#3 Changes in Hauling Distances}

Hauling distance was a primary component that affected the total hauling costs. Scenario 3 examines how changing the assumed round trip hauling distance affects the total production cost per ton. As expected, as the round trip hauling distance increased it caused the total cost per ton to also increase (Figure 18). The roundtrip hauling distance used throughout the study harvest was assumed to be 100 miles (designated with a star $\Sigma^{\wedge}$ in Figure 18).

This scenario assumed that fuel prices were $\$ 2.50$ per gallon for off-road diesel, stumpage prices remain constant at $\$ 9.95$ and $\$ 5.00$ per ton for the SHWP and fuel chips respectively, labor costs remain at $\$ 7.16$ per ton for both products. It was assumed that the cost per SMH of the equipment suite observed in the study harvest remains unchanged. This scenario also assumed that a chip van was internalized into the harvest 
system and hauling rates for the chip van are similar to the log truck with exception for the total payload capacity 28.35 tons and 25.71 tons, respectively.

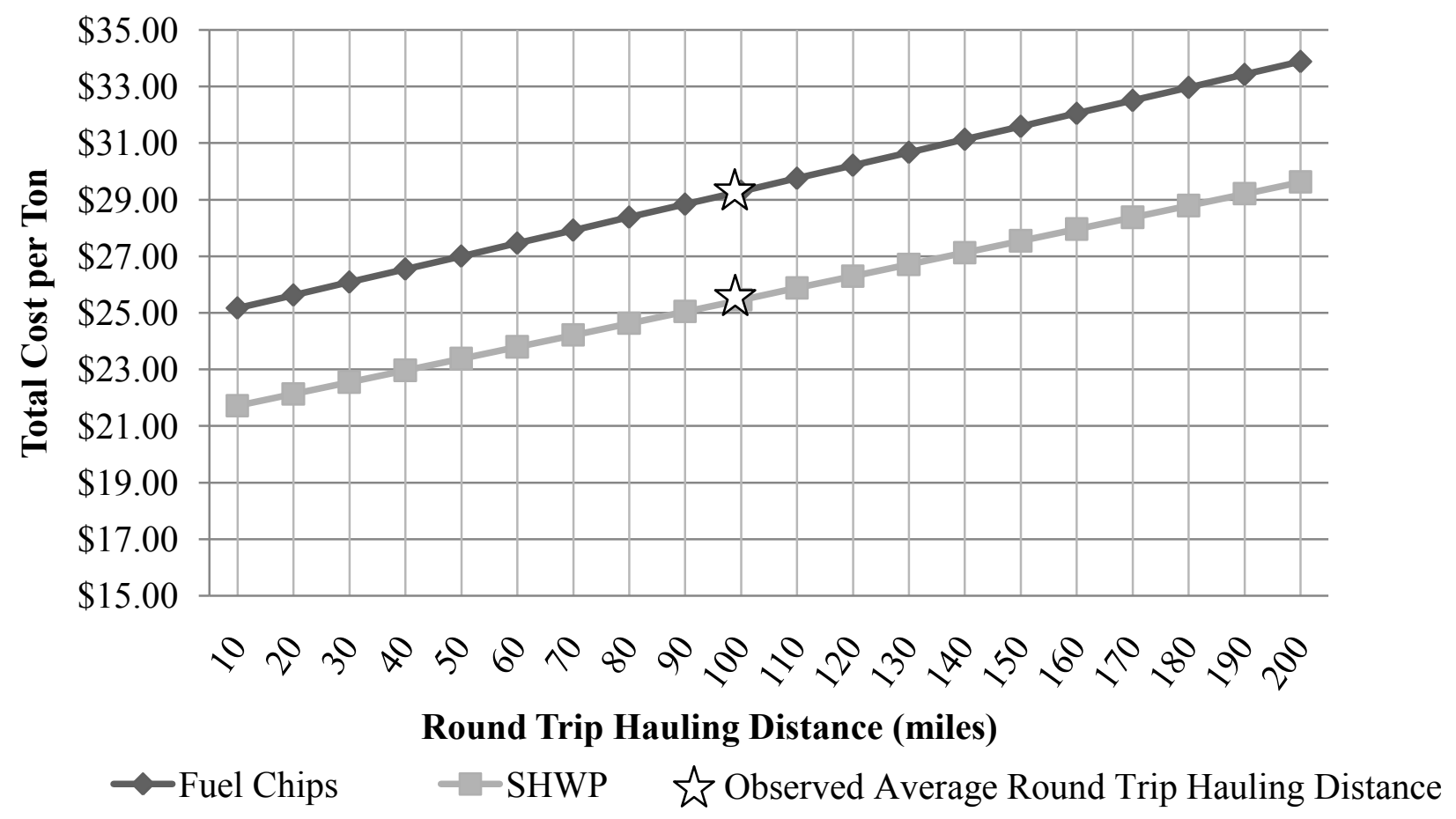

Figure 18. Sensitivity analysis of the total production cost per ton to changes to the roundtrip hauling distance. Cost components include harvesting, labor, hauling, and stumpage at $\$ 9.95 /$ ton and $\$ 5.00 /$ ton for the solid hardwood products and fuel chips respectively. This analysis assumed fuel price of $\$ 2.50$ per gallon of off-road diesel.

Increasing the round trip hauling distance from 50 to 100 miles caused the total production cost per ton to increase $\$ 2.08$ and $\$ 2.30$ for the SWHP and fuel chips, respectively. The difference between the two products is a function of payload capacity (28.35 and 25.71tons) since it was assumed that the log truck and chip van have the same total cost mile $\$ 1.18$. The slopes of the sensitivity analysis lines are the cost per ton-mile reported in section 3.4.3 of 0.0419 and 0.0459 for the two products respectively. Since the slope of the fuel chips is slightly greater than the SHWP it indicates that hauling this product is more sensitive to hauling distances. 


\subsubsection{Scenario \#4 Change in Stumpage Costs}

Stumpage prices comprised the largest single item of the total cost of per ton in this study harvest and caused the total cost per ton to increase as stumpage costs increased (Figure 19). Stumpage prices can be highly variable based on region, markets, stand conditions, and special scenarios such as salvage operations due to blow down or ice damage should be evaluated in the future. The SHWP stumpage prices observed in the study harvest was approximately $\$ 61.37$ per MBF or $\$ 9.95 /$ ton (designated with a star

$\mathcal{L}^{2}$ in Figure 19). The assumed stumpage prices paid was $\$ 100$ per MBF, but the actual harvested SHWP was greater than the inventoried amount which the bid was based on, thus the actual stumpage rate declined.

This scenario assumed that fuel prices are $\$ 2.50$ per gallon for off-road diesel, labor costs remain at $\$ 7.16$ per ton for both products and the cost per SMH of the equipment suite observed in the study harvest remains unchanged. This scenario also assumes that a chip van was internalized into the harvest system and hauling rates for the chip van are similar to the log truck with exception for the total payload capacity 28.35 tons and 25.71 tons, respectively. 


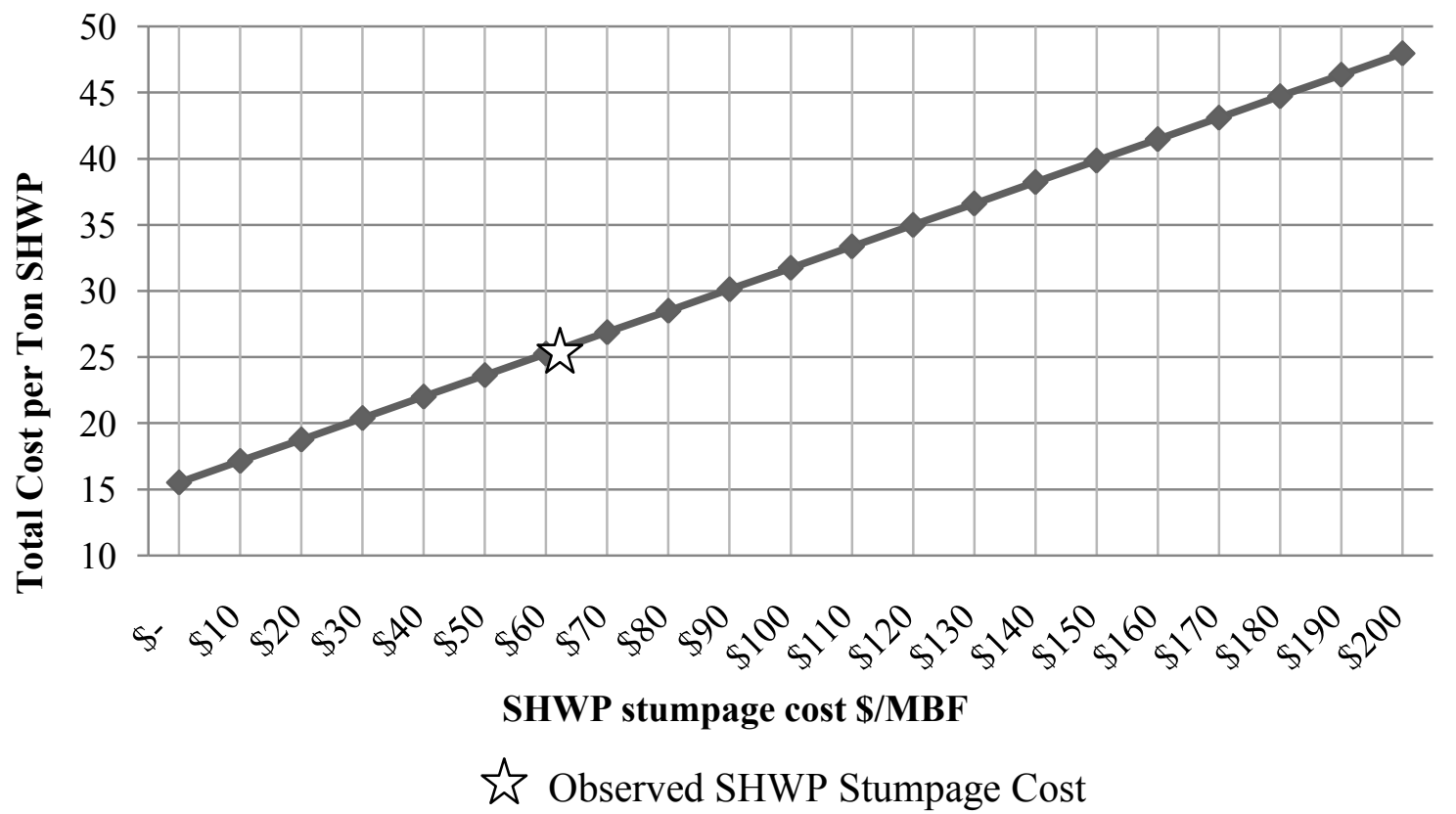

Figure 19. Sensitivity analysis of total production cost per ton to change to the stumpage cost paid for SWHP. Other cost components held constant include harvesting, labor, and hauling. This analysis assumes a fuel price of $\$ 2.50$ per gallon of off-road diesel.

Increases in stumpage cost are directly added to the total cost of production. Thus increasing the stumpage cost per ton by one dollar results in an increase in total cost per ton by one dollar. However, the $\mathrm{x}$-axis is measured in MBF, thus a conversion must be made to get to cost per ton. The conversion factor of 0.16221 is multiplied by the cost per MBF to change it to cost per ton. The slope of this sensitivity line is this conversion factor $(0.16221)$ since stumpage costs are a direct component of the total cost of production and have no direct interaction with equipment or labor costs.

Stumpage cost on the fuel chips followed similar dynamics (Figure 20). One key difference between products in the stumpage sensitivity analysis was that the fuel chips stumpage was already expressed in tons. Thus, a conversion factor was not needed and the slope of the line is exactly 1.0. The fuel chips stumpage prices observed in the study 
harvest was assumed to be $\$ 5.00$ per ton (designated with a star $\underline{h}$ in Figure 20). All the assumptions made for the SWHP stumpage sensitivity analysis remain for the fuel chips stumpage sensitivity analysis as well.

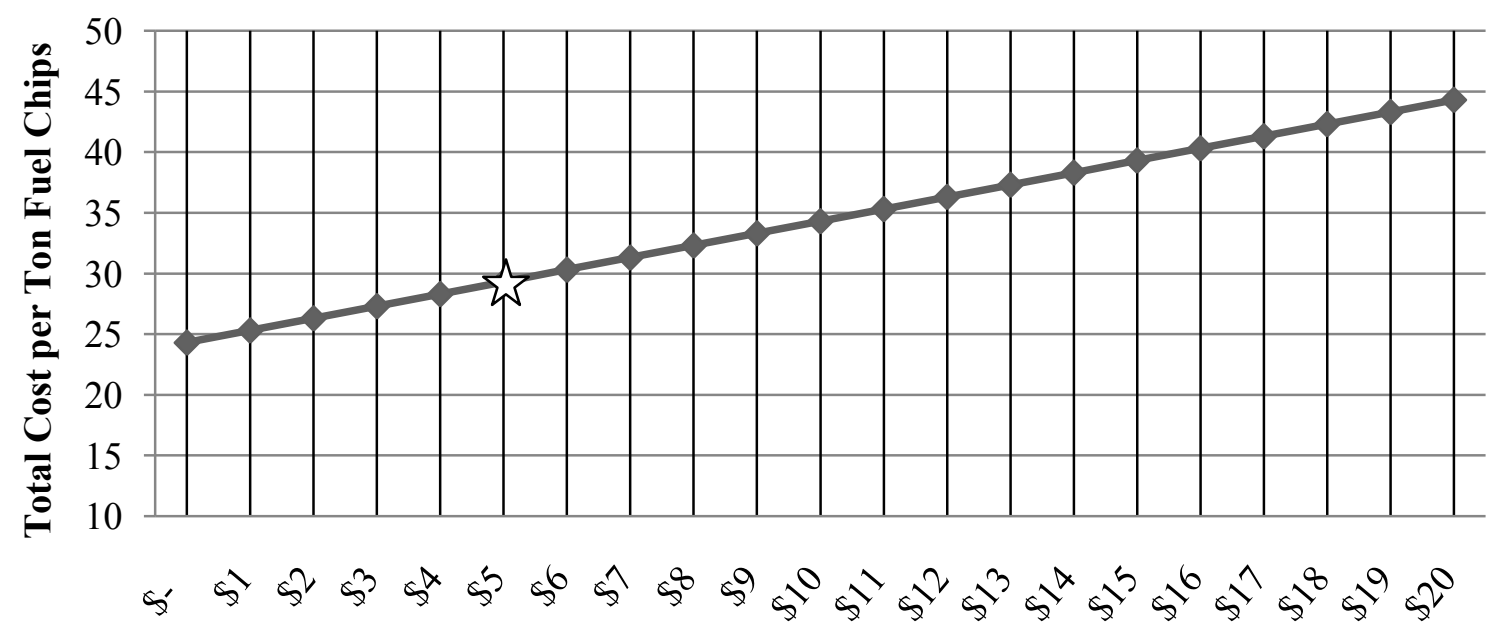

Fuel chips stumpage cost $\$ /$ ton

is Observed Fuel Chips Stumpage Cost

Figure 20. Sensitivity analysis of total production cost per ton to change to the stumpage cost paid for fuel chips. Other cost components held constant include harvesting, labor, and hauling. This analysis assumes a fuel price of $\$ 2.50$ per gallon of off-road diesel.

\subsubsection{Scenario \#5 Government Subsidy}

The 2008 Farm Bill included a biomass cost-share prevision called Biomass Crop Assistance Program (BCAP) that provides a price subsidy for woody biomass material. According to the Department of Agriculture Federal Register (2010) Volume 75, No 25., "BCAP is intended to assist agricultural and forest land owners and operators with the establishment and production of eligible crops including woody biomass in selected project areas for conversion to bioenergy, and the collection, harvest, storage, and transportation of eligible material for use in a biomass conversion facility" (Cook 2010). One of the policies programs is a "matching payment" that will match the price received 
per dry ton dollar for dollar up to $\$ 45.00$ dollars. This part of the policy aims to increase revenues from biomass harvests thus making more operations become economically feasible and therefore more biomass be delivered to energy conversion sites. If this program would have been utilized during this study harvest it would have based the price support on two things: the price paid at the pulp mill ( $\$ 26.00$ per ton) and conversion from green tons to dry tons (a 50 percent reduction in weight). The 50 percent conversion factor is cited by the Federal Register as the industrial standard to use to adjust for the moisture content (DOA 2010 p. 6265). Thus the $\$ 26.00$ per green ton price would be reduced by 50 percent to yield a matching payment of $\$ 13.00$ per green ton. The Federal Registry states that person(s) able to receive the payment are "persons who owns or have the authority to sell to the biomass facility". In this case, this person would be the forest operator who won the stumpage bid to gain the harvest rights of the study site. Assuming that all 18 loads of biomass were sold to Pulp mill \#1 and at $\$ 26.00$ per ton and the contract chip van hauler still received $\$ 12.00$ per ton, the additional subsidy payment would have elevated the price received from $\$ 26.00$ per ton to $\$ 39.00$ per ton. This additional payment changes the profit/loss from a $\$ 10.20$ loss to a $\$ 2.80$ profit per ton. Thus the overall profitability of the system is increased to $\$ 9,093.06$.

Adding a matching price support for fuel chips material will elevate prices received by forest operators. This action is not assumed to change the costs of operation but will make it more likely for the price received for the fuel chips to be greater than the cost to produce the fuel chips. Therefore, if BCAP enables more operators to receive prices greater than the cost of operation then it would be expected that more operators would collect fuel chips and overall more fuel chips would be harvested. If the stated 
objective of the BCAP program is to get more biomass (woody or otherwise) onto the market than this analysis would indicate that it would be successful.

Table 21. Balance sheet of integrated system with the BCAP matching subsidy added to the fuel chips.

\begin{tabular}{|l|c|c|}
\hline & SHWP & Fuel Chips \\
\hline Revenue /ton & $\$ 32.64$ & $\$ 39.00^{*}$ \\
\hline Harvest Cost per ton ( - ) & $\$ 11.17$ & $\$ 19.20$ \\
\hline Hauling cost per ton ( - ) & $\$ 4.21$ & $\$ 12.00$ \\
\hline Stumpage cost per ton $(-)$ & $\$ 9.95$ & $\$ 5.00$ \\
\hline Profit per Ton ( $)$ & $\$ 7.31$ & $\$ 2.80$ \\
\hline Total Tons ( $)$ & $1,066.66$ & 462.78 \\
\hline Profit/loss ( $)$ & $\$ 7,797.28$ & $\$ 1,295.78$ \\
\hline Grand Total Profit/loss (+) & \multicolumn{2}{|c|}{$\$ 9,093.06$} \\
\hline
\end{tabular}

*BCAP matching payment of $\$ 13.00$ per green ton is added to the delivered price of $\$ 26.00$ per green ton. The BCAP matches dollar for dollar on dry tons, thus a conversion (50 percent reduction) is applied yielding $\$ 13.00$ per green ton.

\subsection{Residual Damage Assessment}

Residual damage observed in this study harvest was considerable (Figure 21).

Overall, 25 percent of all residual stems were observed to have some level of damage. Within the different plots damaged varied between 9 percent and 34 percent. There was no significant difference at 0.05 percent confidence in the mean percent residual damage between the shelterwood strip and the single tree selection treatments (Table 22, Figure 22). However, the pooled single tree selection treatment and pooled shelterwood strip treatment appear to be different at a confidence level of 0.15 indicating that there may be some slight difference in damage between treatments. The average single tree selection residual damage was 27.1 percent of trees, while the average shelterwood strip residual damage was 22.8 percent. However, the strength of these comparisons is limited due to the low sample size. Further testing is needed to verify these trends. 


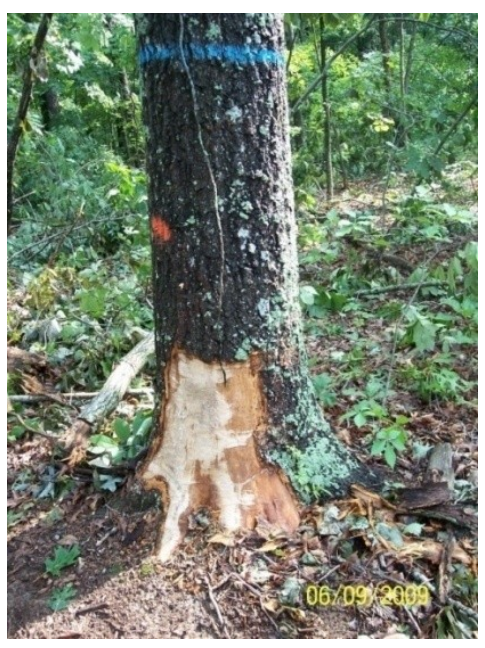

Figure 21. Marked leave tree that received skidding damage during harvest. An estimated 25 percent of residual trees in the harvested area experienced some kind of harvest damage.

Table 22. Mean comparison of residual damage between treatment designs.

\begin{tabular}{|c|c|}
\hline Comparison & $p$-value \\
\hline STS vs SW & 0.1356 \\
\hline STS vs SW75 & 0.2079 \\
\hline STS vs SW150 & 0.4932 \\
\hline SW75 vs SW 150 & 0.6476 \\
\hline
\end{tabular}

$\mathrm{STS}=$ Pooled single tree selection treatment

SW $=$ Pooled shelterwood strips

SW75 $=75$ foot wide shelterwood strip

SW150=150 foot wide shelterwood strip 


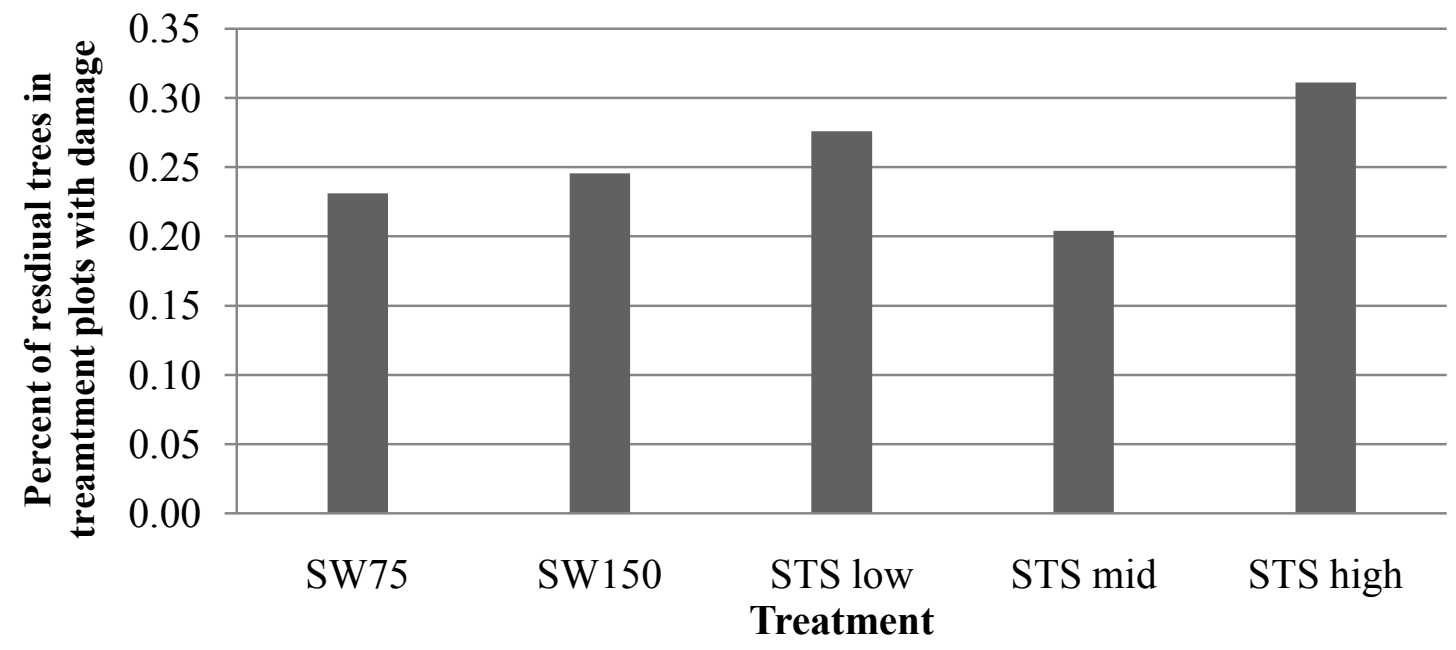

Figure 22. Average residual damage observed by treatment. No significant differences were detected between the treatment means.

The presence of damage was largely influenced by several key factors: tree length logging, spring harvesting, skid path layout, bumper tree placement, feller buncher felling damage, and others. The most notable was caused by skidding tree length logs. Tree length skidding required attention to several factors: trimming of major branches prior to skidding, using skid paths with straight line skids, making turns on skid path gradual, and finally, good placement of bumper trees that skidded logs can pivot on when making sharp corners. Anecdotal observations collected throughout the study harvest identified them as critical factors affecting residual damage. Reliable data on these three factors is not available, but show promise for future studies where residual damage is of great concern. One of the key objectives for the shelterwood strips was to route the skidder in more linear skid paths to reduce the number of turns (gradual and sharp) that the skidder would need to make. This dynamic was observed on occasion, but not enough to develop a significant difference between treatment designs. 


\section{Summary and Conclusions.}

The sections and subsections within the Summary and Conclusions synthesize study key findings, both quantitative and qualitative. Section 4.1 summarizes all the scenarios presented in Section 3 and discusses issues related to revenues and costs observed in the study. Section 4.2 discusses the macro economic factors that affect the prices observed. Finally, section 4.3 summarizes the factors that affected the operational efficiency and identify bottlenecks observed in the harvest system.

\subsection{Yields, Revenues, Costs, and Profits}

Economic feasibility evaluates processes to identify if the total costs are less than or equal to the revenues of the activities. This study harvest explored whether harvesting SHWP and fuel chips in the Missouri, Ozarks with a fully mechanized and integrated harvest system was a feasible operation under current market conditions. The subsections below summarizes the findings of this study.

\subsubsection{Yields and Revenues}

This study harvested two main products: SHWP and fuel chips. The SHWP accounted for the greatest share of revenue (77 percent) because a greater volume (70 percent) was harvested and secondly, it was sold at a higher per unit price. A total of 1,066.66 tons of SHWP were harvested from the 29.86 treated acres for an average of 35.72 tons per acre. A total of $38 \log$ trucks of SHWP were removed from the site (averaging 28.35 tons per truck) and were sold to seven different local sawmills. The average price received for SHWP was $\$ 32.64$ per ton but ranged from $\$ 14.00$ per ton to 
$\$ 81.10$ per ton. Total revenues from SHWP totaled $\$ 34,817.16$ dollars, equivalent to a per acre revenue of $\$ 1,166.01$ dollars.

Fuel chips comprised 30 percent of the total tonnage harvested and only 23 percent of the total revenue received. A total 462.78 tons were harvested from the 29.86 treated acres for an average of 15.50 tons per acre. A total of 18 chip vans of fuel chips were removed from the site (averaging 25.71 tons per truck) and were sold to two different fuel chips buyers. The average price received for fuel chips was $\$ 22.08$ per ton but ranged from $\$ 0.00$ per ton to $\$ 26.00$ per ton (one load of fuel chips was given away to a fuel chips buyer to offset very large hauling costs observed by the buyer). Total revenue from fuel chips sales amounted to $\$ 10,216.18$ dollars or a per acre revenue of $\$ 342.14$ dollars. Fifteen of the 18 chip vans were sold to the fuel chips buyer for $\$ 26.00$ per ton; however this price was shared with a contracted chip van hauler who received $\$ 12.00$ per ton for hauling services, thus the harvest operation only derived 14.00 per ton to cover harvesting and stumpage costs.

\subsubsection{Costs and Profits}

The main cost components were harvest costs, hauling costs, labor costs and stumpage costs. This study converted these costs into a 'per ton' format for easy comparison between components and to determine the total cost of production which is the breakeven price. A hypothetical harvest system called merchantable system was created to estimate the profit/loss the harvest if no efforts was made to harvest fuel chips and was compared with the observed integrated system (Table 23). 
Table 23. Comparison of the revenues, costs, and profit/loss of the Integrated and the Merchantable Harvest System.

\begin{tabular}{|l|c|c|c|}
\cline { 2 - 4 } \multicolumn{1}{c|}{} & \multicolumn{2}{|c|}{ Integrated System } & Merchantable System \\
\cline { 2 - 4 } & SHWP & Fuel Chips & SHWP \\
\hline Revenue /ton & $\$ 32.64$ & $\$ 26.00^{*}$ & $\$ 32.64$ \\
\hline Harvest Cost per ton ( - ) & $\$ 11.17$ & $\$ 19.20$ & $\$ 11.54$ \\
\hline Hauling cost per ton ( - ) & $\$ 4.21$ & $\$ 12.00$ & $\$ 4.21$ \\
\hline Stumpage cost per ton ( - ) & $\$ 9.95$ & $\$ 5.00$ & $\$ 9.95$ \\
\hline Profit per Ton ( $)$ & $\$ 7.31$ & $\$-10.20$ & $\$ 6.94$ \\
\hline Total Tons ( $*)$ & $1,066.66$ & 462.78 & $1,066.66$ \\
\hline Profit/loss $(=)$ & $\$ 7,797.28$ & $\$-4,720.36$ & $\$ 7,402.62$ \\
\hline Grand Total Profit/loss $(+)$ & \multicolumn{2}{|c|}{$\$ 3,076.92$} & $\$ 7,402.62$ \\
\hline
\end{tabular}

*The analysis assumed that all 18 loads of fuel chips were sold to the buyer giving $\$ 26.00$ per ton.

Five sensitivity analyses were completed to determine how changes in different input prices, hauling distances and the presence of a government subsidy affect the cost per ton. Fuel prices appeared to have the greatest affect on the cost per ton. It was observed that a $\$ 0.50$ change in fuel prices changed the cost of production per ton by \$0.69 and \$1.20 for the SHWP and fuel chips, respectively. Stumpage prices also greatly affected the production cost per ton and may be the most volatile of all the costs. Hauling distance played a critical role in the total cost per ton harvested. It is estimated that the cost per ton-mile is 0.0416 and 0.0459 for the SHWP and fuel chips respectively. Changes in the total equipment suite cost appeared to affect the cost per ton the least, but adds a considerable amount of risk to the operation by increasing the fixed cost of operation. The BCAP government matching subsidy would increase the price of fuel chips by an estimated $\$ 13.00$ per green ton. This additional revenue for the fuel chips 
would push price above the estimated breakeven point and yield a profit of $\$ 2.80$ per ton and a net profit of $\$ 1,295.78$.

Analysis showed that using the contract chip van hauler for $\$ 12.00$ per ton was more expensive than internalizing a chip van into the harvest equipment suite $(\$ 8.25$ per ton). The round trip hauling distance to the fuel chips buyer was approximately 180 miles. All of the sensitivity analysis scenarios assumed that the chip van was internalized into the equipment suite.

\subsubsection{Comparisons to other integrated harvests}

Puttock (1995) reviewed seven integrated harvest systems to estimate the cost of production for SHWP and fuel chips by each harvesting stage (Table 24). The cost of production for these observed systems appears to be comparable with the cost projections generated in this integrated harvest trial with a few exceptions (Table 25). The most notable discrepancy is that in this study the estimated costs for fuel chips were greater than the cost of SWHP, inconsistent with Puttock's estimations. This difference may be due to overestimation of the \%CHIPS figure. Puttock does not indicate how the costs were distributed between the two products. He only indicates that the costs "are apportioned between the conventional product the fuel wood according to the contribution of each product to total production". Four of the seven studies observed stumpage payments for the fuel chips, but their values were not reported. Furthermore, note that these figures have not been adjusted for inflation from 1995 to 2010 . 
Table 24. Cost estimates for seven integrated harvest systems complied by Puttock (1995). Cost estimates do not include stumpage or hauling costs. System estimates A-G not adjusted for inflation between 1995 and 2010.

\begin{tabular}{|c|c|c|c|c|c|c|c|}
\hline System & $\begin{array}{c}\text { Fuel } \\
\text { chips } \\
\text { as } \\
\text { \% of } \\
\text { total }\end{array}$ & $\begin{array}{c}\text { Felling/ } \\
\text { Skidding } \\
\text { SWHP }\end{array}$ & $\begin{array}{c}\text { Felling/ } \\
\text { Skidding } \\
\text { Fuel } \\
\text { chips }\end{array}$ & $\begin{array}{c}\text { Processing } \\
\text { /Sorting } \\
\text { SHWP }\end{array}$ & $\begin{array}{c}\text { Processing } \\
\text { /Sorting } \\
\text { Fuel chips }\end{array}$ & $\begin{array}{c}\text { Fuel chips } \\
\text { processing } \\
\text { method }\end{array}$ & $\begin{array}{c}\text { Fuel chips } \\
\text { processing }\end{array}$ \\
\hline A & 15 & $\$ 4.14$ & $\$ 0.77$ & $\$ 3.26$ & $\$ 0.61$ & Chipper & $\$ 6.88$ \\
\hline B & 33 & $\$ 3.93$ & $\$ 1.94$ & $\$ 6.46$ & $\$ 3.23$ & Chipper & $\$ 2.27$ \\
\hline C & 33 & $\$ 3.38$ & $\$ 1.69$ & $\$ 3.37$ & $\$ 1.79$ & $\begin{array}{c}\text { Tub } \\
\text { grinder }\end{array}$ & $\$ 3.26$ \\
\hline D & 57 & $\$ 19.64$ & $\$ 26.01$ & - & - & Chipper & $\$ 11.04$ \\
\hline E & 22 & $\$ 15.61$ & $\$ 4.40$ & $\$ 2.78$ & $\$ 0.78$ & Chipper & $\$ 3.26$ \\
\hline F & 40 & $\$ 21.05$ & $\$ 14.05$ & $\$ 9.19$ & $\$ 6.13$ & $\begin{array}{c}\text { Hammer- } \\
\text { mill }\end{array}$ & $\$ 1.50$ \\
\hline G & 100 & $\$ 0.00$ & $\$ 35.15$ & - & & Chipper & $\$ 12.76$ \\
\hline $\begin{array}{c}\text { This } \\
\text { study }\end{array}$ & 30 & $\$ 7.63$ & $\$ 8.11$ & $\$ 3.54$ & $\$ 4.28$ & Chipper & $\$ 6.81$ \\
\hline
\end{tabular}

Table 25. Total cost of production for solid hardwood products and fuel chips for seven integrated harvest systems. Cost estimates do not include stumpage or hauling costs. System estimates A-G not adjusted for inflation between 1995 and 2010.

\begin{tabular}{|c|c|c|}
\hline System & $\begin{array}{c}\text { Total cost to } \\
\text { deliver SWHP to } \\
\text { roadside }\end{array}$ & $\begin{array}{c}\text { Total cost to } \\
\text { deliver fuel chips } \\
\text { to roadside }\end{array}$ \\
\hline A & $\$ 7.40$ & $\$ 8.26$ \\
\hline B & $\$ 10.39$ & $\$ 7.44$ \\
\hline C & $\$ 6.95$ & $\$ 6.74$ \\
\hline D & $\$ 19.64$ & $\$ 37.05$ \\
\hline E & $\$ 18.39$ & $\$ 8.44$ \\
\hline F & $\$ 30.24$ & $\$ 21.68$ \\
\hline G & - & $\$ 47.91$ \\
\hline This study & $\$ 11.17$ & $\$ 19.20$ \\
\hline
\end{tabular}

Only one of sample studies (C) above occurred in the "Central United States" in a potentially hardwood stand, but no indication was made as to the species being harvested. All others occurred in Canada, the United Kingdom or Scandinavia in stands presumably 
composed of softwood species. Species data was not presented and can only be inferred based on the locations provided. Each of sample studies used different equipment suites to complete the integrated harvest. Again, sample study (C) has the most similar equipment suite of a feller-buncher and grapple skidder, but used a flail processing at the landing and a tub grinder to process the fuel chips.

O,Neal conducted a woody biomass harvest in the Missouri Ozarks in 2007. His harvest approach was not an integrated harvest. He did both a salvage harvest after a commercial harvest and a biomass harvest prior to a commercial harvest to gather and chip only small diameter material. His study estimated that a chip van could be filled for $\$ 17.31$ per ton, but speculates that equipment modifications could reduce this cost to $\$ 12.73$ per ton.

Becker(2006) also conducted an equipment trial in the Missouri Ozarks in 2006 testing several equipment suites. He observed a conventional chainsaw and skidder operation, a crawler skidder and feller buncher, and a harvester feller for forward extraction. These three systems were tested on three replicated 4 acre plots with a mixed oak and pine stocking. Production costs were presented in cost per cubic foot of material. After a conversion, it is as estimated to be $\$ 24.64$ for the conventional chainsaw-skidder system, $\$ 40.63$ for the feller buncher-crawler system, and $\$ 21.04$ for the harvesterforwarder. These systems did not run a chipper to generate fuel chips but did harvest pole sized stems that would have been chipped if an integrated system were utilized. 


\subsection{Factors that Influence Prices}

\subsubsection{Markets}

This study illustrated how unbalanced the fuel chips markets are in the Missouri, Ozarks. There were only two firms identified to buy fuel chips to in the region and neither is centrally located in the region. These sites were located approximately 88.0 and 198.1 miles away from the study site. These hauling distances result in very large hauling costs and thus less revenue for the operator. In the current market conditions it is not feasible to harvest fuel chips in the Missouri, Ozarks unless a better price is received or harvest and hauling costs can be significantly reduced.

A market with one or only a few buyers and many producers is called an oligopsony. Murray (1992) analyzed the market power of sawmills and pulpmills in the United States between 1958 and1988. He found that neither of these markets was truly competitive and the pulpwood markets were less competitive, more like an oligopsony, than the SHWP markets. In oligopsony markets, the mills (the buyers) know that the logger (producers) have only one or few options to sell their product, and thus the buyers can offer a low price for the product and the loggers have to take the price or else be stuck with a giant pile of fuel chips that they cannot sell. At one point the fuel chips buyer paying the operation $\$ 26.00$ per ton found out that the operation had previously been receiving only $\$ 5.00$ per ton. The buyer's response was that he was paying too much for the fuel chips material.

The development of more fuel chips buyers in the Missouri, Ozarks is absolutely critical to creating a feasible market for fuel chips. These buyers do not need to be the final users of the product but could simply be an 'aggregator' that processes the material 
by passing it though a screen to remove long skinny twigs that are hard to chip in the woods, thus adding value to the product. Furthermore, storing the material so that the moisture content falls will also add value to the product because dry wood will contain more heat value (BTUs) than moist wood. These aggregators could gain bargaining position against final stage biomass users if they can control a significant amount of the biomass resource in a given region. Controlling a sizeable amount of the raw material would create more balance between the buyers and sellers of the biomass material, and could result in an increase in the price per unit. This price increase would ultimately trickle down to the forest operator in terms of higher prices for the raw material delivered from the woods. However, it is possible that the increase in prices would be consumed by the aggregator leaving the forest operator in their current position, receiving low prices for fuel chips.

There are several large industries that use fuel chips as in input that aggregators could pit against each other in a biding competition and thus increase prices. One example would be marketing the fuel chips to confined animal feeding operations (CAFOs) needing a carbon source to mix with their nutrient rich manure affluent for composting purposes. This could become a very sizable market if the best management practices for manure treatment shifts from land application to composting. Another market that uses fuel chips is the landscaping industry. These two industries represent key competitors for the raw resources and could help increase market prices of fuel chips. Regardless of end user, developing supply contracts between producers and buyers have the potential to increase prices and give the producer the confidence to invest in equipment needed to meet the contracted volume. 


\subsubsection{Demand}

The growth in the interest in renewable energy generation has great potential for the development of demand in the fuel chips markets. The placement of new biomass utilization facilities could rapidly change the oligopolistic market into a more competitive one that pays higher prices for raw material. This demand may also spill over into facilities that are able to add value to the raw material through screening, storing and delivering the material to final users. According to discussion with industry analysts in Missouri, there are 2 to 3 new biomass utilization facilities announced to be built in Missouri in the coming years ${ }^{4}$. If all facilities are constructed and their demand projections are correct, it is estimated that there will be demand for about 450 thousand tons of biomass each year in the state of Missouri ${ }^{4}$. The specific location of these points of utilization will drastically affect what forested areas will receive the benefits of more market competition, some will receive no benefit and some will suddenly be under fierce competition for material. This dynamic is already beginning in Mid-Missouri with the construction of the 100,000 ton per year capacity co-generation plant at the University of Missouri-Columbia (www.cf.missouri.edu/energy/em_renewable/index.html). This site is too far away for much of the Ozarks region to directly benefit from the market but it is conceivable for aggregators, if well placed and efficiently run, to act as a bridge into the Ozark forested region and extend the feasible hauling distance for this material.

\subsubsection{The Role of Policy}

One factor that could increase the prices that forest operators receive for fuel chips is state or federal price supports. Currently in Missouri there is a $\$ 5.00$ per ton of

\footnotetext{
${ }^{4}$ Discussions with Missouri Extension Forester, Hank Stelzer. March 2010.
} 
biomass tax credit for material that is converted into cellulosic ethanol (RSMo 135.300311, "Wood Energy Tax Credit") (www.dnr.mo.gov/energy/deprograms.htm). Current data indicates that there has yet to be an operator that has utilized this subsidy, primarily due to the fact that there is not a cellulosic ethanol processing facility in the region that could purchase the material. This concept could however be applied to biomass that will be utilized for a more common energy platform like combustion.

The Food, Conservation, and Energy Act of 2008 included a provision for a matching price support for biomass material up to $\$ 45.00$ dollars per ton (FCEA 2008). Section 3.7.5 presented estimates for how this program would affect the profitability of this observed study harvest. Adding a matching subsidy to fuel chips material will increase the prices so that more forest operators will be able to sell the material for more than their cost of production. In this study harvest the price subsidy elevated the per unit price above the cost of production leading to a profit on the fuel chips harvesting efforts. Without a competitive fuel chips market with strong prices in the Ozarks, the feasibility of fuel chips harvesting will be limited, even with the BCAP production subsidy.

Price supports could be used as an incentive for compliance with a suite of Best Management Practices. For example, the State of Missouri could give forest operators a per ton payment for woody biomass if they meet a specific management criteria that leads to monitoring of harvest sites and better understanding of the chain of custody for the woody biomass material. These two pieces of data would provide assurance that best management practices are implemented more widely across the state and that loggers doing reckless harvest jobs are sanctioned appropriately. Such a program would add significant costs to the state budget in terms of subsidy payments and monitor costs need 
to inspect logging sites and track other logistics. The cost benefit analysis of such policy should be explored further.

Some states have implemented a "tag" system that requires all loggers to place a tag on the back of every load of logs and fuel chips that is sold in the state. These tags include specific information like the name of the logging operation, the location of the harvest site, and the mill being shipped to. The mill then completes the form by reporting the amount and type of material that is purchased. This data is then compiled to yield useful information on where logging operations are occurring, who is conducting them, and how much is being harvested. This provides the necessary information to complete follow up inspections and do landscape level modeling with Geographical Information System (GIS) software. This data would also be very useful for private investors or biomass users to track trends and identify opportunities.

\subsection{System Efficiency}

There are several key aspects that affect how efficient a system operates. This harvest system did not observe major equipment delays that can severally limit productivity (O’Neal 2007). However, system efficiency within the observed harvest suite could be improved through several steps. The subsections below will discuss how harvest flow logistics could limit bottlenecks in operation (4.3.1), how treatment design can affect efficiency (4.3.2) and how Best Management Practices factor into the equation (4.3.3.).

\subsubsection{System Efficiency: Bottlenecks}

The most notable system bottleneck observed in this study harvest was related to the availability of the chip van. Since the chip van was operated by a third party filling 
the van always took top priority when it arrived. This often occurred when the logging truck had just arrived a few minutes prior. In these cases the log truck left the landing to make room for the chip van to be filled.

In most cases the chip van would arrive when there was at least an entire load of fuel chips waiting to be chipped at the landing. This scenario is preferable because it reduces the amount of time that the chipper is in operation. Storing large amounts of fuel chips on site and quickly filling the chip van when it arrives is called a "cold deck" system and is preferable when there is strong time pressure placed on the chip van due to long hauling distances.

In scenarios where there is less time pressure on the chip van because it is internalized in the equipment suite or the hauling distance is short, the operation could practices a "hot deck" system and fill the chip van as material arrives to the landing. This creates a situation that at times could be more efficient. This system would be preferable when the skidder is bringing bundles of trees in at a rapid pace and thus the loader must operate at a higher rate to process the trees or else the landing would become too clogged with material to be sorted and stacks of SHWP logs and piles of small diameter material to be chipped. The loader would focus on filling the chip van only when it is caught up with processing bundles brought in by the skidder and can then fill the chip van during time that would have otherwise been down time. To facilitate this system well, the loader operator must have remote start and stop control over the chipper to reduce the amount of time that the chipper is running.

Another system bottleneck comes just after the feller buncher drops the trees. At this point a crew member follows up with a chain saw to cut the major branches off of the 
felled trees before the skidder arrives. This person's job was often a bottleneck because the feller buncher and skidder can both work much faster than the chain saw operator. Thus the skidder often had to wait for the crew member to delimb the trees in the woods. If the skidder operator picked up a tree prior to being delimbed then large branches would likely still be attached and it would be more likely to cause damage to residual trees as it is skidded to the landing. On occasion trees with large branches attached were skidded to the landing and caused handling problems for the loader. In these cases the chainsaw operator would delimb in the landing causing both the loader and the skidder to wait for the trees to be delimbed and the crew member to leave the landing. Thus, it is preferable to do all delimbing in the woods and not practice whole tree skidding. Furthermore, the skidder driver and chainsaw operator need to communicate well to make sure that all trees are delimbed prior to being skidded to the landing.

\subsubsection{System Efficiency: Treatment}

As discussed in the Methods section, one of the main objectives of this study was to test the effectiveness of harvest treatments and their affect on the harvest volumes per acre, harvest costs, and ecological impacts. Three treatments were tested in the study harvest: a single tree selection thinning that leaves a target residual basal area and shelterwood strips at two different widths, 75 and 150 feet, both stretching 450 feet in length.

Data to answer these questions produced mixed results. This study was able to determine that more material per acre was harvested from the single tree selection treatments than the shelterwood strips. The comparison of harvest volumes per acre becomes even more unbalanced when the buffers of the shelterwood strips are factored 
into the production per acre rates. There was only slight statistical difference in the amount of residual damage between treatment designs with the shelterwood strips having lower percentages of damage to residual trees. However, residual damage higher than the BMPs limits in all but one harvest plot. There was no statistically significant difference in the productivity rates in terms of harvest time per acre due to the high variability in harvest time caused by different operators and delays. There was no significant difference in the cost of harvesting between treatments either. The small sample size of plots limited the significance of these tests.

Discussions with the operators about the two systems indicated that the shelterwood strip design had several advantages. Foremost, the linear design for the harvest made it easier for the feller buncher and skidder to work together. The long linear strips made it easier for the skidder to find the felled trees and thus reduce the amount of time the skidder needed to drive around the site looking for trees. Another benefit is keeping the skid paths straight. The shelterwood strips at 75 feet wide appeared to be more effective at minimizing the number of turns made within the harvest plots.

In the future this design should be set up in a slightly different manner. Due to the data collection requirements of this study, the harvest plots were set up randomly without regard for where strips would be optimally placed, not the most realistic format for a timber harvest. In a non-research based harvest operation one should look for clear straight line paths along the contour of the slope to place the strips. The 75 foot strips appeared to be superior to the 150 foot strips because they could be harvested with just a single skid path rather than two for the 150 wide strips. All of these single skid paths ultimately come off a main skid trail that leads directly to the landing. The placement of 
a single skid path off of the main skid trail should be done adjacent to a bumper tree that would help the skidder pivot the logs to align them on the main skid trail. In this study harvest this turn was a 90 degree turn. Making this turn from the single skid path to the main skid trail a wider angle will make it easier to pivot trees and result in less residual damage.

The effects of this treatment on the regeneration and growth of the future stand are still yet to be determined because more data needs to be collected. However, it is hypothesized that shelterwood strips will result in several small openings that could be large enough to facilitate recruitment of a new cohort of trees into the over story. The probability of this occurring is a largely a function of the shade cast by the standing over story around the openings both in the harvested strip and by the buffers. In general, one could hypothesize that the 75 wide strips will have a lower probability of recruitment than the 150 foot wide strips and the 150 foot wide strips would have a lower probability than the 3 acre single tree selection areas because there is a less influence of the over story trees in the nearby un-harvested buffers. This assumption will be validated or disproven in the coming years as more data is collected.

One of the key advantages of the shelterwood strips is its aesthetic appearance from a distance. Due to the large buffers between the strips there were many residual trees left on the site. This practice reduces the visual signs that a harvest has occurred in the area and retains the aesthetic appeal of a closed canopy forest. Conversely, since the method leaves so many buffers on the land that it requires more acreage to yield the same volume of material and causes the operation to drive further to harvest the same amount 
of material adding to the cost of operation. The ecological benefits of leaving buffer strips to various wildlife species are largely unknown.

The strategy of the shelterwood strips is to reenter the site again after 10 to 15 years to harvest the leave trees from the initial harvest and thin the new cohort of trees to the dominant stems and select dominant stump spouts. During this reentry the buffer strips could also receive their first shelterwood thinning and set in motion the development of another new cohort. Ultimately, this treatment approach leads to an uneven age forest that can be treated on a periodic basis to harvest mature trees and small pole trees in pre-commercial thinning.

\subsection{Future Research}

Future research to build this study's findings is needed to better understand the economic feasibility of harvesting both SHWP and fuel chips. First, the study site was not representative of the majority of the Ozarks forest in the sense that the site had very limited slope. It would be useful for future economic feasibility harvests to occur on sites with a greater percent slope to better understand how this variable affects operational efficiency.

Secondly, operating in a younger overstocked dense stand would also be preferred. These sites are in the greatest need of management in Missouri due the effects of crowding on oak decline, and are difficult to harvest profitably because the average tree size is smaller and a very small percent of the revenues of the harvest will be derived from SHWP. A majority of volume will come from pole size tree between 3 and 8 inches at breast height ( 4.5 feet off the ground) that can be sold as fuel chips. 
Thirdly, the concept of arranging harvests in log narrow strips should be further explored. Future studies should experiment with doing a "banded strip" where the center 25 feet of the strip is cleared to facilitate a skid path and the adjacent 25 feet on either side is thinned to release intermediate trees into the over story. Furthermore, the order of pre-experiment setup should follow; identify landings, identify main skid trails, identify bumper trees for banded strips to pivot on, and then layout the long strips off of the main skid trail. Approaching the harvest in this manner makes it more difficult to replicate in the scientific method because the exact area of treated forest would not be uniform between strips and the area would not be known prior to harvest layout. However, this approach would be more similar to the thought process that a forester or logger would go through when planning out a timber harvest and thus be more useful to foresters and loggers wanting to utilize this harvest method for production purposes. 


\section{Literature Cited}

Ames, G.C.W. and Dunavent, B.B. 1984. Georgia's Wood Fuel Data Base: An integrated Information System for Biomass Energy User. Southern Journal of Applied Forestry. 8(1): 5-6, p. 64.

Arola, R.A., and Miyata, E.S. 1981. Harvesting Wood for Energy. USDA. FS. Research paper NC-200. 1981.

Becker, P., Jensen, J., and Meinert, D. 2006. Conventional and Mechanized Logging Compared for Ozark Hardwood Forest Thinning: Productivity, economics and Environmental Impact. Northern Journal of Applied Forestry. Vol 23, No 4, December 2006.

Beilmann, A. P. and L. G. Brenner. 1951. The Recent Intrusion of Forests in the Ozarks. Annals of the Missouri Botanical Garden. 38(3): p.261-282.

Berti, R.J. 1984. An Assessment of Biomass Harvesting on Small Woodlots in New Hampshire. New Hampshire Department of Resources and Economic Development, Division of Forests and Lands. June 1984.

Birch, T, 1996. Private Forestland Owners of the United States, 1994. Resource Bulletin NE-134. Radnor, PA : Forest Service, USDA, Northeastern Forest Experiment Station. 1996.

Bolding, C.M. 2002. Forest Fuel Reduction and Energywood Production Using a CTL/Small Chipper Harvesting System. Master thesis to Auburn University. 2002

Bolding, C.M., Kellogg, L.D., Davis, C.T. 2005. Soil Disturbance from an Integrated Mechanical Forest Fuel Reduction Operation in Southwest Oregon. Proceedings, $28^{\text {th }}$ Annual Council on Forest Engineering Meeting, July 11-14, 2005.

Bolding, C.M., Kellogg, L.D., Davis, C.T. 2006. A Productivity and Cost Comparison of Two Non-Commercial Forest Fuels Reduction Machines. Proceedings, $29^{\text {th }}$ Annual Council on Forest Engineering Meeting, July 30-August 2, 2006.

Bolding, C.M., Kellogg, L.D., Davis, C.T. 2009. Productivity and Costs of an Integrated Mechanical Forest Fuel Reduction Operation in Southwest Oregon. Forest Products Journal Vol. 59 No. 3 p35-46. 2009.

Bowman M. J. S, Balch, J.K., Artaxo P., Bond, W.J., Carlson, J.M., Cochrane, M.A., D’Antonio, C.M., DeFries, D.S., Doyle, J.C., Harrison, S.P., Johnston, F.H., Keeley, J.E., Krawchuk, M.A., Kull, C.A., Marston, J.M., Moritz, M.A., Prentice, I.C., Roos, C.I., Scott, A.C., Swetnam, T.W., Van der Werf, R.S. Pyne S.J., 2009. Fire in the Earth System. Science 324, 481 (2009); 
Brinker, R.W., Kinard, J., Rummer, B., Lanford, B., 1989. Machine Rates for Selected Forest Harvesting Machines. Alabama Agricultural Experiment Station. Auburn University, Original printing 1989, Reprint 2002.

Burns, R.M., B.H Honkala. 1990. Silvics of North America: Volume 2. Hardwoods United States Department of Agriculture (USDA), Forest Service, Agriculture Handbook 654. 1990.

Cook, J. and Beyea, J. 2000. Bioenergy in the United States: Progress and Possibilities. Biomass and Bioenergy Vol.18. p 441-455. 2000.

Cook, 2010. Department of Agriculture. Federal Register, Vol. 75. No. 25, February 8, 2010. 7 CFR Part 1450. Biomass Crop Assistance Program; Proposed Rule.

Cunningham, R.J. and Hauser C. 1989. The decline of the Missouri Ozark Forest Between 1880 and 1920. Proceedings of the pine-hardwood mixtures: A symposium on the management and ecology of the type. USFS, Gen. Tech. Rpt. 58, Atlanta, Georgia.

Dodds, K. J., and P. J. Smallidge. 1999. Composition, vegetation, and structural characteristics of a pre-settlement forest in western Maryland. Castanea 4:337-345.

Dwyer, J. P., J. M Kabrick. (2007). Do Improvement Harvests Mitigate Oak Decline in Missouri Ozark Forests? Northern Journal of Applied Forestry 24: 123-128.

Epplin, F.M. 1996. Cost to Produce and Deliver Switchgrass Biomass to an EthanolConversion Facility in the Southern Plains of the United States. Biomass and Bioenergy. Vol. 11. No. 6 p. 459-467. 1996

Evans, A.M. 2008. Synthesis of Knowledge from Woody Biomass Removal Case Studies. US Forest Service, Forest Guild. September 2008.

Evans, R.S. 1974. Energy Plantations_-Should We Grow Trees for Power Plant Fuel? Canadian Forest Service Western Forest Products Lab. Inf. Rep. VP-X-129, P.15.

Fan, Z. and J. M. Kabrick. 2008. Oak mortality associated with crown dieback and oak borer attack in the Ozark Highlands. Forest Ecology and Management. 255(7): p. 2297-2305. 2008.

FCEA 2008. Food, Conservation, and Energy Act of 2008 frwebgate.access.gpo.gov/cgibin/getdoc.cgi?dbname=110_cong_bills\&docid= f:h2419enr.txt.pdf. Last Accessed 426-10

Fink, R.J and Fink R.L. 2006. An Assessment of Biomass Feedstock Availability in Missouri. Report for the University of Missouri Office for Special Programs, Missouri 
Department of Natural Resources Energy Center, and Department of Energy/Southern States Energy Board.

Flader, S.L. 1999. History of Missouri Forests and Forest Conservation. "Toward Sustainability for Missouri Forests" NCRS Gen Tech Report NC-239.

Franklin, J. F., K. Cromack, Jr., W. Denson, A. McKee, C. Maser, J. Sedell, F. Swanson, and G. Juday. 1981. Ecological Characteristics of Old-Growth Douglas-Fir Forests. USDA, Forest Service Gen. Tech. Rep. PNW-118. 1981.

GAO. 1981, The Nation's Unused Wood Offers Vast Potential Energy and Product Benefits. Report EMD-81-6. GAO. Washington, D.C. 115 p.

Google Maps. http://maps.google.com. Last accessed 3-9-10.

Guyette, Richard P. and Cutter, Bruce E. 1991. Tree-ring analysis of fire history of a post oak savanna in the Missouri Ozarks. Natural Areas Journal. 11(2): 93-99.

Hagan, J. M., and S. L. Grove. 1999. Coarse woody debris. Journal of Forestry 97:6-11.

Hahn, J.T. and J.S. Spencer, 1991. Timber resource in Missouri, statistical report, 1989. Resour. Bull. NC-119. St. Paul, MN U.S. Department of Agriculture, Forest Service, North Central Forest Experiment Station. 123 p.

Harmon, M. E., J. F. Franklin, F.J. Swanson, J. P. Sollins. 1986. Ecology of coarse woody debris in temperate ecosystems. Advances in Ecological Research. Volume 15. Academic Press, New York, p. 133-302.

Howard, J.O. 1979. Wood for Energy in the Pacific Northwest: An Overview. USDA. FS. PNW For. And Rng Expt Stn. GTE PNW-94. Sept. 1979.

Janowiak M.K. and C.R. Webster. 2010. Promoting Ecological Sustainability in Woody Biomass Harvesting. Journal of Forestry. January/February 2010.

Kellogg, L.D., Spong, B. 2004. Production and Costs of Cut-To-Length Thinning: Experience from the Willamette Young Stand Project. Research Contribution 47, Forest Research laboratory, Oregon State University, Corvallis.

Kinetic Electronic Designs. (www.ked.co.za) Last accessed 3-9-10.

Koch, P., 1980. Harvesting energy chips from forest residues - some concepts from the southern pine region. USDA. FS. Gen. Tech. Rpt. CO-33, 24 p. 1980.

Krusekopf, H.H. 1963. Forest Soil Areas in the Ozark Region of Missouri. Missouri Agriculture Experiment Station Bulletin 818. 1963. 
McMinn, J.W. and D.A. Crossley. 1993. Biodiversity and Coarse Woody Debris in Southern Forests. USDA Southern Research Station, Athens GA.

Missouri Department of Conservation. 2008. Missouri Woody Biomass Harvesting Best Management Practices Manual. Missouri Department of Conservation, Jefferson City, MO.

Missouri Department of Conservation, April-June 2009. Missouri Department of Conservation, Forestry Division. Missouri Timber Price Trends. Volume 19, Number 2.

Missouri Department of Natural Resources, Energy Center, August 2009. Missouri Energy Bulletin.

Mitchell, C.P., A.V Bridgewater, D.J. Stevens, A.J. Toft, M.P. Watters. 1995. Technoeconomic Assessment of Biomass to Energy. Biomass and Bioenergy, Vol 9. No. 1-5, p. 205-226, 1995.

Mitchell, D. and Gallagher, T. 2007. Chipping Whole Trees for Fuel Chips: A Production Study. Southern Journal of Applied Forestry Vol. 31 No. 4. p.176-180. 2007.

Miyata E.S. 1980. Determining Fixed and Operating Costs of Logging Equipment. USDA Forest Service. North Central Forest Experimentation Station, St.Paul. MN.

Monahan, R.T. and Wartluft, JL.1980. Prospectus: Firewood Manufacturing and Marketing. USDA. FS. NA-FR-17. February, 1980.

Moser, K.W., M.H. Hansen, T. Treiman, B. Moltzan, R. Lawrence, G.J. Brand. 2004. Missouri's Forest Resources in 2004. Resource Bulletin NC-257. St. Paul, MN. USDA, North Central Research Station. 2004

Nigh, T.A. 1999. Missouri’s Forest Resources- An Ecological Perspective. Toward Sustainability for Missouri Forests. Gen. Tech. Report NC-239 USDA, Forest Service, North Central Research Station. 6 p.

Olsen, E.D. and Kellogg L.D. 1983. Comparison of time-study techniques for evaluating logging production. T. ASAE. 26(6) p. 1665-1668.

O’Neal, B. 2007. Preliminary results, unpublished.

Puttock G.D. 1995. Estimating Cost for Integrated Harvesting and Related Forest Management Activities. Biomass and Bioenergy Vol. 8 No 2. P. 73-79. 1995.

Pyne, S.J. 1982. Fire in America: a Cultural History of Wildfire and Rural Fire. Princeton, NJ: Princeton University Press. 654p. 
Samuelsson, J., L. Gustafsson, and T. Ingelog. 1994. Dying and dead trees: a review of their importance for biodiversity. Swedish Threatened Species Unit. Uppsala. 1994.

SAS Institute, Inc., SAS v. 9.2. 2008. Cary, North Carolina, U.S.A.

Sauer, C.O. 1920. The Geography of the Ozark Highland. The Scientific Monthly. 11:215-227.

Shifley, S.R. 1999. Missouri's Timber Resources: Finding a Sustainable Balance Among Growth, Harvest, and Consumption. Toward Sustainability for Missouri Forests. Gen. Tech. Report NC-239. USDA, Forest Service, North Central Research Station. 84 p.

Spencer, J.S., Essex, B.L. 1976. Timber in Missouri, 1972. Resource Bulletin NC-30. St. Paul, MN. USDA, Forest Service, North Central Forest Experiment Station 108 p.

Spinelli, R., R.J.M Visser. 2009. Analyzing and estimating delays in wood chipping operations. Biomass and Bioenergy. Vol. 22. p. 429-433. 2009.

Stambaugh, M.C. 2001. Forest Canopy Gap Dynamics in Shortleaf Pine Forests of the Ozark Highlands. Master Thesis, University of Missouri. 2001

Steyermark, J. A. 1940. Study of the Vegetation of Missouri-I National Plant Associations and Succession in the Ozarks of Missouri. Botanical Series, Field Museum of Natural History IX(5).

Stokes, B.J., D.L. Sirois. 1986. Evaluation of Chipper-Forwarder Biomass Harvesting Concept. USDA, Forest Service Southern Forest Experiment Station, Proceedings, 1986.

Stokes, B.J., Sirois, D.L., Watson, W.F. 1989. Recovery of Forest Residues in the Southern United States. International Energy Agency Symposium, "Harvesting Small Trees and Forest Residues". Auburn University, AL. June 5-7, 1989.

Sturos J.A., Barron R.M., Miyata, E.S., Steinhilb, H.M. 1983. The Economics of a Mechanized Multiproduct Harvesting System for Stand Conversation of Northern Hardwoods. USDA. FS. Research Paper NC-237. 1983

University of Missouri, Energy Management. www.cf.missouri.edu/energy/em_renewable/index. Last Accessed April 252010.

Updegraff, K., M.N. Baughman, S.J. Taff. 2004. Environmental Benefits of Cropland Conversion to Hybrid Poplar: Economic and Policy Considerations. Biomass and Bioenergy Vol. 27. p.411-428. 2004.

USDA, Forest Service. www.srs.fs.usda.gov/forestops/download.htm Last accessed 3-910. "Download of the Ground Based General Harvesting Model" 
USFS. 2004. Fuels Planning: Science Synthesis and Integration. RMRS-RN-19WWW, U.S. Forest Service, Rocky Mountain Research Station, Fort Collins, CO.

U.S. Energy Information Administration. 2009. Renewable Energy Production and Consumption by primary Energy Source, 1949-2008. Online at http://www.eia.doe.gov/emeu/aer/renew.html Accessed on Feb. 24, 2010

Wright L., B. Boundy, P.C. Badger, B. Perlack, S. Davis. 2009. Biomass Energy Data book: Edition 2. Oak Ridge National Laboratory. Prepared for DOE April 2009.

Yoshioka, T., Aruga, K., Nitami, T., Hideo, S., and Kobayashi, H. 2006. A Case Study on the Costs and the Fuel Consumption of Harvesting, Transporting, and Chipping Chains for Logging Residues in Japan. Biomass and Bioenergy. Vol.30, 2006 p. 342-348.

Zerbe, J.I. 1982. Energy Properties of Wood. Proceedings, Fuelwood management and Utilization Seminar. The Kellogg Center for Continuing Education Michigan State University. East Lansing, Michigan. November 9-11, 1982 


\section{Appendix A: Study summary using seven themes identified by Evans (2008)}

The section below uses the analytical framework used by Evans to put this study into perspective. Only one other study in his analysis was conducted in Missouri and X utilized similar harvest equipment.

\section{Objectives:}

The silvicultural objectives of the study were to remove low value trees, improve growth of residual trees, and create growing space for a new cohort of trees to grow. This will transition stand from even-age to a two age stand. Red and black oaks near the end of their physiological lifespan were favored for removal to capture the economic value of mature. The trees selected as leave trees were primarily in the white oak group that will continue to grow for many years, thus replicating late successional forest conditions of wide spaced mature trees. Furthermore this study aimed to test the Woody Biomass Best Management Practices (WBMPs) recommended by the Missouri Forest Resources Council (MOFRC) (MDC 2008).

\section{Collaboration:}

A partnership between the Missouri Department of Conservation (MDC) (land owner), University of Missouri (foresters/researchers), and private contractors (loggers) was created for this study harvest. Multiple sources of funding were utilized for this project. Funding for researchers came from the Missouri Small Business Development Association (MSBDA). MDC contributed staff time to monitor the logging job and subsidized the operation by accepting a below market value stumpage price that reduced the risk taken on by the contracted logging operation. 


\section{Ecology:}

Biomass Harvesting Guidelines recommended by MDC were utilized during the study harvest. Planning meeting between the landowner, forester/researcher, and logger occurred throughout the study harvest to make sure that compliance with the WBMPs was maintained. Efforts focused on retaining adequate slash levels on the site (30\%), leaving snags and cull trees for wildlife benefits (6 per acre), placement of water bars on skid trails and monitoring/reduction of damage to residual trees (less than 10\%).

\section{Fire:}

Even though the Ozarks were historically a fire dominated ecosystem, fire and the discussion of reestablishing historic fire regimes played no role in this study.

\section{Economics:}

Multiple products, solid hardwood products (SHWP) and fuel chips, were harvested in this study. The higher priced SHWP made up about 70 percent of the tonnage removed and over 84 percent of the project revenue. This revenue was able to offset the observed economic losses associated with harvesting low value fuel chips. Given that that leaving the slash does not pose a significant fire risk but rather provides an ecological benefit to the future productivity of the site, it is not economically justified to make addition efforts/expenses to harvest and haul the fuel chips material. Only if fuel chips prices increase through market competition or public subsidy will the additional cost be offset and lead to a profitable scenario.

The region has very week fuel chips markets with a large imbalance of power between buyers (power plants or aggregators) and sellers (loggers). Thus product prices 
can be set by the buyers at levels below the breakeven points needed by the sellers. Fluctuations in buyer demand add variability to the fuel chips market. The expended increasing demand for energy feedstock represents a market opportunity for loggers if the competition for the material can increase prices to levels high enough for the logging operator to breakeven. This study estimates that these prices need to be at least 24 dollars per ton.

\section{Implementation:}

A mechanized equipment suite (feller buncher, grapple skidder, knuckleboom loader, and chipper at landing) was utilized to conduct the study harvest. Equipment was larger than the traditional equipment utilized in the region. This resulted in high productivity but in high operation cost. The harvest design removed forest material in a single pass "integrated" approach that removed SHWP and fuel chips at the same time. Whole tree skidding was done to reduce the number of skidding cycles needed to bring the material to the landing to be processed by a knuckleboom loader. Major branches were removed by hand prior to skidding and were left in the woods. The chipper processed small diameter suppressed/intermediate trees, tops of trees brought in by skidder below merchantable diameter limits, and short length large diameter logs that were bucked at the landing to meet merchantability specifications (i.e. a 15 foot log bucked into a 12 foot log for SHWP will have a 3 foot log at landing).

The logging operation utilized a contact chip van hauler to deliver fuel chips to the chip mills. The contract hauler received $\$ 12$ of the $\$ 26$ dollars per ton received at the gate for the fuel chips. Economic estimation indicates that a greater return could be realized by the logging operation if they internalized the hauling of the fuel chips. 


\section{Regional Differences:}

The study harvest occurred on a mature mixed hardwoods stand that was able to sustain a commercial thinning operation. There were relatively low amounts of submerchantable size class material on the site as compared to other stands in the region in more dire need of stand improvements to reduce stand density and salvage trees suffering from oak decline.

Ozark sites typically have lower fertility when compared to rest of the eastern hardwood forests. This is primarily due to shallow soil prone to drought stress, and past management that has created overstocked stand conditions.

Private landowners hold over 83 percent of the forest land in Missouri (Hahn and Spencer 1991). Citizen participation in forest land management on public lands in Missouri rarely occurs ex ante (before the treatment), but has occurred after harvesting in public lands in the past. Many citizen conservation groups raised concern over large harvests on public lands in the 1990s that supplied material to a high capacity chip mill. It is expected that public interest in harvesting will increase in the future if more harvesting is conducted on public lands. Active inclusion of stakeholders is needed to avoid contentious backlash to harvesting and to engage the citizens in the debate about establishing a local energy supply from a renewable source. 


\section{Appendix B: Missouri Forest Resources}

The Missouri forest resource base stretches over a diverse landscape of rolling to steep hills, ridge tops, river bottoms and unique geological formations. As a result of this variation, a wide range of vegetation communities occur in a relatively small region. This diversity is a function of soil characteristics, moisture conditions, and geological terrain variations present as well as management over the past 6 to 12 decades (Steyermark, 1940). Dominant over story species include red oaks, white oaks, sugar maple, hickory and pine in various abundances while under story species include dogwood, sassafras, elm, black gum, ash, maple, huckleberry, deerberry, farkleberry, and many others (Steyermark, 1940, Moser et al. 2004).

The Ozark region makes up the southern half of Missouri and extends down into the northern part of Arkansas. The Ozarks are on the western end of the Eastern Broadleaved Forest Province where decreasing rainfall to the west supports primarily grasslands and increasing rainfall to the east supports primarily deciduous forests (Nigh, 1999). The area is primarily composed of steep hills resulting in a diversity of slope positions and soil characteristics, generally considered to be of limited fertility (Krusekopf, 1963). A vast majority of these hills were clear cut during the westward expansion between 1880 and 1920 (Beilmann, and Brenner 1951, Cunningham and Hauser, 1989). Forest stands prior to harvesting were thought to be composed of very large and wide spaced "park like" white oaks, short leaf pines, and hickories with a thick stand of grasses as a ground cover (Steyermark, 1940). After extensive harvests slowed in the 1920s, land was sold by lumber companies as real estate and parceled into small pieces for private landowners settling the west (Cunningham and Hauser, 1989). The private ownership that was established then remains today where 83 percent (11.1million 
acres) of Missouri forest land is owned by an estimated 307,000 private land owners (Hahn and Spencer 1991, Shifley 1999, Birch 1996). The Ozarks, especially upland areas, were then subjected to overgrazing from hogs and cattle for many years (Flader 1999). Open grazing damaged ground cover species and resulted in the reduction and eradication of young pines, many grasses and forbs species from parts of the Ozarks (Sauer 1920, Steyermark, 1940). Substantial amounts of dendrochronological evidence indicate that the Ozarks during pre-settlement times was a fire dominated ecosystem with fire intervals in some areas as frequent as every 4.3 years (Guyette and Cutter 1991). Natural fire regimes were altered through settlers' attempts to improve live stock forage by burning (Pyne 1982) and then aggressive fire suppression efforts which began in 1924 under provisions of the Clark McNary Act (Stambaugh 2001). Suppressing fire changed the growing condition for the plants reestablishing the sites after logging and thus favored fire intolerant species like oaks, hickories, maples, elms and cedars rather than the fire adapted pine and grass mixture observed by early explorers (Beilmann and Brenner, 1951).

As a result of past land management activities the much of the Ozarks regenerated into thick stands of red oaks, black oaks, white oaks and hickory (Steyermark, 1940, Cunningham and Hauser, 1989, Fink 2006). Volume estimates for Missouri between 2000 and 2004 are upwards of 18.5 billion cubic feet of live trees (Moser et al. 2004). Inventories in 1972 estimated there was approximately 9 billion cubic feet of live trees (Spencer and Essex, 1976). Today stands of second growth generally range in age from 120 to 80 years old. Stand stocking rates (spacing density) are thought to be higher than what is considered ideal to yield vigorous trees with potential to be harvested for fine 
hardwood products (Fink, 2006). Trees that have poor vigor are more predisposed to suffer from oak decline and are less likely to reach their full physiological life (Dwyer et. al, 2007, Fan et. al 2008). Red and black oaks (Quercus coccinea, Quercus falcata.var. falcata, and Quercus velutina) have been observed to have a physiological lifespan of between 65 and 110 years in the Ozarks, shorter for the competing hickories (Cayra spp.) and white oaks (Quercus alba, stellata) which are observed to live for upwards of 200 years. For all of these over story species, the life spans are lower than the species' observed maximum longevity primarily due to limiting environmental conditions such as poor soil, drought conditions, and overstocking present in the Ozarks. Table 26 shows the expected age ranges of the dominant tree species found in the Ozarks. Age estimates were adapted from Silvics of North America and discussion with Missouri foresters (Burns and Honkala 1990).

Table 26. Over story species observed in study site and estimated lifespan in the Missouri, Ozarks environment.

\begin{tabular}{|l|c|}
\hline \multicolumn{1}{|c|}{ Species (scientific name) } & $\begin{array}{c}\text { Expected physiological } \\
\text { lifespan in the Ozarks* }\end{array}$ \\
\hline White oak (Quercus alba) & $200+$ years \\
\hline Post oak (Quercus stellata) & $200+$ years \\
\hline Scarlet oak (Quercus coccinea) & $80-100$ years \\
\hline Black oak (Quercus velutina & $65-90$ years \\
\hline Southern red oak (Quercus falcata. & $80-110$ years \\
\hline Mockernut hickory (Carya tomentosa) & $200+$ years \\
\hline Sassafras (Sassafras albidum) & $20-50$ years \\
\hline
\end{tabular}

*Ages estimated based on discussions with foresters in the region. The actual lifespan of any tree is highly influenced by the local site environmental conditions and competition received from neighboring trees.

Harvesting and utilizing selected species near the end of their lifespan, before they lose value or succumb to natural mortality, is one of the driving forces that adds to the urgency of bringing Missouri Ozarks forest stands into active management(Fan et al. 
2008). Otherwise, these trees will lose all short term economic value and return to the soil through decomposition. Many ecologists have noted the importance dead and dying trees to a diverse and functioning ecosystem (Franklin et al 1981, Samuelsson et al 1994, Dodds et al. 1999). Snags (standing dead) and cull (hollow) trees provide habitat for many forest wildlife species as do downed trees for micro and macro fauna and nutrient needs of the residual stand (Harmon et al 1986,McMinn et. al, 1993, Hagen 1999). A recent inventory of the Missouri forests estimated that 2.6 billion cubic feet or 14.3 percent of all live trees are cull trees and thus are dead or dying (Moser et al. 2004). This trend is expected to continue or even increase in the future as more trees reach the end of their lifespan for the environmental conditions. 


\section{Appendix C: Sample Yellow Activity Monitoring System data sheet}

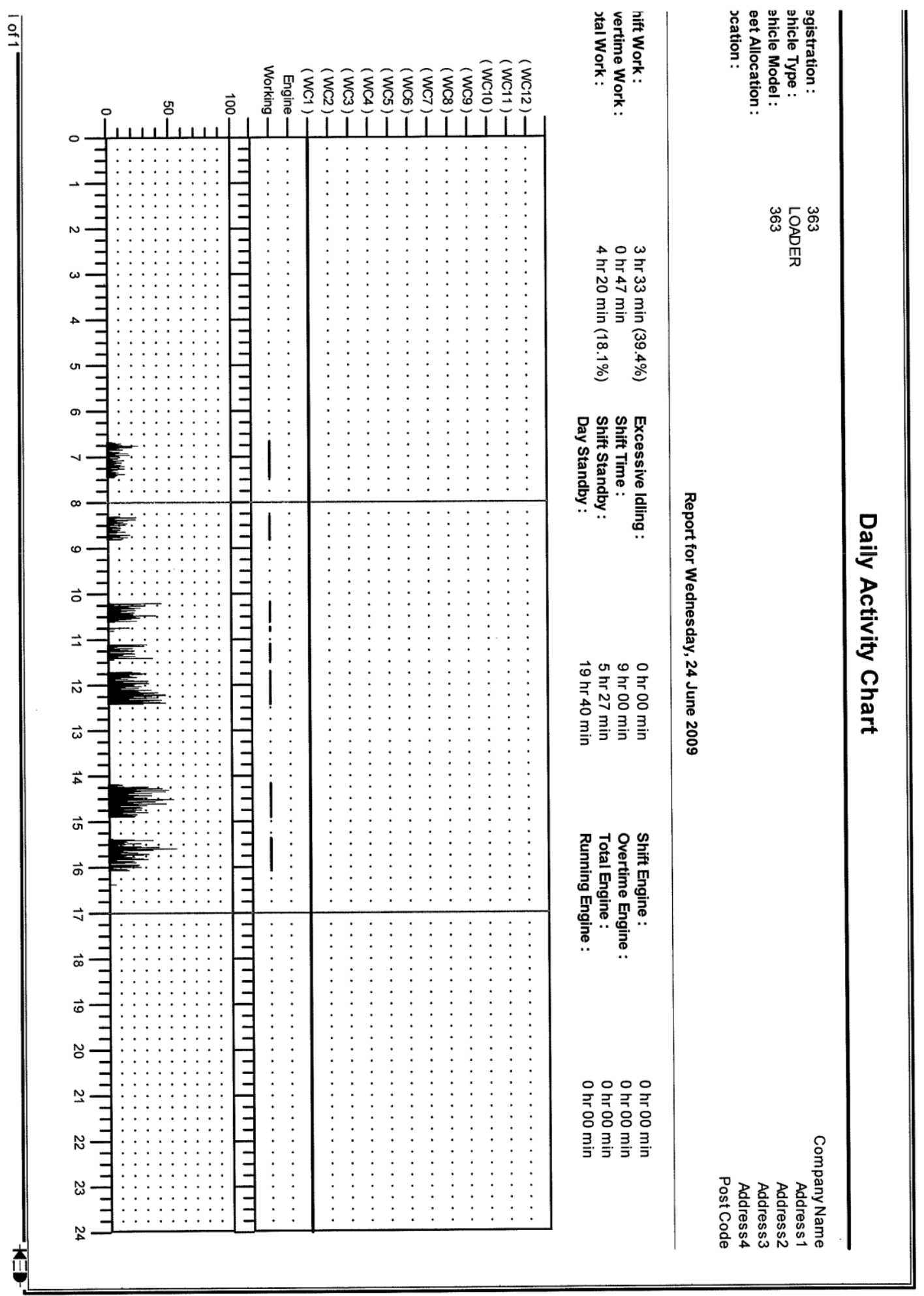




\section{Appendix D: Skidder Cycle time regression analysis and data sheet \\ D.1 Skidding Productivity}

Over the course of the harvest the Yellow Box time in motion data collectors recorded that the skidder was in operation for a total of 91.3 $\mathrm{PMH}$ or an average of 3.06 PMH per acre. Of all the harvest equipment the skidder was in operation the most. In fact, this figure indicates that this machine is a bottleneck of the harvest system. In terms of tons per PMH the skidder hauled 16.9 tons per PMH. When broken down per plot the $\mathrm{PMH}$ per acre varied between from under 1.8 $\mathrm{PMH} /$ acre to $3.8 \mathrm{PMH} / \mathrm{acre}$. As seen in Table 14 cost of owning and operating the skidder through this study harvest was $\$ 3,408.36$. This figure breaks down to $\$ 114.14$ per acre, $\$ 1.71 /$ ton SHWP and $\$ 3.42 /$ ton pulp assuming a \%pulp figure of 46 percent. These cost figures will be put into perspective with the other components in section 3.5 .

Three main sources were identified to cause variation in skidding productivity. The best quantified in this study was hauling distances and delays. The third was the use of the skidder to do work not directly related to dragging bundles of logs to the landing. These activities included building water bars along skid paths, clearing a site for a landing, assisting the loader in processing piles of fuel chips or assisting in the felling of large trees with strong side-lean. Spending time on these activities reduce the overall efficiency of dragging in logs, but are a requirement to follow harvesting best management practices and cannot be done by any other equipment.

One-way skidding distances from the landing to the felled trees ranged from 60 feet to 2,353 feet with the average skid being 950 feet (Figure 23). Skid cycle time 
ranged from 1 minute to 48 minutes. Frequency of one-way skidding distances appeared to not be evenly distributed (Figure 24).

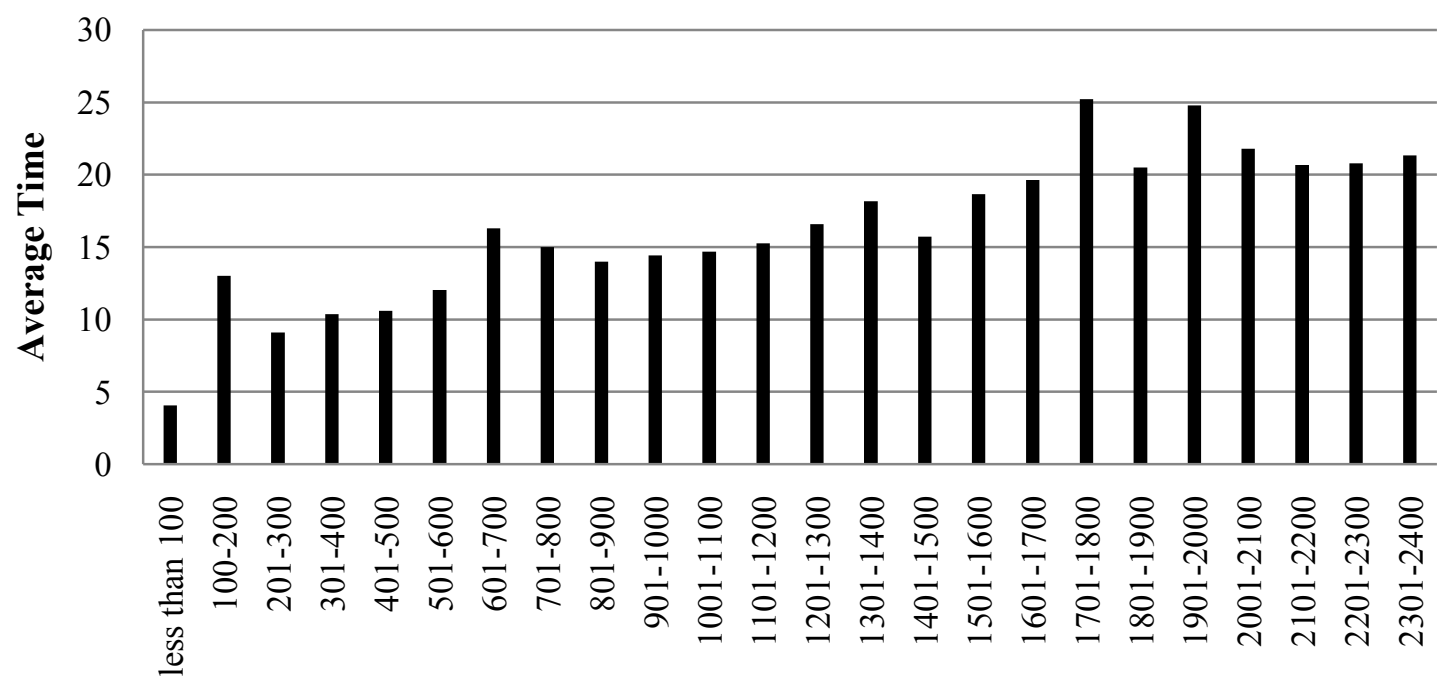

Skid Distance (ft)

Figure 23. Average cycle times for different observed skid distances between 60 feet and 2,353 feet.

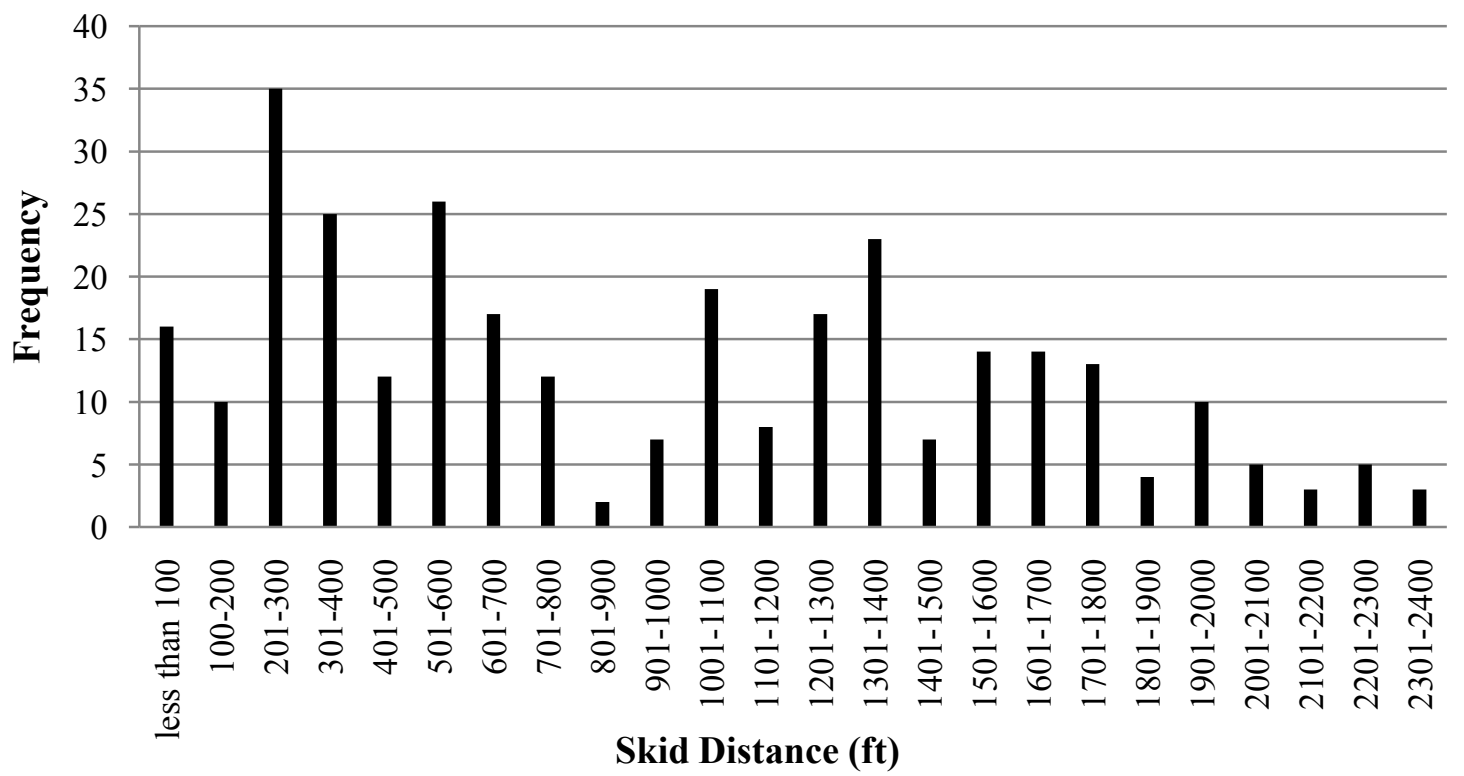

Figure 24. Frequency of skid distances observed during study harvest. 


\section{D.2 Skidder Productivity Regression Analysis}

A linear regression production function for the skidder was created to provide greater insight into the production dynamics of the skidder (Bolding 2009). Cycle time in minutes of each skid was used as the dependent variable and one-way distance in feet and presence of a delay were used as the independent variables. Distance is a continuous variable measured in 1,000 s of feet and delay is a binomial variable with yes/no observations $(0=$ no delay , $1=$ delay $)$. Models were fit with variables that indicate number of stems per skidder bundle and the percentage of the load made up of fuel chips, but these variables were not significantly helpful in predicting cycle time. Unlike the feller buncher, operator could not be used as a predictive variable since only one operator utilized the skidder throughout the study harvest. Equation 11 shows the regression equation used in this analysis and the results of the model are presented in Table 15. The model was able to explain about 48 percent of the variation in the data collected. All parameters had positive signs as expected. The b0, intercept, term was estimated to be 5.750 which implies that the minimum skid cycle time if distance was zero and no delays were observed. The b1, distance, term was estimated to be 7.575 meaning that every 1,000 of one-way skidding distance would add about 7.575 minutes to the skidding cycle time. The b2, delay, term was estimated to be 7.473 , meaning that if a delay was observed for any given skid, it would add about 7.473 minutes to the skid cycle time. This implies that the average skidder delay is about 7.5 minutes long.

Equation 1: $\quad$ CycleTime $=b 0+b 1 *$ Distance $+b 2 *$ Delay + error 
Table 27. Parameter Estimates for skidder regression analysis. Three parameters (intercept, distance, and delay) were observed to be significant in predicting cycle time.

\begin{tabular}{|c|c|c|c|c|}
\hline Variable & $\begin{array}{c}\text { Parameter } \\
\text { Estimate }\end{array}$ & Standard Error & t-value & P-value \\
\hline Intercept (b0) & 5.750 & 0.616 & 9.33 & $<0.0001$ \\
\hline $\begin{array}{c}\text { Distance (1000 feet) } \\
\text { (b1) }\end{array}$ & 7.575 & 0.522 & 14.51 & $<0.0001$ \\
\hline Delay (b2) & 7.473 & 0.744 & 10.04 & $<0.0001$ \\
\hline
\end{tabular}

$\mathrm{R}^{2}=0.48$, F-value $=153.59, \mathrm{RMSE}=5.97, \mathrm{p}$-value $=<.0001, \mathrm{n}=342$

The presence of skidding delays added considerable amount of time to skidding cycle times. Delays were observed on 25 percent of all the skid cycles and varied between 1 minute and 30 minutes. Delays can occur in several parts of the skidding cycle. At the landing the skidder would often need to push piles of small diameter material waiting to be chipped out of the main path prior to bringing new bundles into the landing. Fuel chips would accumulate where the loader's delimbing and top trimming would occur because this area is outside the reach of the loader arm. This pile would often obstruct the movement of the skidder. In the woods, the skidder would have to wait for both the feller buncher to complete cutting and a crew member to remove the major branches with a chainsaw before it could safely operate in an area. In the most efficient scenario, the feller buncher, chainsaw delimbing and skidder would all be operating at equal rates and at staggered distances apart so they would not interfere with each other. 